\title{
Subsurface Flow and Water Yield From Watersheds Tributary to Eagle Valley Hydrographic Area, West-Central Nevada
}

By Douglas K. Maurer and David L. Berger

Water-Resources Investigations Report 97-4191

Prepared in cooperation with the CARSON CITY UTILITIES DEPARTMENT and the WASHOE TRIBE OF NEVADA AND CALIFORNIA 


\title{
U.S. DEPARTMENT OF THE INTERIOR BRUCE BABBITT, Secretary
}

\author{
U.S. GEOLOGICAL SURVEY \\ MARK SCHAEFER, Acting Director
}

Any use of trade names in this publication is for descriptive purposes

only and does not constitute endorsement by the U.S. Government

For additional information

write to:

District Chief

U.S. Geological Survey

333 West Nye Lane, Room 203

Carson City, NV 89706-0866

email: usgsinfo_nv@usgs.gov

http://wwwnv.wr.usgs.gov
Copies of this report can be purchased from:

U.S. Geological Survey

Branch of Information Services

Box 25286

Denver, CO 80225-0286 


\section{CONTENTS}

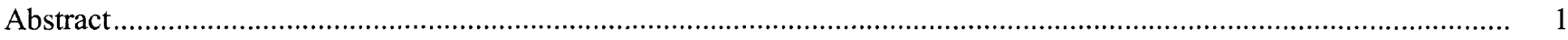

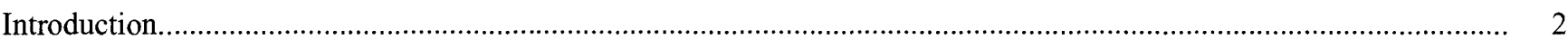

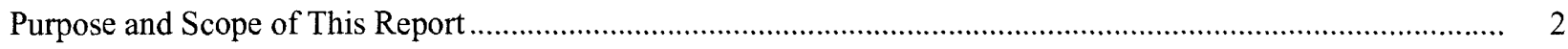

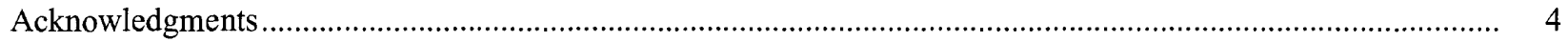

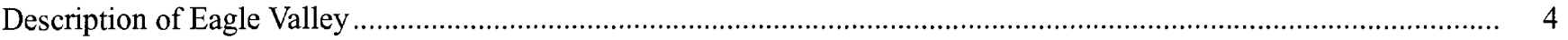

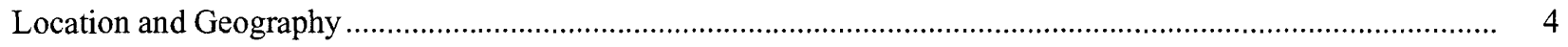

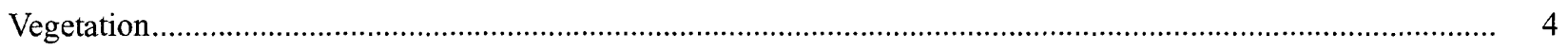

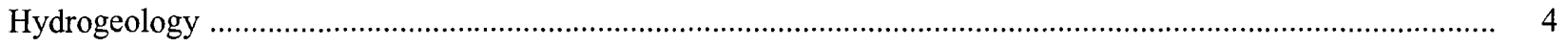

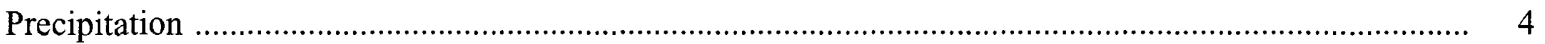

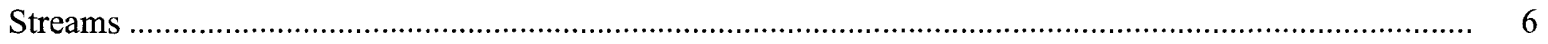

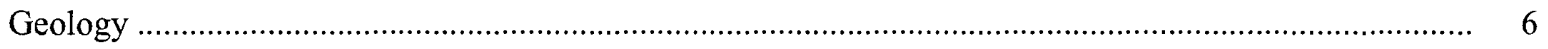

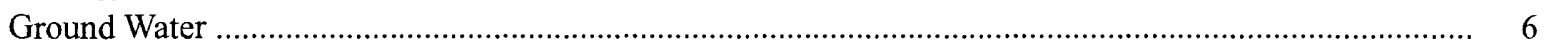

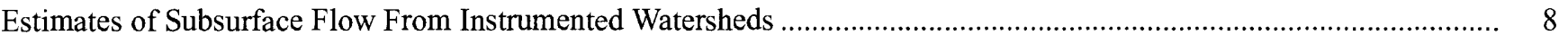

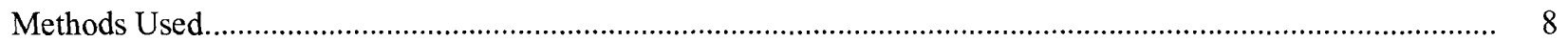

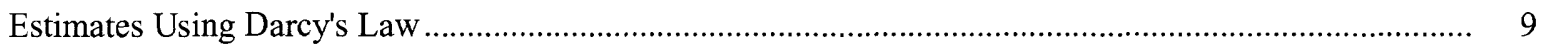

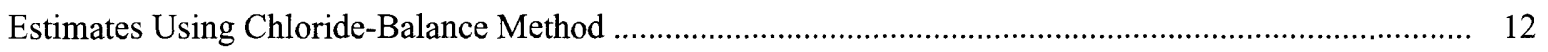

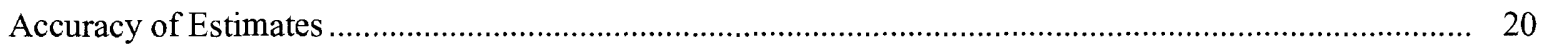

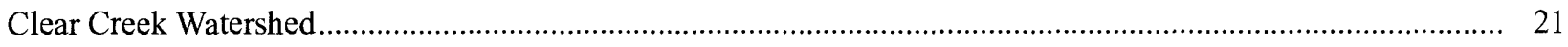

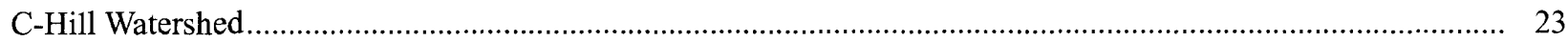

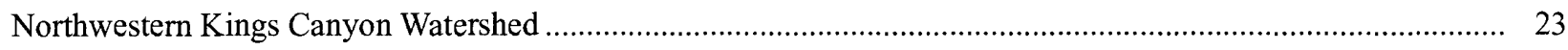

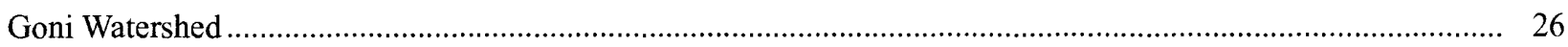

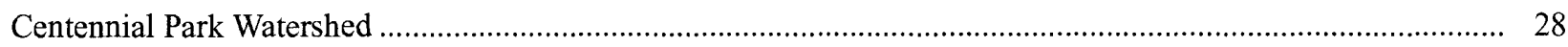

Estimates of Subsurface Flow From Uninstrumented Watersheds.................................................................... 30

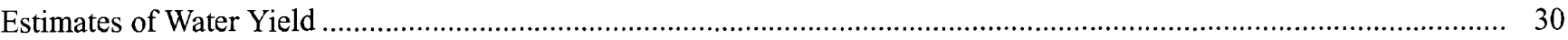

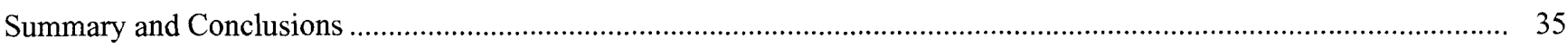

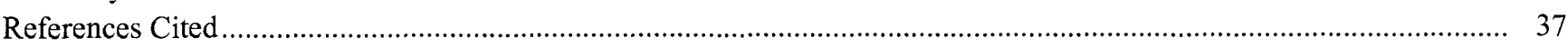

Appendix 1. Borehole Geophysical and Lithologic Data ................................................................................. 39

Appendix 2. Well Location, Construction, and Water-Level Data ......................................................................... 47

\section{FIGURES}

1-3. Maps of Eagle Valley Hydrographic Area showing:

1. Geographic features, area boundary, and tributary watersheds ........................................................... 3

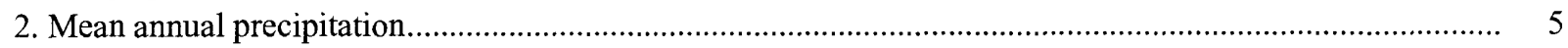

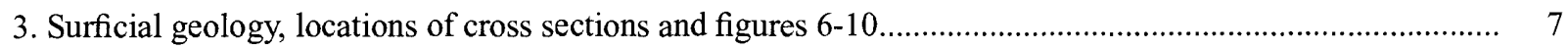

4-5. Graphs showing for test holes in Clear Creek, C-Hill, Kings Canyon, and Goni watersheds:

4. Relation between hydraulic conductivity determined from slug tests of wells and formation factor determined from resistivity of basin-fill sediments, bedrock, and ground water................................. 10

5. Distribution of hydraulic conductivity calculated from normal resistivity $\operatorname{logs}$........................................... 13

6-10. Maps showing surficial geology, location of wells and cross sections, and direction of subsurface flow and downslope water-table gradient; and cross sections showing distribution of saturated and unsaturated basin-fill sediments and bedrock for watersheds:

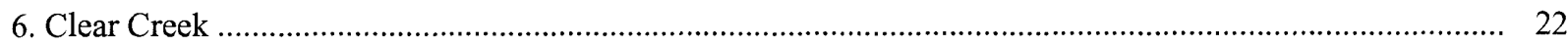

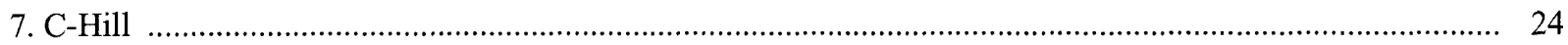

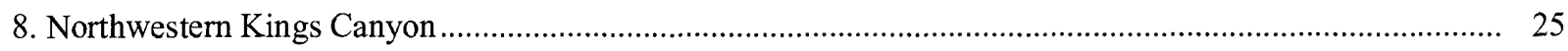

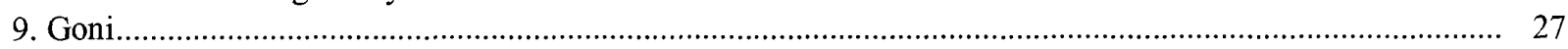

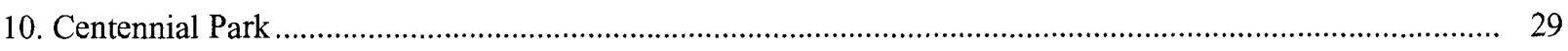

11. Graph showing relation between mean annual water yield and mean annual surface runoff to mean precipitation .. 35 


\section{TABLES}

1. Comparison of formation factor determined from resistivity of basin-fill sediments, bedrock, and ground water to average hydraulic conductivity determined from slug tests of selected wells in instrumented watersheds

2. Equations and statistical results derived from linear regression analysis used to describe relation between hydraulic conductivity and formation factor in selected instrumented watersheds

3-4. Geometric-mean hydraulic conductivity and thickness of hydrogeologic units beneath instrumented watersheds of:

3. Basin-fill sediments

4. Bedrock

5-6. Estimates of subsurface flow beneath instrumented watersheds at cross sections using:

5. Darcy's law

6. Chloride-balance method

7. Summary of subsurface-flow estimates for instrumented watersheds

8. Estimates of mean annual precipitation, subsurface flow, surface runoff, and water yield for tributary watersheds .. 32

9. Watershed area and mean annual precipitation, surface runoff, and water yield for instrumented watersheds.

\section{CONVERSION FACTORS, VERTICAL DATUM, and WATER-QUALITY UNITS}

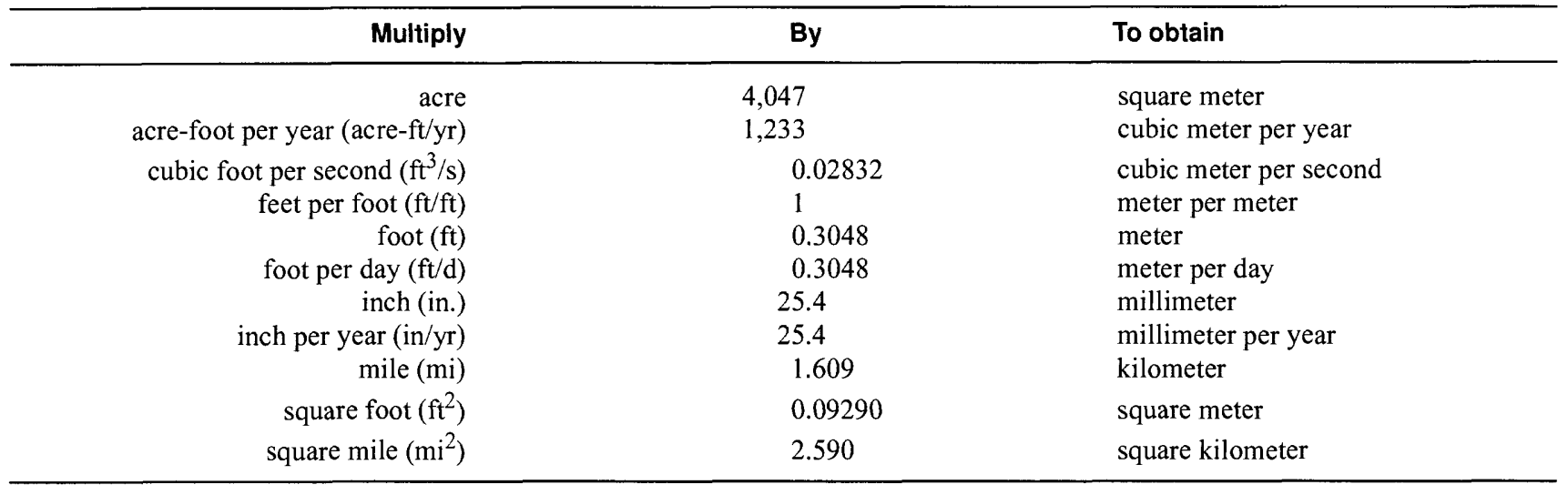

Sea level: In this report, "sea level" refers to the National Geodetic Vertical Datum of 1929 (NGVD of 1929, formerly called "Sea-Level Datum of 1929"), which is derived from a general adjustment of the first-order leveling networks of the United States and Canada.

Concentrations of chemical constituents in water are given in milligrams per liter $(\mathrm{mg} / \mathrm{L})$. 


\title{
Subsurface Flow and Water Yield From Watersheds Tributary to Eagle Valley Hydrographic Area, West-Central Nevada
}

\author{
By Douglas K. Maurer and David L. Berger
}

\section{Abstract}

In 1996, the U.S. Geological Survey began the second phase of a study to estimate subsurface flow and water yield from all watersheds tributary to Eagle Valley. For this study, test holes were drilled and wells installed along cross sections near the mouths of five watersheds, informally named Clear Creek, C-Hill, northwestern Kings Canyon, Goni, and Centennial Park. Data from the test holes and wells were used to estimate subsurface flow from the watersheds. The flow was calculated by Darcy's law from the hydraulic gradient across the section and the distribution, saturated thickness, and geometric-mean hydraulic conductivity of basin-fill sediments and bedrock beneath the section. The dissolved-chloride concentrations of precipitation, ground water, and surface water were used to provide an independent estimate of subsurface flow using the chloride-balance method. Previously, the U.S. Geological Survey made estimates of subsurface flow from Vicee, Ash, and southeastern Kings Canyons on the western side of Eagle Valley using the same methods. The percentage of annual precipitation represented by the range in subsurface-flow estimates for the eight instrumented watersheds was used to estimate subsurface flow from nearby watersheds tributary to Eagle Valley with similar geology.

The estimate of subsurface flow from all watersheds tributary to Eagle Valley ranges from 3,200 to 6,100 acre-feet per year (acre-ft/yr), equivalent to a continuous flow of 4 to 8 cubic feet per second at the perimeter of the valley floor. The chloride-balance method was not used for the Clear Creek watershed where road salt is applied on a highway during winter months. Subsurface flow estimated using Darcy's law was 1,200 acre$\mathrm{ft} / \mathrm{yr}$. This estimate could be low if more ground water flows (1) across the southern watershed/ hydrographic-area boundary or (2) at depths greater than that assumed permeable to flow beneath the cross section. For other instrumented watersheds, estimates of subsurface flow using Darcy's law and the chloride-balance method are from 20 to 70 acre- $\mathrm{ft} / \mathrm{yr}$ for the C-Hill watershed, from 600 to 2,300 acre-ft/yr for the southeastern Kings Canyon watershed, from 20 to 150 acre$\mathrm{ft} / \mathrm{yr}$ for the northwestern Kings Canyon watershed, from 200 to 500 acre- $\mathrm{ft} / \mathrm{yr}$ for the Ash Canyon watershed, from 300 to 400 acre-ft/yr for the Vicee Canyon watershed, from 70 to 400 acre-ft/yr for the Goni watershed, and from 20 to 30 acre-ft/yr for the Centennial Park watershed. Regressions of water yield for instrumented watersheds suggest that the low estimate of subsurface flow for southeastern Kings Canyon is the most reasonable value. The high estimate is based on Darcy's law, with a large volume of flow estimated through metamorphic rocks with open fractures. Drilling for this study has shown that metamorphic rocks with open fractures are probably limited in extent.

Runoff measured by gaging stations for four watersheds and runoff estimated from other watersheds was combined with subsurface-flow estimates to obtain water-yield estimates. The estimate of water yield from all watersheds tributary to Eagle Valley ranges from 12,000 to 15,000 acre$\mathrm{ft} / \mathrm{yr}$; greater than a previous estimate of 9,000 acre-ft/yr. The previous estimate considered 
subsurface flow to be minimal, and was more representative of runoff alone. The estimates of water yield range from 21 to 27 percent of annual precipitation. This suggests that 73-79 percent of precipitation in the watersheds is lost to evaporation and transpiration.

The annual volume of precipitation, surface runoff, and water yield estimated for each instrumented watershed was divided by the area of each watershed to obtain mean rates in inches per year. Mean water yield and runoff for each watershed were regressed against mean precipitation to develop equations predicting water yield and runoff in Eagle Valley with $r^{2}$ values of 0.93 and 0.91 , respectively. Additional estimates of water yield and runoff from nearby hydrographic areas would allow refinement of these equations, which might then be applied to other areas along the eastern slope of the Sierra Nevada.

\section{INTRODUCTION}

The growing population of Carson City, the capital of Nevada, is increasing the demand for municipal water. Up to 80 percent of the water supply for Carson City is from the basin-fill aquifers beneath Eagle Valley (Dorothy Timian-Palmer, Carson City Utilities Department, oral commun., 1994). Statepermitted pumping of ground water in Eagle Valley is about 8,400 acre-ft/yr (Matt Dillon, Nevada Division of Water Resources, written commun., 1994), of which about 6,700 acre-ft/yr is allocated to the Carson City municipal supply.

The basin-fill aquifer in Eagle Valley (fig. 1) is naturally recharged by subsurface flow from the adjacent mountains, by infiltration beneath streams as they flow across the valley, and possibly by infiltration of precipitation falling on the valley floor. Recharge to the Eagle Valley Hydrographic Area ${ }^{1}$ was previously estimated by Worts and Malmberg (1966, p. 15) using the

\footnotetext{
${ }^{1}$ Formal hydrographic areas in Nevada were delineated systematically by the U.S. Geological Survey and Nevada Division of Water Resources in the late 1960's (Rush, 1968; Cardinalli and others, 1968) for scientific and administrative purposes. The official hydrographic-area names, numbers, and geographic boundaries continue to be used in Geological Survey scientific reports and Division of Water Resources administrative activities.
}

Maxey-Eakin method (an empirical relation between precipitation and recharge) and by Arteaga and Durbin (1979, p. 14) using an estimate of water yield (subsurface flow plus surface-water runoff) from watersheds tributary to Eagle Valley. The accuracy of both estimates is uncertain because the first estimate was based on an empirical method developed for basins in eastern Nevada (Worts and Malmberg, 1966, p. 14), and the second used estimates of water yield that were based on assumed properties of bedrock underlying the watersheds (Arteaga and Durbin, 1979, p. 15 and 22).

In 1994, the U.S. Geological Survey, in cooperation with Carson City Utilities Department, began a study to refine estimates of ground-water recharge to Eagle Valley. The initial phase of the study used physical measurements of aquifer properties and applied Darcy's law and the chloride-balance method to estimate subsurface flow beneath three canyons on the western side of Eagle Valley-Vicee, Ash, and the southeastern part of Kings Canyons (fig. 1). Maurer and others (1996) determined that bedrock underlying these three watersheds was permeable to ground-water flow and that subsurface flow beneath the watersheds and total water yield from these watersheds were greater than previously estimated.

A second phase of study began in 1996 with the U.S. Geological Survey working in cooperation with Carson City Utilities Department and the Washoe Tribe of Nevada and California. The purpose of the second phase was to collect data from five additional watersheds tributary to Eagle Valley, estimate subsurface flow and water yield from all watersheds tributary to Eagle Valley, and to estimate ground-water recharge on the valley floor. This report presents only the resulting estimates of subsurface flow and water yield.

\section{Purpose and Scope of This Report}

The purpose of this report is to present estimates of subsurface flow and water yield from watersheds tributary to Eagle Valley, which can be used by water planners. This report describes hydrologic data collected from May to July 1996 beneath watersheds (fig. 1) instrumented at Clear Creek (watershed 2), near C-Hill (watershed 6), at northwestern Kings Canyon (watershed 11), near Goni Road (watersheds 20 and 21), and near Centennial Park (watershed 24). The watersheds were previously delineated and numbered by Arteaga and Durbin (1979, p. 16). 


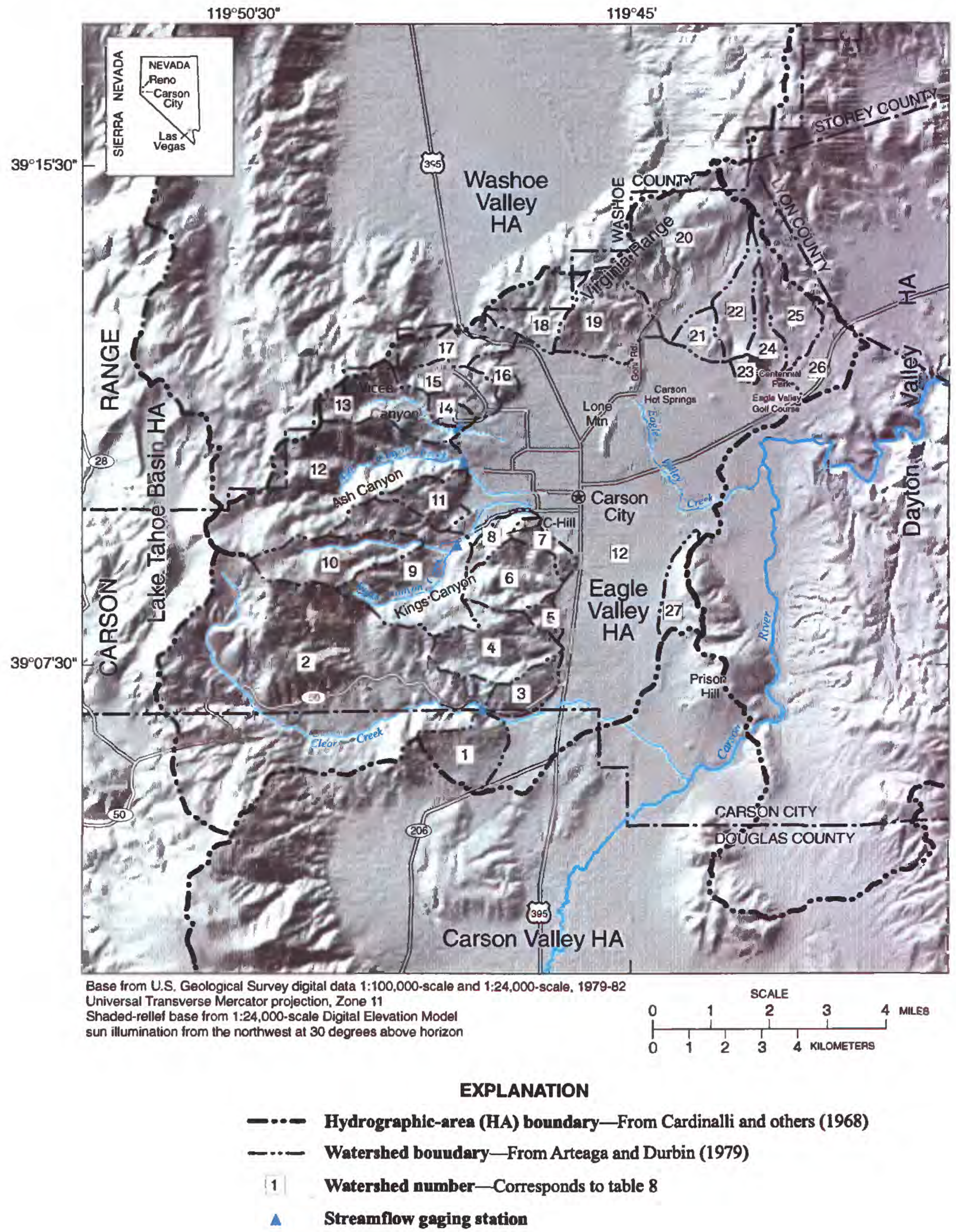

Figure 1. Geographic features, Eagle Valley Hydrographic Area, and watersheds tributary to Eagle Valley, Carson City, Nevada. 
Hydrologic data were collected from test holes and wells installed near the mouth of each of the five instrumented watersheds, including lithology and thickness of hydrogeologic units, depth to water, electrical resistivity, hydraulic conductivity, hydraulic gradient, and dissolved-chloride concentration of surface and ground water. From these data, subsurface flow from each instrumented watershed was estimated by applying Darcy's law as described by Maurer and others (1996, p. 10-11) using the cross-sectional area of each hydrogeologic unit, its geometric-mean hydraulic conductivity, and the measured hydraulic (water-table) gradient. Flow beneath each watershed also was estimated from dissolved-chloride concentrations of precipitation, ground water, and surface water, using the chloride-balance method described by Dettinger (1989).

A map of mean annual precipitation (fig. 2) developed by Arteaga and Durbin $(1979$, p. 16), was used to calculate the percentage of precipitation represented by the estimate of subsurface flow from each instrumented watershed. The resulting percentage for selected watersheds was used to estimate subsurface flow from uninstrumented watersheds by applying the percentage to nearby watersheds with similar geology. Water yield from each watershed was estimated by adding the estimate of subsurface flow to the measured or estimated surface-water runoff from each watershed. The resulting estimates of water yield are compared with those determined by Arteaga and Durbin (1979, p. 14).

The annual volume of precipitation, surface runoff, and water yield estimated for each instrumented watershed was divided by the area of the watershed to obtain mean values independent of watershed area. The mean amount of water yield and runoff for each watershed was regressed against mean precipitation to develop equations predicting water yield and runoff in Eagle Valley.

\section{Acknowledgments}

The authors thank Dennis Gebhardt of the Washoe Tribe of Nevada and California for aid in obtaining access to, and information about, Washoe Tribal lands; Dorothy Timian-Palmer, Charles Welch, and many others of Carson City Utilities Department for access to City rights-of-way, support of drilling operations, and data collection; and the Goni Preservation League for access to their land for installation of test holes.

\section{DESCRIPTION OF EAGLE VALLEY}

\section{Location and Geography}

Eagle Valley is a roughly circular basin about $6 \mathrm{mi}$ across with a total area of about $70 \mathrm{mi}^{2}$ (Worts and Malmberg, 1966, p. 2). The valley is bounded on the west by the Carson Range of the Sierra Nevada, on the north by the Virginia Range, on the east by low-lying Prison Hill and the flood plain of the Carson River, and on the south by Carson Valley (fig. 1). The floor of Eagle Valley is about 4,700 ft above sea level, the top of Prison Hill is about 5,700 ft, the Virginia Range is about $8,000 \mathrm{ft}$, and the Carson Range is higher than 9,200 ft. The Eagle Valley Hydrographic Area is largely in Carson City, Nev., ${ }^{1}$ however, small areas on the northern end of the area are in Washoe County, and the southernmost third of the Clear Creek watershed and all of watershed 1 are in Douglas County (fig. 1).

\section{Vegetation}

In Eagle Valley, the natural vegetation of sagebrush, rabbitbrush, bitterbrush, and grassy meadows on the valley floor has been replaced largely by houses, streets, and lawns. In 1965, Worts and Malmberg (1966, p. 24) estimated that 700 acres of native grass and alfalfa were irrigated with streamflow from Ash and Kings Canyons. In 1997, those irrigated fields also were being replaced by development. Vegetation in the Carson Range is primarily sagebrush, manzanita, and Jeffery pine, whereas vegetation in the Virginia Range and near the top of Prison Hill is primarily sagebrush, juniper, and pinon pine.

\section{Hydrogeology}

\section{Precipitation}

The floor of Eagle Valley lies in the rain shadow of the Sierra Nevada. Average annual precipitation estimated by Arteaga and Durbin (1979, p. 16) is about 10 in. on the valley floor, more than 38 in. along the crest of the Carson Range, and as much as 16 in. near the crest of the Virginia Range (fig. 2). Most precipitation

\footnotetext{
${ }^{1}$ Carson City is a political entity similar to Washington, D.C. Carson City is sometimes referred to as a county as well as the capital of Nevada. To avoid confusion, Carson City will be used hereafter only when referring to the city.
} 


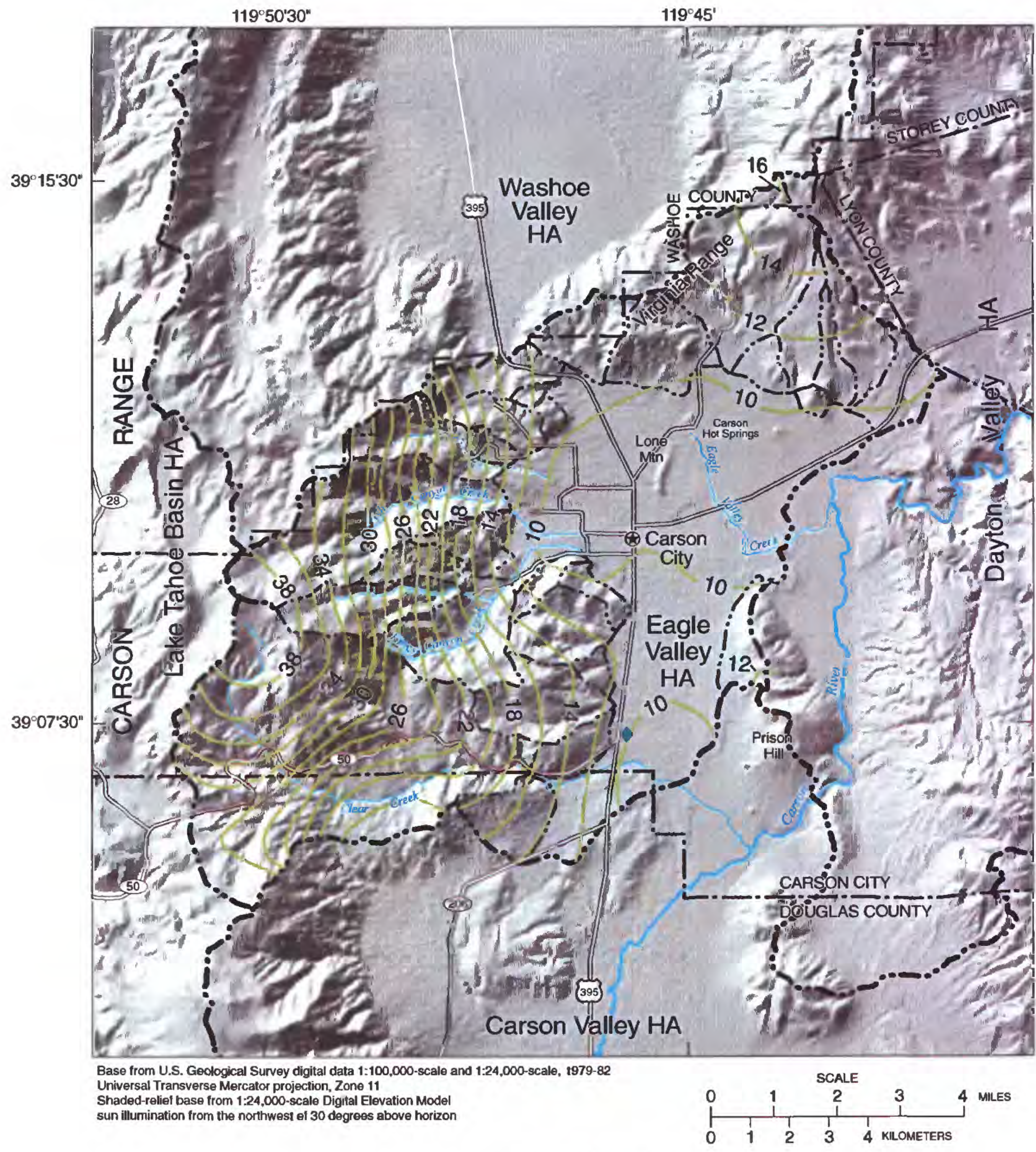

\section{EXPLANATION}

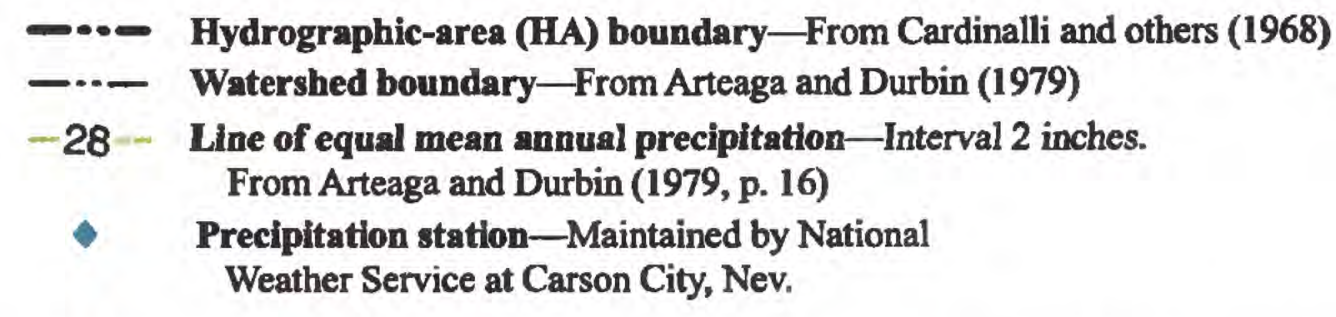

Figure 2. Mean annual precipitation, Eagle Valley Hydrographic Area, Nevada. 
falls during November through April. Snow in the Carson Range accumulates to several feet during most winters and melts in early spring to early summer.

The mean and median annual precipitation at the National Weather Service station in Carson City (fig. 2) are 10.87 and 10.22 in., respectively, for 1961-90 (Owenby and Ezell, 1992, p. 15). These values agree well with that estimated by Arteaga and Durbin (1979, p. 16). Therefore, the map developed by Arteaga and Durbin is used throughout this study for estimates of precipitation.

Using the map by Arteaga and Durbin (1979, p. 16), the total volume of precipitation within the Eagle Valley Hydrographic Area is about 67,000 acre$\mathrm{ft} / \mathrm{yr}$ (table 8 ). This volume is greater than a previous estimate for Eagle Valley of 58,000 acre-ft/yr (Worts and Malmberg, 1966, p. 15).

\section{Streams}

Streams in Ash and Kings Canyons and Clear Creek are perennial and flow onto the floor of Eagle Valley during most years. These streams drain the eastern flank of the Carson Range. The water is used in the valley for agricultural irrigation and municipal water supply. Other streams entering Eagle Valley are ephemeral, flowing onto the valley floor only during spring snowmelt or intense storms. Flow of Ash and Kings Canyon Creeks that remains after agricultural and municipal diversions, joins Eagle Valley creek (informal name), exits Eagle Valley north of Prison Hill, and discharges into the Carson River (fig. 1). Clear Creek flows eastward across the southernmost end of Eagle Valley, enters Carson Valley, and discharges into the Carson River.

\section{Geology}

The mountains surrounding Eagle Valley consist of consolidated rocks that have been uplifted by faulting. The valley floor has been downdropped relative to the mountains, forming a basin that is partly filled with sediments eroded from the surrounding mountains. In this report, the consolidated rocks exposed in the mountains and buried beneath the sediments in the valley are collectively called bedrock; the sediments in the valley are collectively called basin-fill sediments.

Granitic rocks of Cretaceous age and metamorphic rocks of Triassic age 60 to 200 million years old are exposed throughout the Carson Range and north of Eagle Valley on the southwestern flank of the Virginia Range (fig. 3). Granitic rocks have been variably weathered west of Eagle Valley; they are described as weathered to depths of more than $100 \mathrm{ft}$ near Clear Creek (Moore, 1969, p. 17), but were found to be unweathered $50 \mathrm{ft}$ below the buried bedrock contact near Vicee Canyon (Maurer and others, 1996, p. 19). Metamorphic rocks also are variable in their degree of fracturing and weathering. They were found to be highly fractured and permeable up to $70 \mathrm{ft}$ below the buried bedrock surface near Kings Canyon (Maurer and others, 1996, p. 19), but can have clay-filled fractures (Maurer and others, 1996, p. 20).

Volcanic rocks overlie granitic and metamorphic rocks in the eastern part of the Virginia Range (fig. 3). The volcanic rocks consist of rhyolites and andesites of Oligocene to Pliocene age 38 to 2 million years old, and basaltic rocks of Quaternary age as young as $1 \mathrm{mil}-$ lion years (Moore, 1969, p. 10-11; Bingler, 1977). For this report, the older volcanic rocks are grouped separately from the younger, basaltic rocks. The volcanic rocks consist of flows, flow breccias, and welded to non-welded tuffs. The flows and tuffs are described as scoriaceous and pumiceous (Bingler, 1977), thus having numerous vesicles or cavities formed by expansion of gases during solidification of the rocks. Bingler (1977) also describes bouldery cobble and gravel zones underlying many of the volcanic formations.

Basin-fill sediments that overlie bedrock are generally coarse grained near the base of the mountain blocks and finer grained near the center of the valley. These sediments form the principal ground-water reservoir for municipal supply. They are estimated to be about 1,200 ft thick $1.5 \mathrm{mi}$ west of Lone Mountain, about 400 to $800 \mathrm{ft}$ thick beneath the northeastern and southern parts of the valley, and about $2,000 \mathrm{ft}$ thick about $1 \mathrm{mi}$ northwest of Prison Hill (Arteaga, 1986, p. 25).

\section{Ground Water}

Ground water moving through bedrock and basin-fill sediments in Eagle Valley originates as precipitation that falls within the hydrographic area. In the mountains, part of the precipitation evaporates or is transpired by plants, part runs off as streamflow, and part infiltrates weathered or fractured bedrock. Water that infiltrates into bedrock moves toward the canyons and seeps into streams or moves down the canyon beneath the stream channels to Eagle Valley. Some ground water in fractured bedrock moves along deeper 

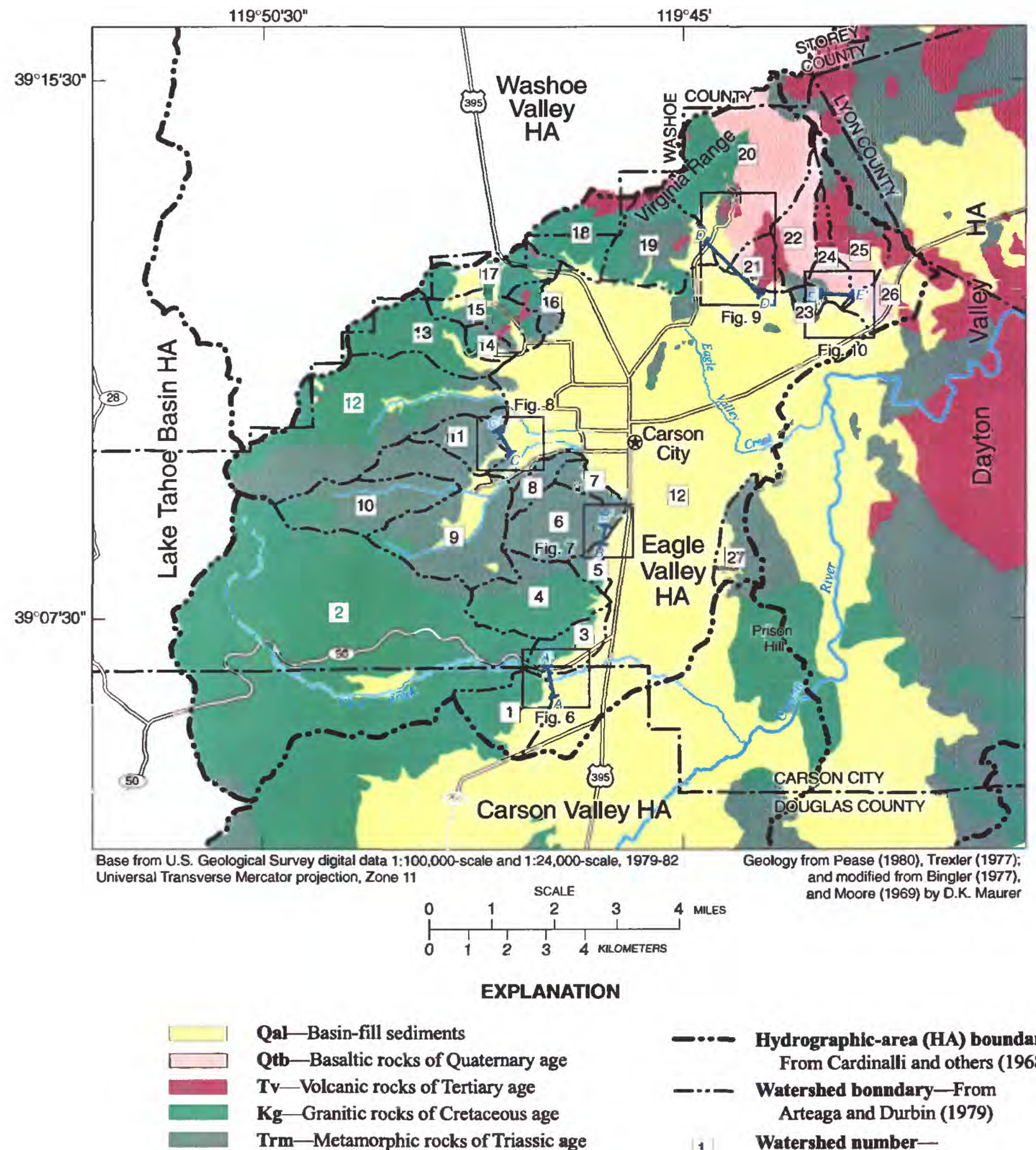

Qał-Basin-fill sediments

Qtb-Basaltic rocks of Quaternary age

Tv-Volcanic rocks of Tertiary age

$\mathrm{Kg}$ - Granitic rocks of Cretaceous age

Trm-Metamorphic rocks of Triassic age

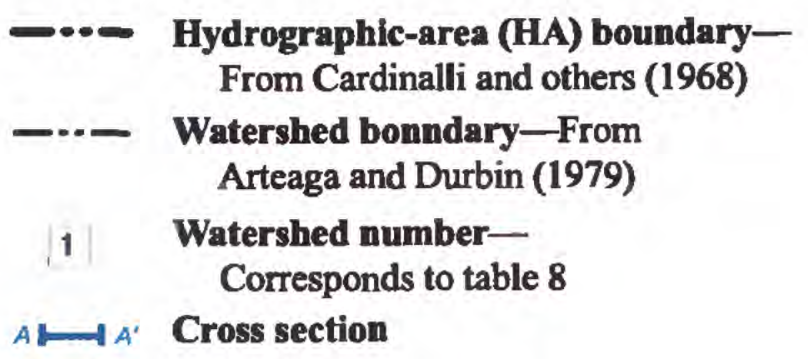

Area shown in indicated figure

Figure 3. Surficial geology of Eagle Valley Hydrographic Area, Nevada, and locations of cross sections and figures 6-10. 
flow paths into basin-fill sediments, and some discharges along fractures as thermal springs (Trexler and others, 1980, p. 23 and 81).

On the valley floor, part of the runoff from the mountains infiltrates into basin-fill sediments beneath the stream channels and irrigated lands, and the remainder flows out of the hydrographic area to discharge into the Carson River. The amount of recharge to basin-fill aquifers from precipitation on the valley floor is uncertain; Worts and Malmberg (1966, p. 15) estimated $400 \mathrm{acre}-\mathrm{ft} / \mathrm{yr}$, whereas Arteaga and Durbin $(1979$, p. 11) stated that recharge from precipitation was not significant. Basin-fill aquifers also could be recharged by lawn watering and the application of treated effluent for irrigation of fields and lawns.

Beneath the northern part of Eagle Valley, ground water flows eastward and discharges beneath the hydrographic area divide toward the Carson River and the Dayton Valley Hydrographic Area (fig. 1; Worts and Malmberg, 1966, p. 11; Arteaga, 1986, p. 6). Beneath the southern part of Eagle Valley, some ground water flows northeastward toward the northern end of Prison Hill, and some flows southeastward and discharges beneath the hydrographic-area divide into the Carson Valley Hydrographic Area (Worts and Malmberg, 1966, p. 11; Arteaga, 1986, p. 6).

Ground water in the basin fill aquifer is discharged also by pumping for municipal and domestic use, and by evapotranspiration, which includes evaporation from bare soil and transpiration by phreatophytes. In 1964, about 5,000 acres near the center of the valley were covered with phreatophytes and pasture grasses (Worts and Malmberg, 1966, p. 27). Since that time, many acres of phreatophytes and pasture grasses have been replaced by development. With increasing development, ground-water discharge by municipal pumping has increased and the area covered by phreatophytes has decreased.

\section{ESTIMATES OF SUBSURFACE FLOW FROM INSTRUMENTED WATERSHEDS}

Arteaga and Durbin (1979, p. 16) previously delineated 27 watersheds tributary to Eagle Valley; five of these were instrumented for this study, and three were instrumented for a previous study (Maurer and others, 1996). For purposes of this report, the instrumented watersheds (fig. 1) have been informally named: Clear Creek (watershed 2), C-Hill (watershed 6), southeastern Kings Canyon (watersheds 9 and 10), northwestern Kings Canyon (watershed 11), Ash
Canyon (watershed 12), Vicee Canyon (watersheds 13 and 14), Goni (watersheds 20 and 21), and Centennial Park (watershed 24).

\section{Methods Used}

Subsurface flow moving from the instrumented watersheds to basin-fill aquifers beneath Eagle Valley was estimated using two independent methodsapplication of Darcy's law and the chloride-balance method (Dettinger, 1989). Estimates from both methods are presented as a range of subsurface-flow volumes. The same methods were used previously to estimate subsurface flow from the watersheds of Vicee, Ash, and southeastern Kings Canyons (fig. 1), and these estimates are described by Maurer and others (1996).

Both methods use hydrologic data collected near the mouths of the instrumented watersheds. The watersheds were instrumented by installation of test holes and wells from which data were collected. Throughout this report, the term test hole is used to describe the borehole drilled at each site and the term well is used to describe the casing and screen installed in each test hole.

Test holes were drilled using the mud-rotary method and, for certain bedrock units, using an air-hammer and temporary ODEX casing. Prior to installation of well casing, test holes were logged with geophysical tools to obtain test-hole diameter and formation resistivity at $0.1-\mathrm{ft}$ intervals using a 16 -in. and 64-in. normal resistivity tool. From one to three wells of differing depths were installed in each test hole using 2 -in. casing and screens. The wells were developed with a combination of air-lifting, bailing, and surging and pumping.

Slug tests of the wells were made by lowering a cylinder below and then raising it above the static water level in the wells, to displace a known volume of water, and recording the change in water level over time. Slug test data were analyzed using the methods of Bouwer and Rice (1976) for most wells. The method of Kipp (1985) was used for the CC-1 shallow and Goni-1 wells (figs. 6 and 9), where water levels oscillated upon lowering and raising of the cylinder because of the high hydraulic conductivity of materials being tested.

Ground-water and surface-water samples were collected using methods described by Hardy and others (1989, p. 22-33) and Shelton (1994, p. 10). The samples were analyzed for major dissolved constituents, including chloride, by the U.S. Geological Survey 
National Water Quality Laboratory in Arvada, Colo. Specific conductance was measured in the U.S. Geological Survey Nevada District laboratory.

\section{Estimates Using Darcy's Law}

Subsurface flow was estimated with Darcy's law using measurements and estimates of physical properties of the aquifer materials beneath a cross section that is perpendicular to ground-water flow near the mouth of each watershed. The direction of subsurface flow and hydraulic gradient was estimated from available water-level data near each cross section. Darcy's law, as modified from Heath (1989, p. 12), can be expressed as:

$$
Q=0.0084 K A(d h / d l),
$$

where $Q$ is quantity of ground-water flow, in acre-feet per year;

$K$ is hydraulic conductivity, in feet per day; $A$ is the cross-sectional area through which flow occurs, perpendicular to the direction of flow, in square feet;

$(d h / d l)$ is the hydraulic gradient, in foot per foot; and 0.0084 is the factor to convert cubic feet per day into acre-feet per year.

Darcy's law was applied by totaling the flows through hydrogeologic units selected on the basis of hydraulic conductivity. Flows were totaled using the following equation:

$$
Q=\sum_{i=1}^{n} Q_{i},
$$

where $Q$ is total subsurface flow beneath the cross section, in acre-feet per year;

$Q_{i}$ is subsurface flow through selected hydrogeologic unit $i$, in acre-feet per year; and

$n$ is total number of hydrogeologic units.

Replacing $Q_{i}$ in equation 2 with the right side of equation 1 and assuming that the hydraulic gradient is the same for all hydrogeologic units produces:

$$
Q=0.0084 \sum_{i=1}^{n} K_{g} A_{i}(d h / d l),
$$

where $K_{g}$ is the geometric-mean hydraulic conductivity of each hydrogeologic unit, in feet per day; and

$A_{i}$ is the cross-sectional area of each hydrogeologic unit, in square feet.
The geometric-mean hydraulic conductivity $\left(K_{g}\right)$ for each unit was used because hydraulic conductivity generally has a log-normal distribution in sediments and rocks (Neuman, 1982, p. 83).

$K_{g}$ was calculated for the hydrogeologic units from the distribution of hydraulic conductivity within each unit. The distribution of hydraulic conductivity was determined from borehole resistivity data collected in each test hole. Several investigators (Alger, 1966; Croft, 1971; Kwader, 1985) have demonstrated a correlation between the two physical properties. Electrical resistivity measured in the test hole adjacent to gravel-packed intervals of wells was correlated by linear regression with hydraulic conductivity determined from slug tests of the same interval (fig. 4).

The correlation between electrical resistivity and hydraulic conductivity was determined separately for each instrumented watershed. Electrical resistivity was represented by a term called formation factor (Archie, 1942 , p. 55). Formation factor is the ratio of the average resistivity of the saturated sediments or rocks, in ohm-meters, as measured by the borehole tool, divided by the average resistivity, in ohm-meters, of the pore water measured from ground-water samples obtained from all wells in the watershed (table 1).

The equations and statistical results derived from the regression analyses are shown in table 2 . The coefficient of determination $\left(\mathrm{r}^{2}\right)$ indicates the percent of the total variation in hydraulic conductivity that is explained by the linear regression equation. For example, an $r^{2}$ of 0.83 indicates that 83 percent of the variation in the data is accounted for by the regression equation. In addition, the strength of the predictive relation between hydraulic conductivity and formation factor is indicated by a significance of probability value ( $p$-value). A small $p$-value indicates a stronger predictive relation between hydraulic conductivity and formation factor than a large $p$-value. Large $p$-values were obtained for regressions using only three data points (table 2), suggesting weak relations for these watersheds.

The equations in table 2 were then applied to the electrical resistivity data obtained at 0.1 -ft intervals for the saturated parts of the test holes to estimate the vertical distribution of hydraulic conductivity adjacent to the test hole (fig. 5). For most test holes, the 64-in. normal resistivity log was used. An exception was the 

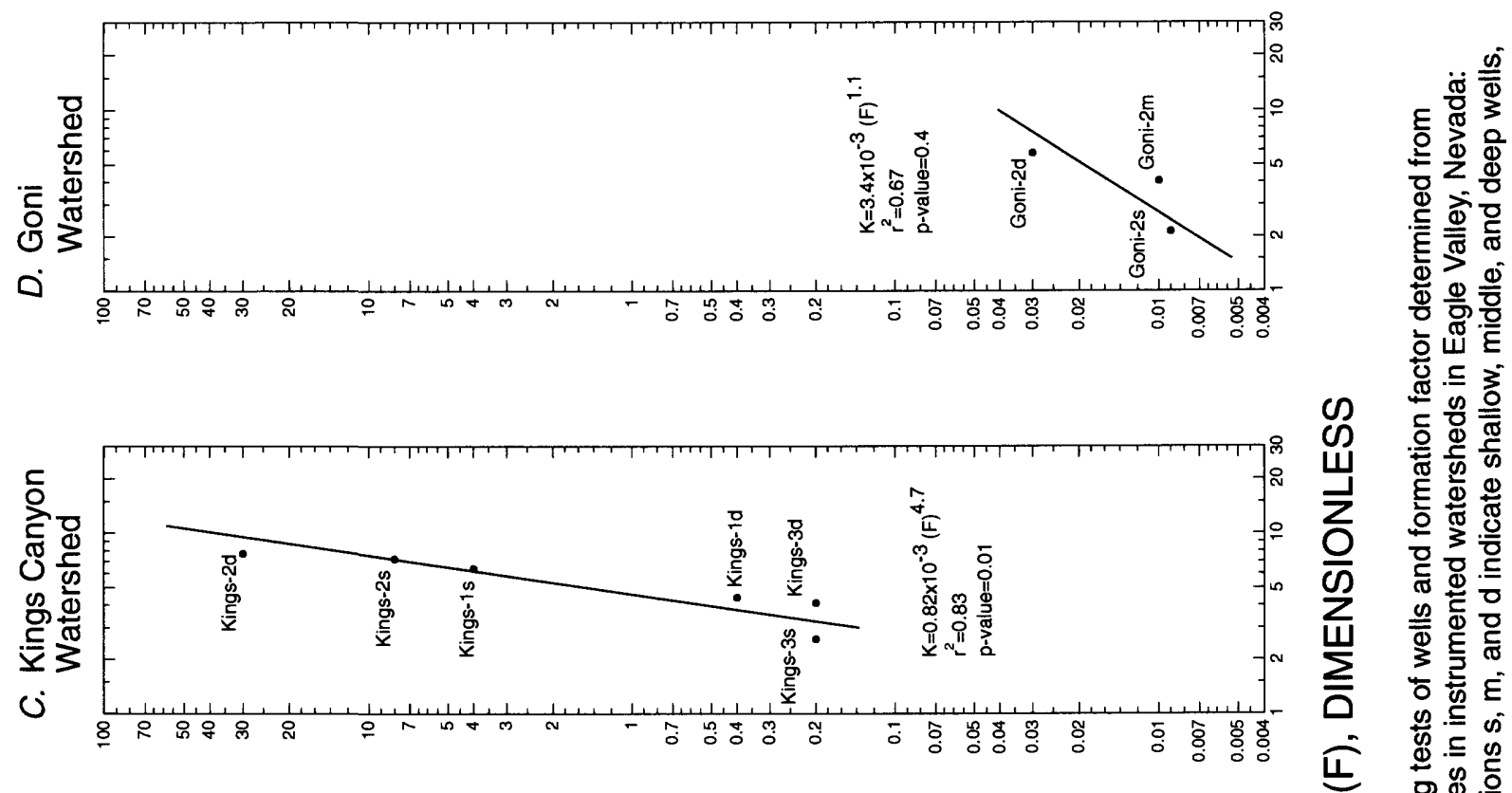

$\pm$

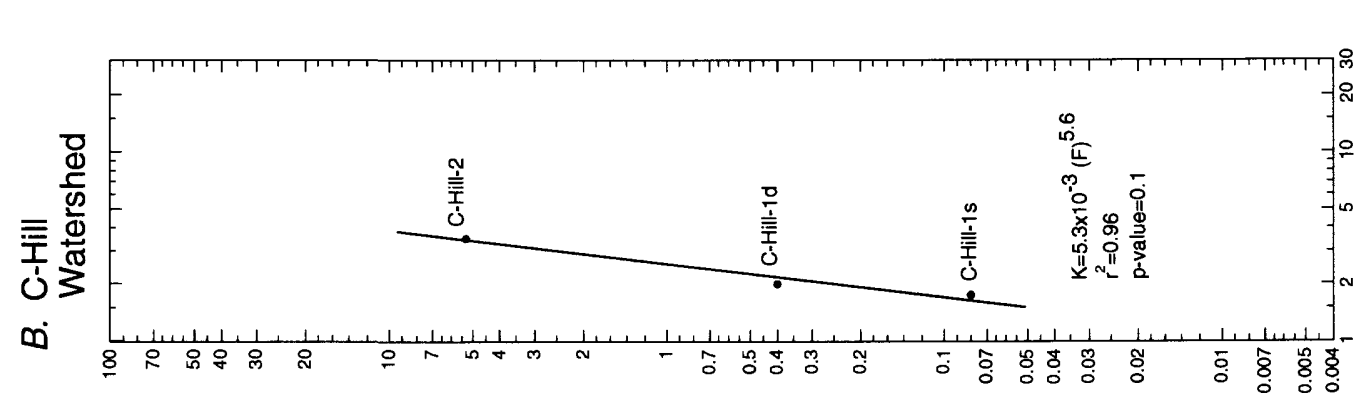

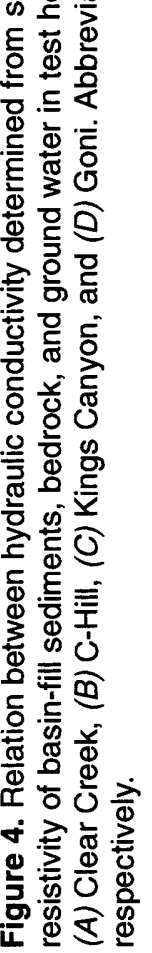

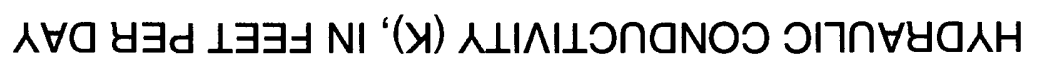


Table 1. Comparison of formation factor determined from resistivity of basin-fill sediments, bedrock, and ground water to average hydraulic conductivity determined from slug tests of selected wells in instrumented watersheds

[Abbreviation and symbol: CC, Clear Creek; $\mathrm{CH}, \mathrm{C}-\mathrm{Hill}$; CP, Centennial Peak; nd, not determined; $\mu \mathrm{S} / \mathrm{cm}$, microsiemens per centimeter at 25 degrees Celsius; --, no data available]

\begin{tabular}{|c|c|c|c|c|c|c|c|}
\hline Well & $\begin{array}{l}\text { Interval } \\
\text { used for } \\
\text { analysis }{ }^{1} \\
\text { (feet) }\end{array}$ & $\begin{array}{l}\text { Hydrogeologic unit } \\
\text { adjacent to interval }\end{array}$ & $\begin{array}{l}\text { Average } \\
\text { resistivity of } \\
\text { saturated } \\
\text { sediments or } \\
\text { bedrock }^{2} \\
\text { (ohm-meters) }\end{array}$ & $\begin{array}{c}\text { Specific } \\
\text { conductance } \\
(\mu \mathrm{S} / \mathrm{cm})\end{array}$ & $\begin{array}{c}\text { Average } \\
\text { equivalent } \\
\text { resistivity of } \\
\text { pore water }{ }^{3} \\
\text { (ohm-meters) }\end{array}$ & $\begin{array}{c}\text { Formation } \\
\text { factor }^{4}, F \\
\text { (dimension- } \\
\text { less) }\end{array}$ & $\begin{array}{c}\text { Average } \\
\text { hydraulic } \\
\text { conductivity }{ }^{5} \text {, } \\
\text { K } \\
\text { (feet per day) }\end{array}$ \\
\hline CC-1 shallow & $104-127$ & Basin-fill sediments & 250 & 163 & 69.8 & 3.58 & 30 \\
\hline CC-1 deep & $287-311$ & Granitic rocks & 251 & 150 & 69.8 & 3.60 & 5 \\
\hline CC-2 shallow & $131-167$ & Basin-fill sediments & 250 & 227 & 69.8 & 3.58 & 6 \\
\hline CC-2 middle & $208-236$ & Granitic rocks & 154 & 225 & 69.8 & 2.21 & .4 \\
\hline CC-2 deep & $375-400$ & Granitic rocks & 194 & 157 & 69.8 & 2.78 & 1 \\
\hline $\mathrm{CH}-1$ shallow & $125-155$ & Basin-fill sediments & 76 & 342 & 43.6 & 1.74 & .08 \\
\hline CH-1 deep & $215-241$ & Metamorphic rocks & 87 & 228 & 43.6 & 2.00 & .4 \\
\hline $\mathrm{CH}-2$ & $129-149$ & Metamorphic rocks & 152 & 266 & 43.6 & 3.49 & 5 \\
\hline Kings- 1 shallow & $86-108$ & Basin-fill sediments & 315 & 274 & 49.3 & 6.39 & 4 \\
\hline Kings-1 deep & $170-190$ & Metamorphic rocks & 219 & 231 & 49.3 & 4.44 & .4 \\
\hline Kings- 2 shallow & $82-104$ & Basin-fill sediments & 356 & 258 & 49.3 & 7.22 & 8 \\
\hline Kings-2 deep & $155-174$ & Metamorphic rocks & 380 & 241 & 49.3 & 7.71 & 30 \\
\hline Kings- 3 shallow & $61-85$ & Metamorphic rocks & 128 & 332 & 49.3 & 2.60 & .2 \\
\hline Kings-3 deep & $175-201$ & Metamorphic rocks & 203 & 326 & 49.3 & 4.12 & .2 \\
\hline Goni-1 & $166-170$ & Cobble zone in basalt & nd & 355 & nd & -- & $300-500$ \\
\hline Goni-2 shallow & $109-131$ & Basin-fill sediments & 55 & 597 & 25.8 & 2.13 & .009 \\
\hline Goni- 2 middle & $150-167$ & Metamorphic rocks & 105 & 403 & 25.8 & 4.07 & .01 \\
\hline Goni-2 deep & $219-238$ & Metamorphic rocks & 150 & 381 & 25.8 & 5.81 & .03 \\
\hline Goni-3 & $105-139$ & Basin-fill sediments & 74 & 368 & nd & -- & 30 \\
\hline CP-1 & $99-126$ & Basaltic rocks & 122 & 206 & nd & -- & 3 \\
\hline \multicolumn{8}{|c|}{$\begin{array}{l}{ }^{1} \text { Thickness of gravel placed near well screen for gravel-packed interval, except for Goni-l, which is screened interval. } \\
2 \text { Average (true) resistivity determined from normal resistivity log and corrected for mud invasion and hole diameter. } \\
{ }^{3} \text { Average equivalent resistivity of ground water determined from specific conductance measurement and corrected to formation temperature. } \\
{ }^{4} \text { Ratio of resistivity of saturated sediments or bedrock divided by resistivity of pore water. } \\
{ }^{5} \text { Average hydraulic conductivity from method of Bouwer and Rice (1976). Average hydraulic conductivity from method of Kipp (1985) for Goni-1 and } \\
\text { shallow. }\end{array}$} \\
\hline
\end{tabular}

$\mathrm{CH}-1$ test hole, where the 64-in. normal resistivity log appeared to be malfunctioning so the 16-in. normal log was used.

Hydrogeologic units were selected from the distribution using arbitrary limits of hydraulic conductivity. For basin-fill sediments, hydraulic conductivity values less than $0.1 \mathrm{ft} / \mathrm{d}$ were assumed to represent silt and clay to sandy clay, values between 0.1 and $1 \mathrm{ft} / \mathrm{d}$ represented clayey to silty sand, values between 1 and
$10 \mathrm{ft} / \mathrm{d}$ represented fine sand, and values greater than 10 $\mathrm{ft} / \mathrm{d}$ represented coarse sand and gravel. For bedrock, hydraulic conductivity values less than $0.1 \mathrm{ft} / \mathrm{d}$ were assumed to represent unweathered bedrock, bedrock with closed fractures, or bedrock completely weathered to clay; values between 0.1 and $1.0 \mathrm{ft} / \mathrm{d}$ represented partly weathered bedrock or bedrock with sedimentfilled fractures; and values greater than $1 \mathrm{ft} / \mathrm{d}$ represented highly weathered bedrock or bedrock with open fractures. 
Table 2. Equations and statistical results derived from linear regression analysis used to describe relation between hydraulic conductivity and formation factor in selected instrumented watersheds of Eagle Valley

\begin{tabular}{llcc}
\hline Watershed & \multicolumn{1}{c}{ Equation ${ }^{1}$} & $\begin{array}{c}\text { Coefficient } \\
\text { of deter- } \\
\text { mination }^{2} \\
{\left(\mathbf{r}^{2}\right)}^{2}\end{array}$ & $\begin{array}{c}\text { Significance } \\
\text { of prob- }^{2}\end{array}$ \\
$\begin{array}{llcc}\text { ability }^{3} \\
(\boldsymbol{p} \text {-value })\end{array}$ \\
\hline Clear Creek & $\mathrm{K}=1.4 \times 10^{-3}(\mathrm{~F})^{6.9}$ & 0.80 & 0.04 \\
C-Hill & $\mathrm{K}=5.3 \times 10^{-3}(\mathrm{~F})^{5.6}$ & .96 & .1 \\
Kings Canyon & $\mathrm{K}=0.82 \times 10^{-3}(\mathrm{~F})^{4.7}$ & .83 & .01 \\
Goni & $\mathrm{K}=3.4 \times 10^{-3}(\mathrm{~F})^{1.1}$ & .67 & .4 \\
\hline
\end{tabular}

${ }^{1}$ Equations derived from linear regression analysis where $\mathrm{K}$ is hydraulic conductivity, in feet per day, and $\mathrm{F}$ is formation factor, dimensionless.

${ }^{2}$ Coefficient of determination $\left(\mathrm{r}^{2}\right)$ indicates the percent of variation in the data accounted for by the regression equation.

${ }^{3}$ Significance of probability indicates the strength of the predictive relation between hydraulic conductivity and formation factor. A small $p$ value indicates a stronger predictive relation than a large $p$-value.

The geometric-mean hydraulic conductivity for each hydrogeologic unit was computed from:

$$
K_{g}=10^{x},
$$

where

$$
x=\frac{\sum_{i=1}^{n} \log _{10}\left(K_{i}\right)}{n},
$$

and $K_{g}$ is geometric-mean hydraulic conductivity, in feet per day;

$K_{i}$ is hydraulic conductivity of the $i^{\text {th }}$ interval in the hydrogeologic unit, in feet per day; and

$n$ is the total number of $0.1-\mathrm{ft}$ intervals in the hydrogeologic unit.

Equations 4 and 5 were used in a Fortran program (David E. Prudic, U.S. Geological Survey, written commun., 1996) to calculate the geometric-mean hydraulic conductivity and thickness of each hydrogeologic unit in basin-fill sediments and bedrock for the test holes (tables 3 and 4).

To estimate the cross-sectional area, $A_{i}$, of each hydrogeologic unit, the thickness of each unit calculated for the test holes was assumed to be representative of the entire cross section and could be extrapolated across the section. The cross-sectional area of each hydrogeologic unit was estimated using the equation:

$$
A_{i}=A_{T}\left(b_{i} / b_{T}\right)
$$

where $A_{T}$ is the total area of basin-fill sediments or bedrock determined from a scaled cross section, in square feet;

$b_{i}$ is the thickness of each hydrogeologic unit penetrated by test holes near the section, in feet; and

$b_{T}$ is the total thickness of basin-fill sediments or bedrock penetrated by test holes near the section, in feet.

Assuming that the hydraulic gradient measured near the cross section is the same for all hydrogeologic units, equation 3 was solved using the geometric-mean hydraulic conductivity and cross-sectional area of each hydrogeologic unit (table 5).

\section{Estimates Using Chloride-Balance Method}

The chloride-balance method assumes that (1) all chloride dissolved in surface and ground water is derived from precipitation and dry fallout within the watershed, and (2) a balance exists between chloride deposited from the atmosphere and chloride that leaves the watershed, either as surface runoff or as subsurface flow. Subsurface flow from the watershed can be estimated, as modified from Dettinger $(1989$, p. 59$)$, by:

$$
Q_{s}=\left(Q_{p}\left(C_{p}\right) / C_{s}\right)-\left(Q_{r}\left(C_{r}\right) / C_{s}\right),
$$

where $Q_{s}$ is subsurface flow, in acre-feet per year;

$C_{s}$ is average dissolved-chloride concentration in ground water, in milligrams per liter;

$Q_{p}$ is average volume of precipitation, in acrefeet per year;

$C_{p}$ is average dissolved-chloride concentration of precipitation, in milligrams per liter;

$Q_{r}$ is average surface runoff, in acre-feet per year; and

$C_{r}$ is average dissolved-chloride concentration of surface runoff, in milligrams per liter.

The average volume of precipitation within each watershed was determined from a map developed by Arteaga and Durbin (1979, p. 16) for the Eagle Valley Hydrographic Area. Precipitation on the parts of watersheds 1 and 3 upgradient from the cross section near the mouth of Clear Creek was included in the estimate 
A. CC-1 test hole

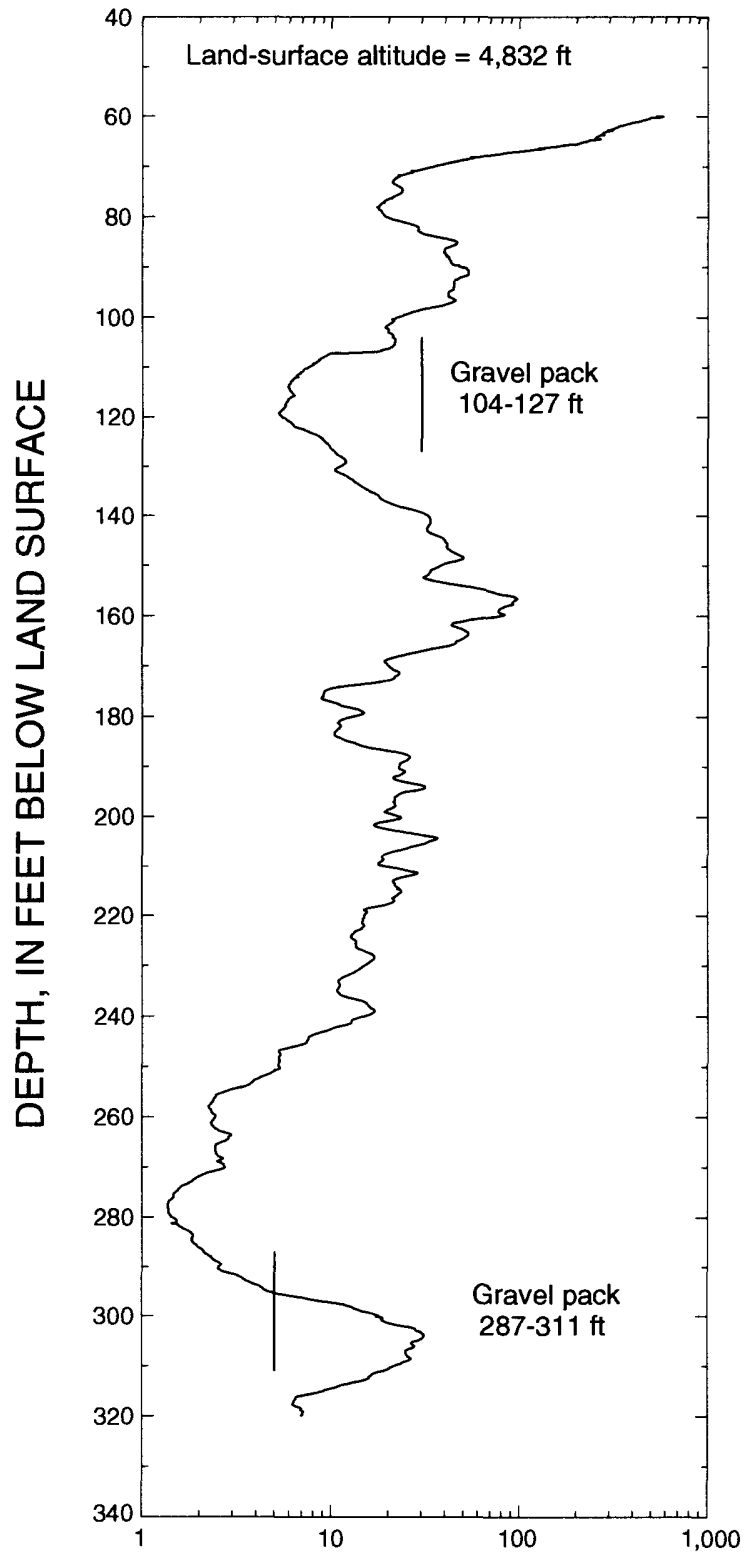

B. CC-2 test hole

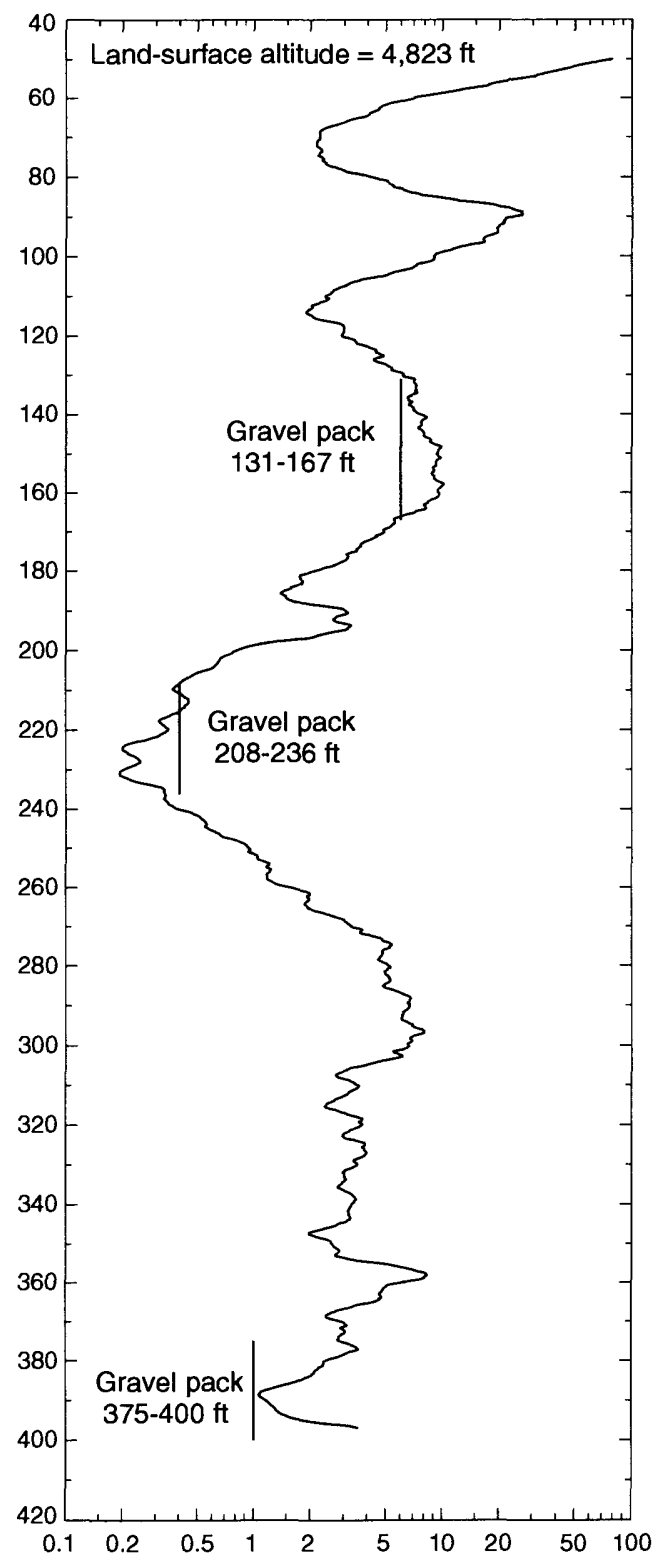

HYDRAULIC CONDUCTIVITY, IN FEET PER DAY

Figure 5. Distribution of hydraulic conductivity calculated from normal resistivity logs for test holes in Clear Creek $(A, B)$, C-Hill $(C, D)$, Kings Canyon $(E)$, and Goni $(F)$ watersheds, Eagle Valley, Nevada. All were calculated from 64 -in. normal resistivity logs except $\mathrm{CH}-1$, which was from 16 -in. log. Vertical bars represent hydraulic conductivity determined from slug test of wells screened in test hole.

Location of test holes is shown in figures 6-10. 
C. $\mathrm{CH}-1$ test hole

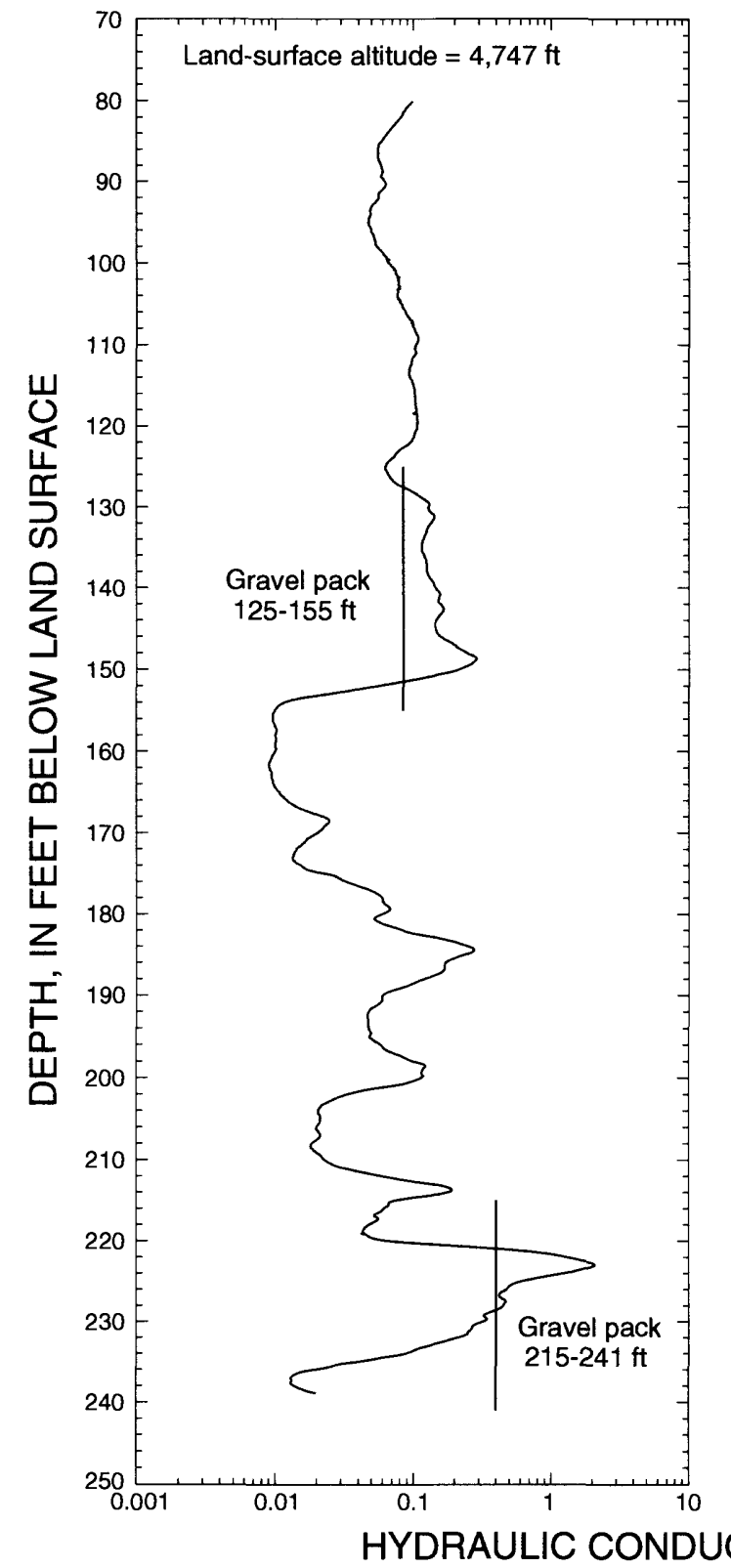

D. $\mathrm{CH}-2$ test hole

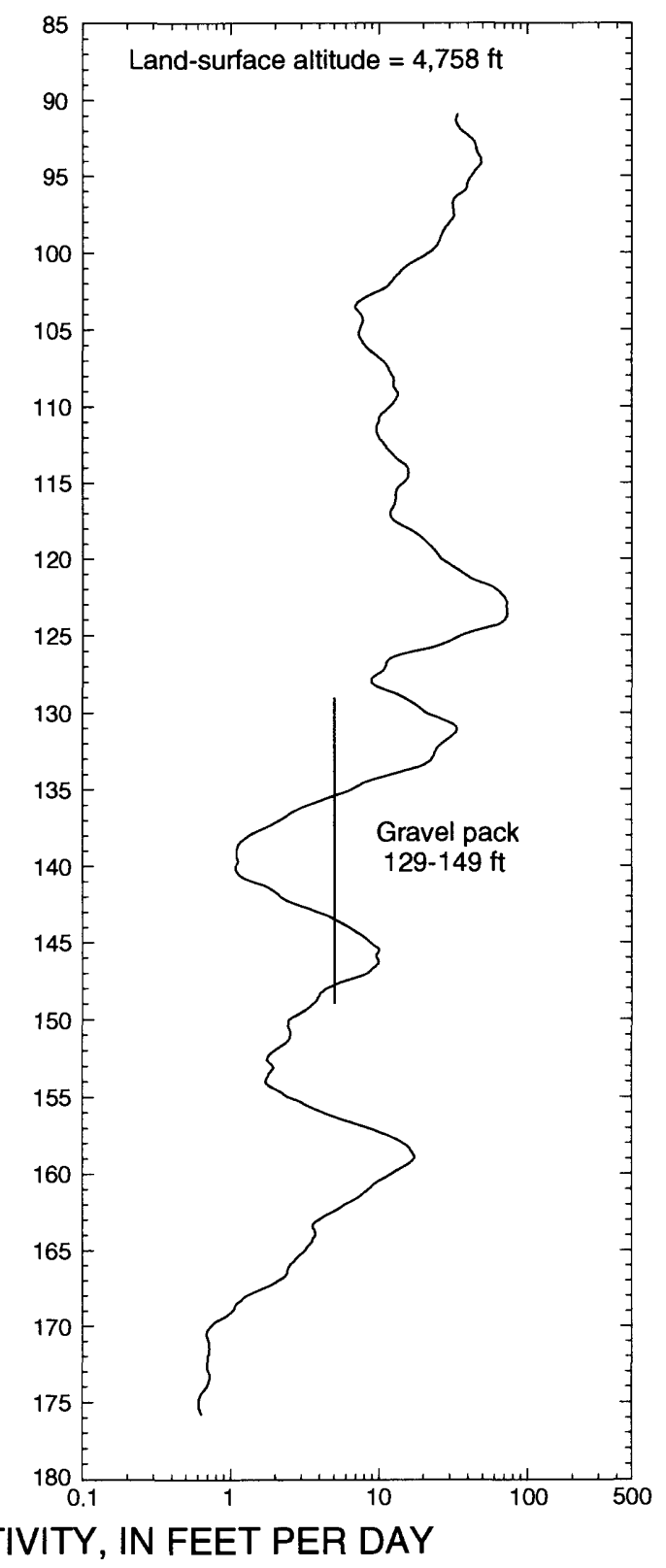

Figure 5. Continued. 
E. Kings-3 test hole

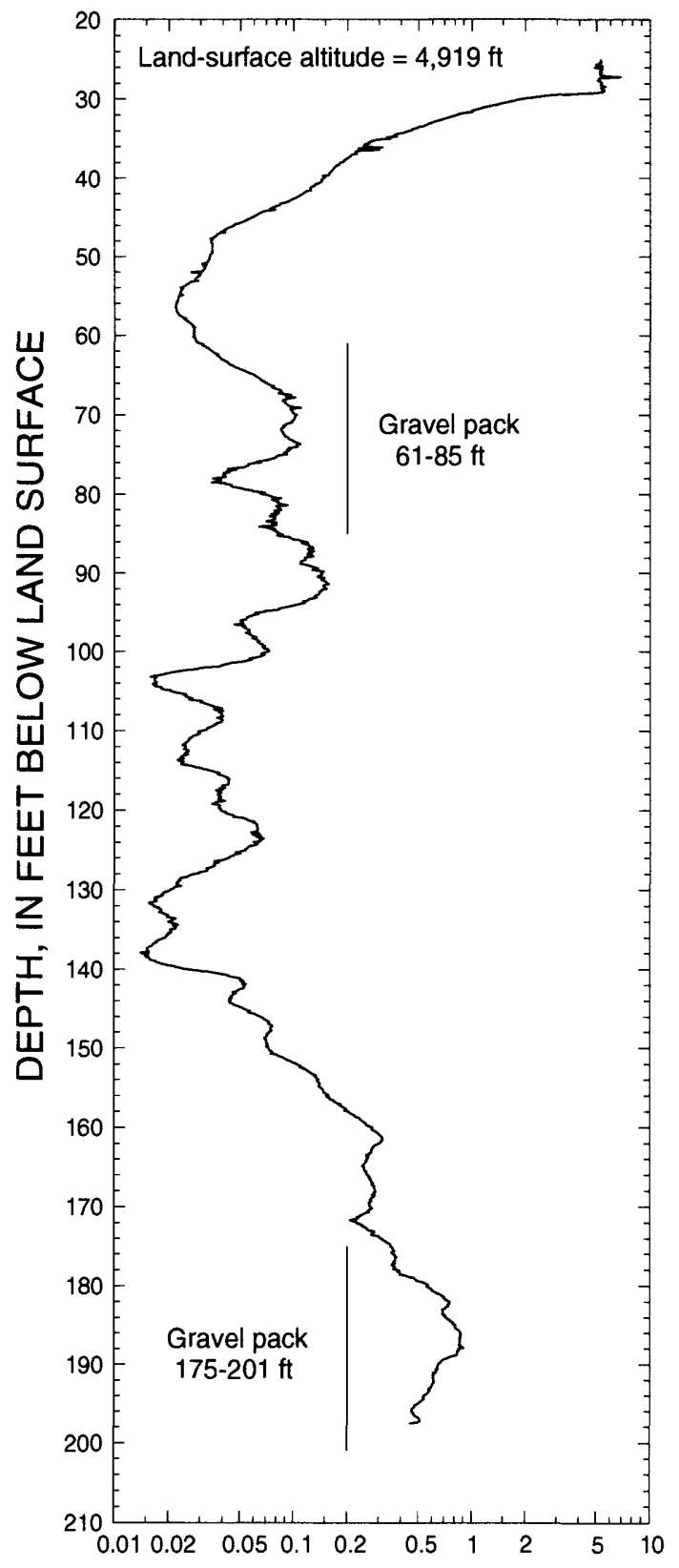

F. Goni-2 test hole

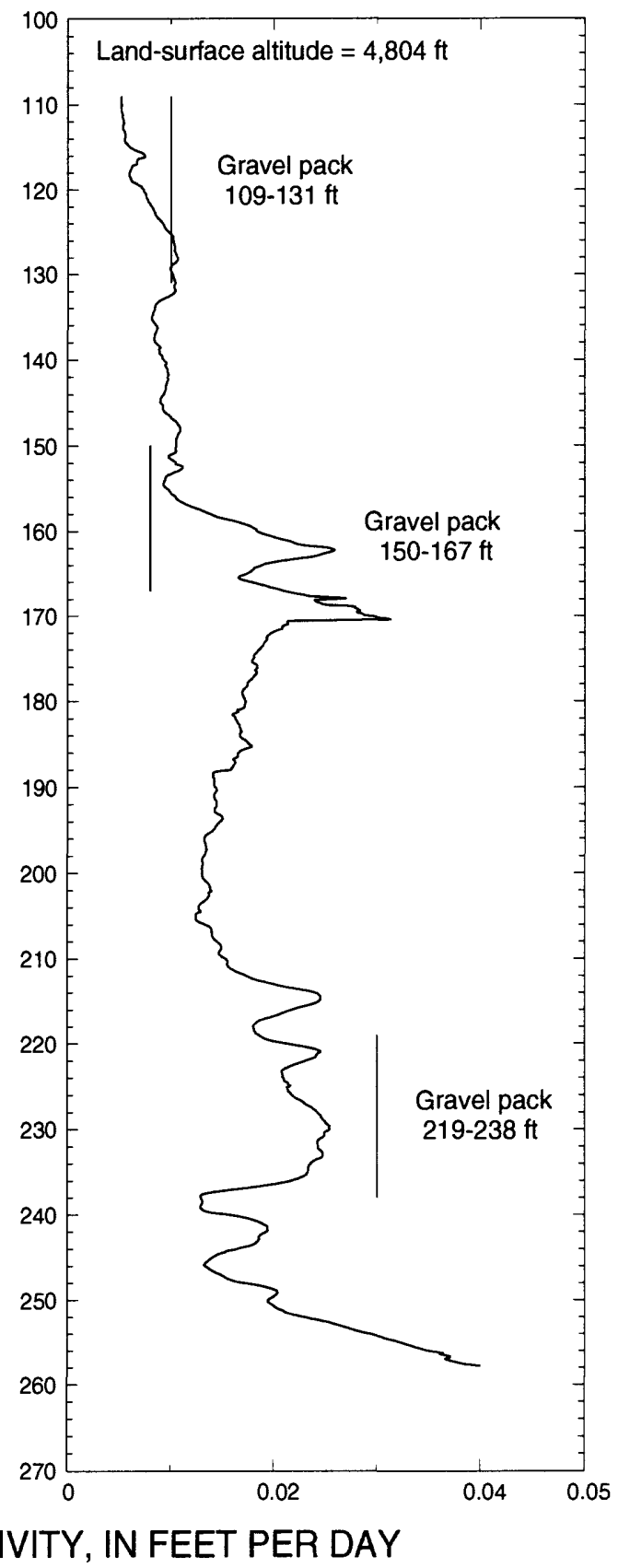

Figure 5. Continued. 


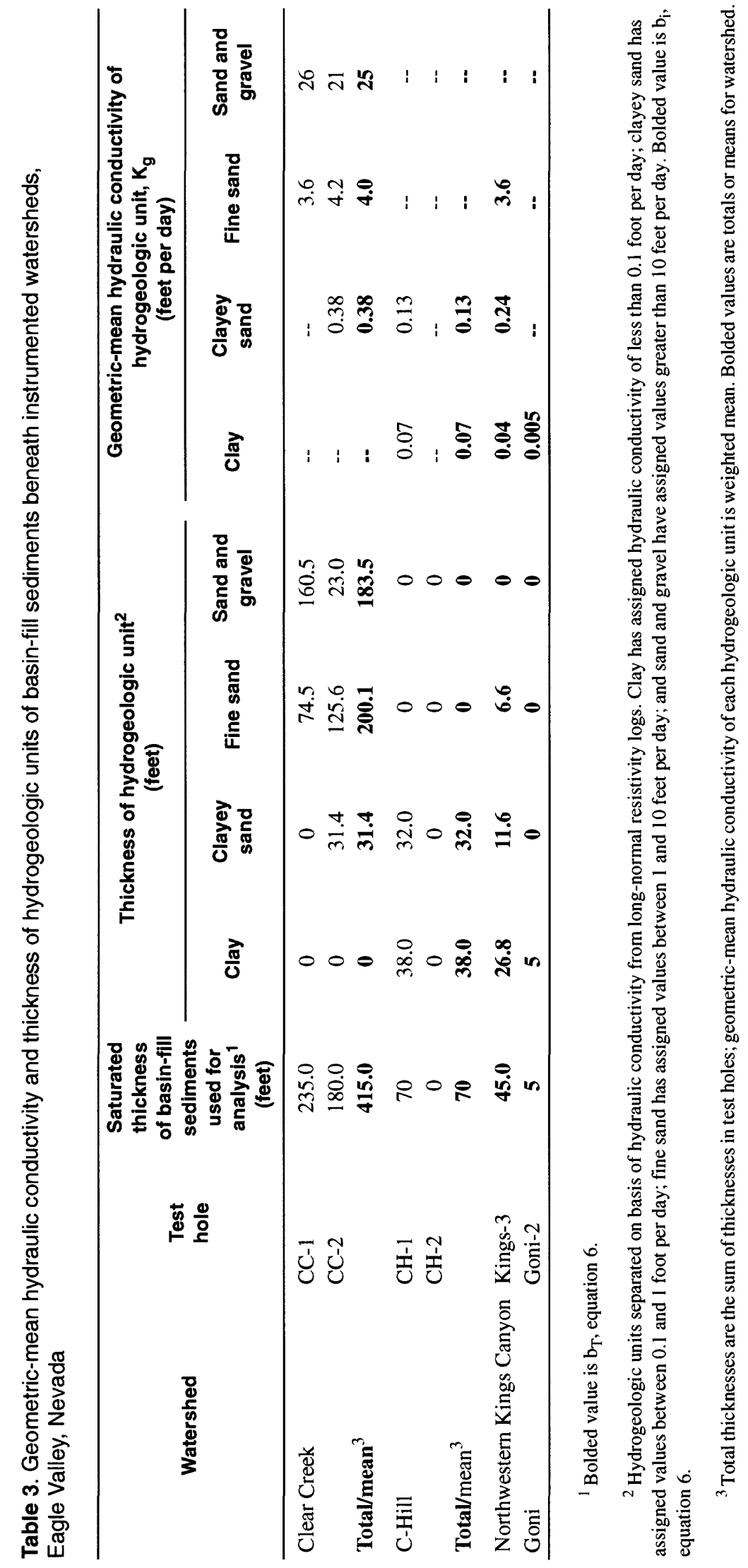




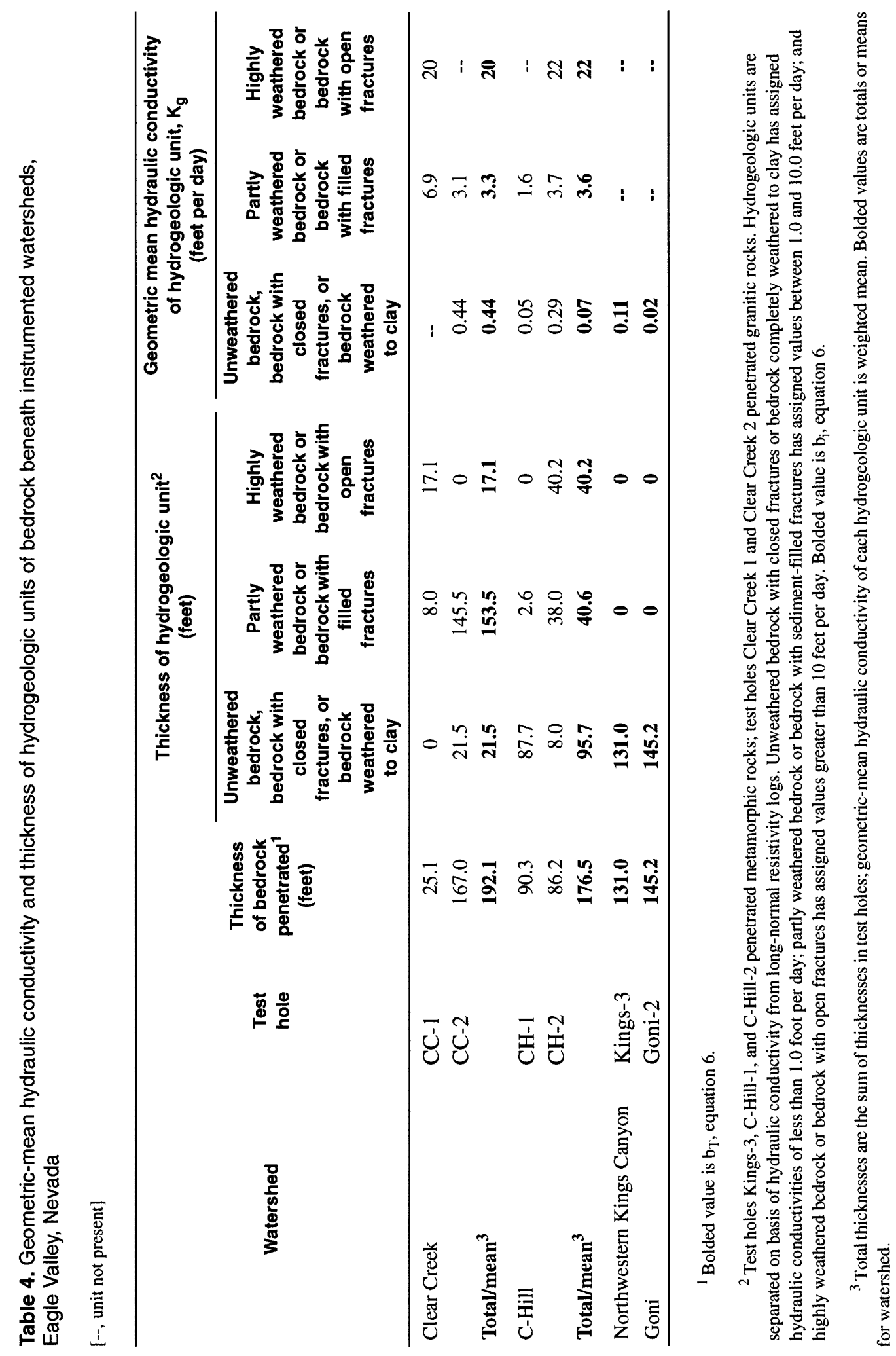


Table 5. Estimates of subsurface flow beneath instrumented watersheds, Eagle Valley, Nevada, using Darcy's law at cross sections across each watershed

\begin{tabular}{|c|c|c|c|c|c|}
\hline $\begin{array}{l}\text { Watershed name, number } \\
\text { (cross section) }\end{array}$ & Hydrogeologic unit & $\begin{array}{c}\text { Saturated } \\
\text { area of } \\
\text { hydrogeologic } \\
\text { unit, } A_{i}, \text { and } \\
\text { section } 1, A_{T} \\
\text { (square feet) }\end{array}$ & $\begin{array}{l}\text { Water-table } \\
\text { gradient, dh/dl } \\
\text { (foot per foot) }\end{array}$ & $\begin{array}{l}\text { Geometric-mean } \\
\text { hydraulic } \\
\text { conductivity }{ }^{2}, K_{\mathrm{g}} \\
\text { (feet per day) }\end{array}$ & $\begin{array}{c}\text { Estimated } \\
\text { subsurface } \\
\text { flow }^{3}, Q \\
\text { (acre-feet } \\
\text { per year) }\end{array}$ \\
\hline \multirow{8}{*}{$\begin{array}{r}\text { Clear Creek, } 2 \\
\left(A-A^{\prime}, \text { fig. } 6\right)\end{array}$} & Sand and gravel & 247,500 & 0.015 & 25 & 780 \\
\hline & Fine sand & 269,900 & .015 & 4.0 & 136 \\
\hline & Clayey sand & 42,600 & .015 & .38 & 2 \\
\hline & Basin-fill sediments & 560,000 & & & 920 \\
\hline & $\begin{array}{l}\text { Highly weathered bed- } \\
\text { rock or bedrock with } \\
\text { open fractures }\end{array}$ & 41,000 & .015 & 20 & 103 \\
\hline & $\begin{array}{l}\text { Weathered bedrock or } \\
\text { bedrock with sedi- } \\
\text { ment-filled fractures }\end{array}$ & 367,500 & .015 & 3.3 & 152 \\
\hline & $\begin{array}{l}\text { Unweathered bedrock, } \\
\text { bedrock with closed } \\
\text { fractures, or bedrock } \\
\text { completely weathered } \\
\text { to clay }\end{array}$ & 51,500 & .015 & .44 & 3 \\
\hline & Bedrock & 460,000 & & & 260 \\
\hline Total flow (rounded) & & & & & 1,200 \\
\hline \multirow{7}{*}{$\begin{array}{l}\text { C-Hill, } 6 \\
\quad\left(B-B^{\prime}, \text { fig. } 7\right)\end{array}$} & Clayey sand & 8,200 & .004 & .13 & .04 \\
\hline & Clay & 9,800 & .004 & .07 & .02 \\
\hline & Basin-fill sediments & 18,000 & & & .06 \\
\hline & $\begin{array}{l}\text { Highly weathered bed- } \\
\text { rock or bedrock with } \\
\text { open fractures }\end{array}$ & 27,100 & .004 & 22 & 20 \\
\hline & $\begin{array}{l}\text { Weathered bedrock or } \\
\text { bedrock with sedi- } \\
\text { ment-filled fractures }\end{array}$ & 27,400 & .004 & 3.6 & 3.3 \\
\hline & $\begin{array}{l}\text { Unweathered bedrock, } \\
\text { bedrock with closed } \\
\text { fractures, or bedrock } \\
\text { completely weathered } \\
\text { to clay }\end{array}$ & 64,500 & .004 & .07 & .15 \\
\hline & Bedrock & 119,000 & & & 20 \\
\hline Total flow (rounded) & & & & & 20 \\
\hline \multirow{5}{*}{$\begin{array}{l}\text { Northwestern Kings Canyon, } 11 \\
\quad\left(C^{-} C^{\prime} \text {, fig. } 8\right)\end{array}$} & Fine sand & 8,600 & 0.05 & 3.6 & 13 \\
\hline & Clayey sand & 15,200 & .05 & .24 & 1.5 \\
\hline & Clay & 35,200 & .05 & .04 & .6 \\
\hline & Basin-fill sediments & 59,000 & & & 15 \\
\hline & $\begin{array}{r}\text { Bedrock completely } \\
\text { weathered to clay }\end{array}$ & 222,000 & .05 & .11 & 10 \\
\hline Total flow (rounded) & & & & & 20 \\
\hline
\end{tabular}


Table 5. Estimates of subsurface flow beneath instrumented watersheds, Eagle Valley, Nevada, using Darcy's law at cross sections across each watershed-Continued

\begin{tabular}{|c|c|c|c|c|c|}
\hline $\begin{array}{l}\text { Watershed name, number } \\
\text { (cross section) }\end{array}$ & Hydrogeologic unit & $\begin{array}{c}\text { Saturated } \\
\text { area of } \\
\text { hydrogeologic } \\
\text { unit, } A_{i,} \text {, and } \\
\text { section } 1, A_{T} \\
\text { (square feet) }\end{array}$ & $\begin{array}{l}\text { Water-table } \\
\text { gradient, dh/dl } \\
\text { (foot per foot) }\end{array}$ & $\begin{array}{l}\text { Geometric-mean } \\
\text { hydraulic } \\
\text { conductivity }{ }^{2}, \mathrm{~K}_{\mathrm{g}} \\
\text { (feet per day) }\end{array}$ & $\begin{array}{c}\text { Estimated } \\
\text { subsurface } \\
\text { flow }^{3}, Q \\
\text { (acre-feet } \\
\text { per year) }\end{array}$ \\
\hline Goni, 20 and 21 & Basin-fill sediments & $\mathbf{0}$ & & & 0 \\
\hline \multirow[t]{4}{*}{ (D-D', fig. 9) } & Cobble zone & 27,000 & .014 & 439 & 124 \\
\hline & Basaltic rock & 294,000 & .014 & 49 & 311 \\
\hline & $\begin{array}{l}\text { Bedrock completely } \\
\text { weathered to clay }\end{array}$ & 780,000 & .014 & .02 & 1 \\
\hline & Bedrock & $1,101,000$ & & & 400 \\
\hline Total flow (rounded) & & & & & 400 \\
\hline \multirow{4}{*}{$\begin{array}{l}\text { Centennial Park, } 24 \\
\quad\left(E-E^{\prime} \text {, fig. } 10\right)\end{array}$} & Basin-fill sediments & $\mathbf{0}$ & & & 0 \\
\hline & Basaltic rock & 108,000 & .011 & $5_{3}$ & 30 \\
\hline & Metamorphic rock & 86,000 & .011 & ${ }^{6}$ low & 0 \\
\hline & Bedrock & 194,000 & & & 30 \\
\hline Total flow (rounded) & & & & & 30 \\
\hline
\end{tabular}

\footnotetext{
${ }^{1}$ Non-bolded values are areas of hydrogeologic units, bolded values are total areas of geologic sections. Saturated area for each hydrogeologic unit estimated by multiplying the total area of either basin-fill sediments or bedrock with the ratio of (a) the thickness of each hydrogeologic unit (tables 3 and 4 ) penetrated by test holes in each canyon to (b) total thickness of basin-fill sediments or bedrock penetrated by test holes (equation 6 in text)

${ }^{2}$ Geometric mean hydraulic conductivity from tables 3 and 4 .

${ }^{3}$ Subsurface flow for each hydrogeologic unit computed by multiplying values in columns $3-5$ and result by 0.0084 (equation 3 , in text). Total flow in each canyon is sum of flows computed for each hydrogeologic unit and rounded to nearest 100 acre-feet per year.

${ }^{4}$ Equivalent hydraulic conductivity determined from equation 8, in text. Equal to distance between Goni-1 and Goni-3 divided by (distance from Goni1 to edge of basalt or cobble zone divided by hydraulic conductivity of basalt or cobble zone) plus (distance from edge of basalt or cobble zone to Goni-3 divided by hydraulic conductivity of basin-fill sediments).

${ }^{5}$ Hydraulic conductivity determined from slug tests.

${ }^{6}$ Hydrogeologic unit not tested, hydraulic conductivity assumed to be low.
}

of precipitation within watershed 2 . The average dissolved-chloride concentration of precipitation was assumed to be $0.4 \mathrm{mg} / \mathrm{L}$ on the basis of samples collected throughout Nevada and in Eagle Valley (Dettinger, 1989, p. 63; Berger and others, 1997, p. 46).

Average surface runoff was measured at Clear Creek (table 8) and was estimated for the other instrumented watersheds using the method developed by Moore (1968, p. 33), and described in detail in this report (see section titled "Estimates of Water Yield"). As part of the second phase of study, the dissolvedchloride concentration of runoff was measured at Clear, Kings Canyon, North Fork Kings Canyon, and Ash Canyon Creeks during the 1996 water year.

Concentrations of dissolved chloride sampled in the streamflow of Clear Creek varied considerably, ranging from $37 \mathrm{mg} / \mathrm{L}$ in February 1996 to $7 \mathrm{mg} / \mathrm{L}$ in September 1996 (James L. Wood, U.S. Geological Survey, written commun., 1996). This variation is probably caused by runoff from U.S. Highway 50 , where salt is applied during winter months. In comparison, dissolved-chloride concentrations in streamflow of Kings Canyon, North Fork Kings Canyon, and Ash Canyon Creeks ranged from $1.7 \mathrm{mg} / \mathrm{L}$ in February 1996 to $0.2 \mathrm{mg} / \mathrm{L}$ in September 1996. Weighted mean dissolved-chloride concentrations calculated for Kings Canyon, North Fork Kings Canyon, and Ash Canyon Creeks from February through September 1996 were $1.1,0.3$, and $0.3 \mathrm{mg} / \mathrm{L}$, respectively. Runoff from Kings Canyon also could be affected by salt applied to roads upstream from the sampling point, whereas no roads are upstream from the sampling points for the other streams. Thus, the dissolved-chloride concentration of runoff was assumed to be similar to that of precipitation $(0.4 \mathrm{mg} / \mathrm{L}$, table 6$)$. The dissolved-chloride concentration of ground water beneath the cross sections was obtained from samples collected in September 1996. 
Table 6. Estimates of subsurface flow beneath instrumented watersheds, Eagle Valley, Nevada, using chloride-balance method

[Abbreviation: acre-ft/yr, acre-feet per year. Subsurface flow rounded to two significant figures; chloride concentrations rounded to nearest 0.1 milligram per liter]

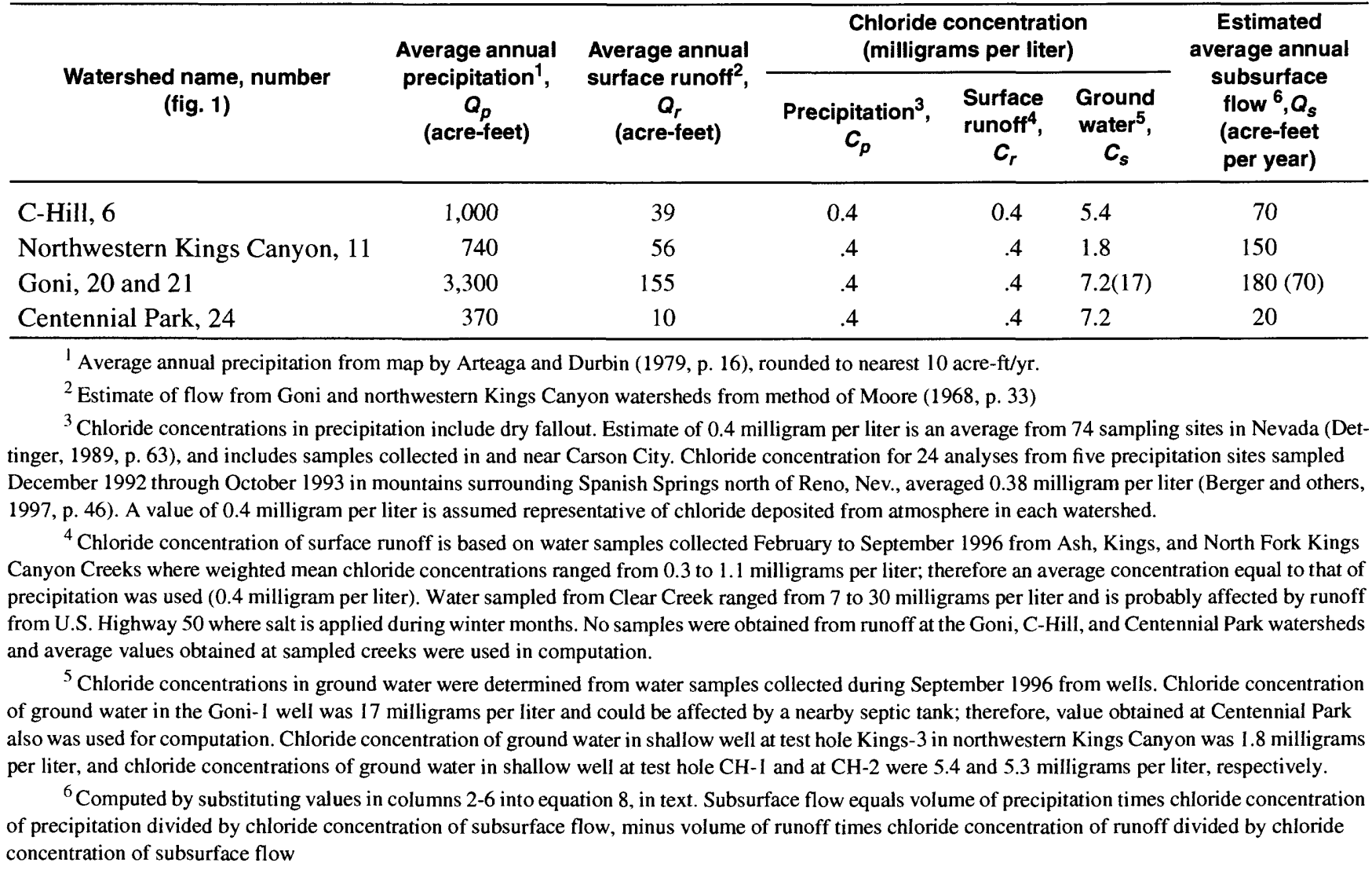

\section{Accuracy of Estimates}

The accuracy of the subsurface-flow estimates is limited by assumptions used to make the estimates. For the estimates made using Darcy's law, the geometry of basin-fill sediments and bedrock beneath the cross section is extrapolated between the control points of geologic contacts mapped on the surface and contacts penetrated by test holes. The geometry of basin-fill sediments and bedrock beneath the cross section remains uncertain in some watersheds. The accuracy of the estimated subsurface flow is directly proportional to the accuracy of the estimated area and hydraulic conductivity of the hydrogeologic units. The accuracy of the estimates of area and hydraulic conductivity are limited by the assumptions that borehole resistivity provides a reasonable estimate of the vertical distribution of hydraulic conductivity for each test hole, and that the distribution determined for the test holes can be extrapolated across the entire cross section. Statistical $p$-values show a weak correlation between borehole resistivity and hydraulic conductivity for the C-Hill and Goni watersheds.

Maurer and others (1996, p. 13) found that the hydraulic gradient can increase across the basin-fill/ bedrock contact, and that the hydraulic gradient and flow direction calculated using wells screened in bedrock can be inaccurate because the water table between the wells might not be a flat surface. In some watersheds, wells screened in bedrock are the only wells available for determination of hydraulic gradient.

Test holes drilled for the study do not always extend to solid, impermeable bedrock, and crosssectional areas for bedrock are estimated from the maximum depth of test holes. If ground water does flow beneath the cross sections at depths greater than the test holes, estimates of subsurface flow are minimum values. 
For estimates made using the chloride-balance method, dissolved-chloride concentrations used for precipitation, ground water, and surface runoff are assumed to represent average values, and chloride is assumed to not enter the system from sources other than precipitation and dry fallout. The dissolvedchloride concentration of ground water was determined from one sample, and surface runoff has been sampled for less than 1 year. The dissolved-chloride concentration of precipitation was shown by Berger and others (1997, p. 46) to vary seasonally and with location in a basin near Reno, Nev. Continued sampling of dissolved-chloride concentration of precipitation, ground water, and surface runoff would provide data from which long-term average values could be calculated. Weathering of bedrock, infiltration of effluent from septic tanks, or salting of roads could contribute chloride to ground water upgradient from the wells used for sampling. If chloride from any of these sources is entering the watershed, the estimates of subsurface flow represent minimum values.

\section{Clear Creek Watershed}

The Clear Creek watershed (2) is underlain mostly by granitic rocks, with some small exposures of metamorphic rock (fig. 3). Because the mouth of the watershed is in a narrow canyon, the cross section was selected downslope from the watershed where access for installation of wells was possible (fig. $6 A$ ). Subsurface flow beneath the section probably includes flow generated in parts of watersheds 1 and 3 (fig. 1) upgradient from the section. Granitic rocks are exposed at the northwestern end of the cross section and were penetrated by CC-1 and CC-2 (fig. 6B) at depths of approximately 290 and $230 \mathrm{ft}$, respectively (fig. $6 A$ and $B$ ). The depth to bedrock is approximate because the granitic rocks are extremely weathered and friable, and difficult to distinguish from the granitic sands and gravels in the basin-fill sediments. Cores taken from the bottom of each hole showed considerable variability in weathering. Sections of the cores 2-3 in. long crumbled upon removal from the core barrel, some sections remained intact but were friable, and some sections were weathered to clay along fracture planes. The depth to bedrock beneath the southeastern end of the section is not known, and is assumed to be about the same depth as in test hole CC-1. Wells CC-3 and CC-4 (fig. $6 \mathrm{~A}$ ) are shallow wells installed by hand auger to obtain a hydraulic gradient.
The water-table gradient calculated from water levels at shallow wells CC- $1, \mathrm{CC}-2$, and CC- 3 was $0.015 \mathrm{ft} / \mathrm{ft}$ in a direction about $80^{\circ}$ from true north (fig. 6A). Using shallow wells CC-1, CC-2, and CC-4, a gradient of $0.014 \mathrm{ft} / \mathrm{ft}$ was determined in the same direction.

The vertical gradient calculated between the shallow and deep wells at CC- 1 was $0.007 \mathrm{ft} / \mathrm{ft}$ in a downward direction. The water level in the deep well was about $1.3 \mathrm{ft}$ lower than in the shallow well: greater than would be expected from the horizontal gradient $(0.04$ $\mathrm{ft}$ ), assuming that subsurface flow is parallel to the water table (downslope flow), the horizontal gradient is uniform with depth, and the test hole is vertical (for additional information, see Maurer and others, 1996, p. 15). This implies a potential for downward flow and a thickening of basin-fill sediments to the east. The vertical gradient between the shallow and middle well at CC-2 was $0.005 \mathrm{ft} / \mathrm{ft}$, also downward, with a water-level difference of $0.4 \mathrm{ft}$. The vertical gradients between the shallow and deep, and middle and deep wells were 0.0006 and $0.003 \mathrm{ft} / \mathrm{ft}$, respectively, in an upward direction. Overlying clayey sand may partly confine ground water in the granitic rocks, or the small head difference may only show an upward hydraulic gradient.

From the scaled cross section (fig. $6 A$ ), the area of saturated basin-fill sediments beneath section $A-A^{\prime}$ is about $560,000 \mathrm{ft}^{2}$ (table 5). Assuming that the granitic rocks are permeable to ground-water flow through the same thickness as that penetrated by CC-2 $(170 \mathrm{ft})$, the cross-sectional area of granitic rocks is about $460,000 \mathrm{ft}^{2}$.

The hydraulic conductivity of basin-fill sediments near Clear Creek is large; $6 \mathrm{ft} / \mathrm{d}$ was calculated for the shallow well at CC-2, and $30 \mathrm{ft} / \mathrm{d}$ was calculated for the shallow well at CC-1 (table 1). The weathered granitic rocks also have a fairly large hydraulic conductivity near the deep well at CC-1 (5 ft/d). Granitic rocks with clay-filled fractures near the middle and deep wells at CC-2 have hydraulic conductivities of $0.4 \mathrm{ft} / \mathrm{d}$ and $1 \mathrm{ft} / \mathrm{d}$, respectively.

Geometric-mean hydraulic conductivities calculated for hydrogeologic units in basin-fill sediments at Clear Creek ranged from $0.38 \mathrm{ft} / \mathrm{d}$ for clayey sand to 25 $\mathrm{ft} / \mathrm{d}$ for sand and gravel (table 3). A similar range was obtained for hydrogeologic units in bedrock-about $0.44 \mathrm{ft} / \mathrm{d}$ for unweathered bedrock with a thickness of about $20 \mathrm{ft}$ and from 3.3 to $20 \mathrm{ft} / \mathrm{d}$ for most of the bedrock penetrated by the test holes (table 4 ). 


\section{EXPLANATION}

For geologic map and hydrogeologic section:

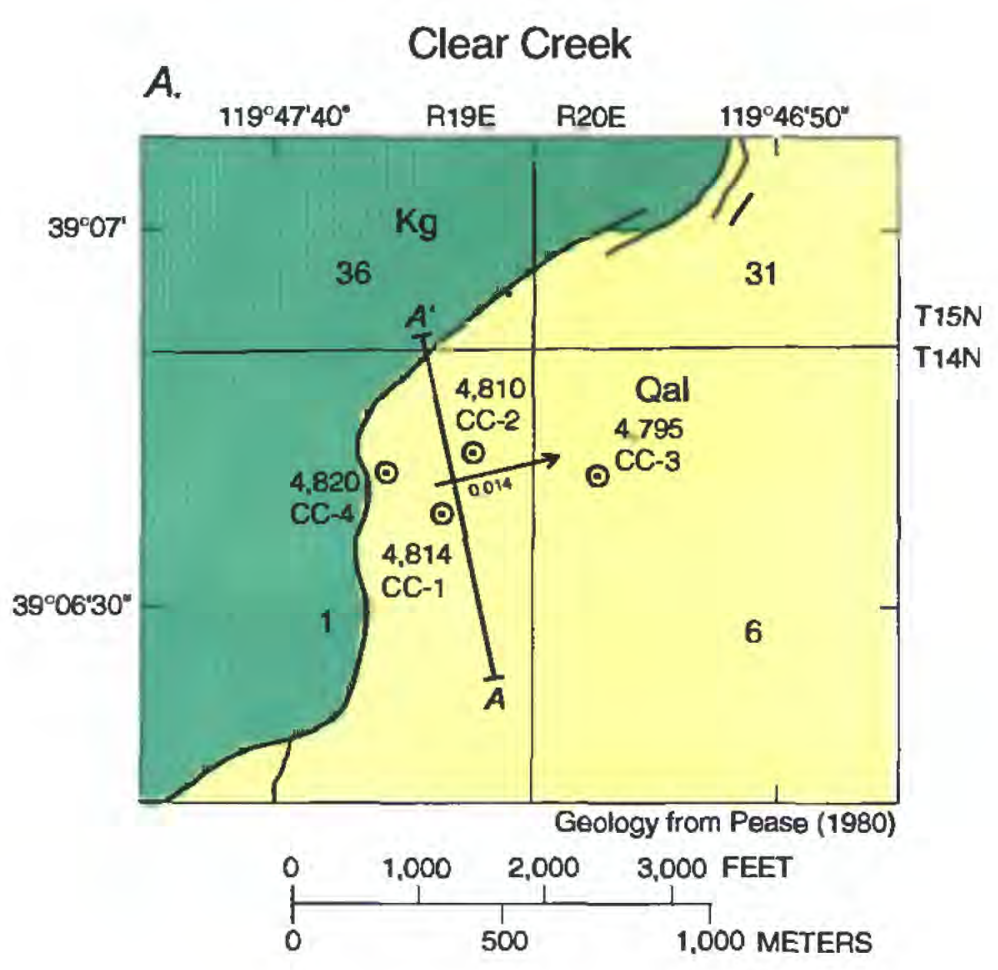

Qal-Basin-fill sediments

ran

Qal Basin-fill sediments

$\mathrm{Kg}-$ Granitic rocks of Cretaceous age

For geologic map:

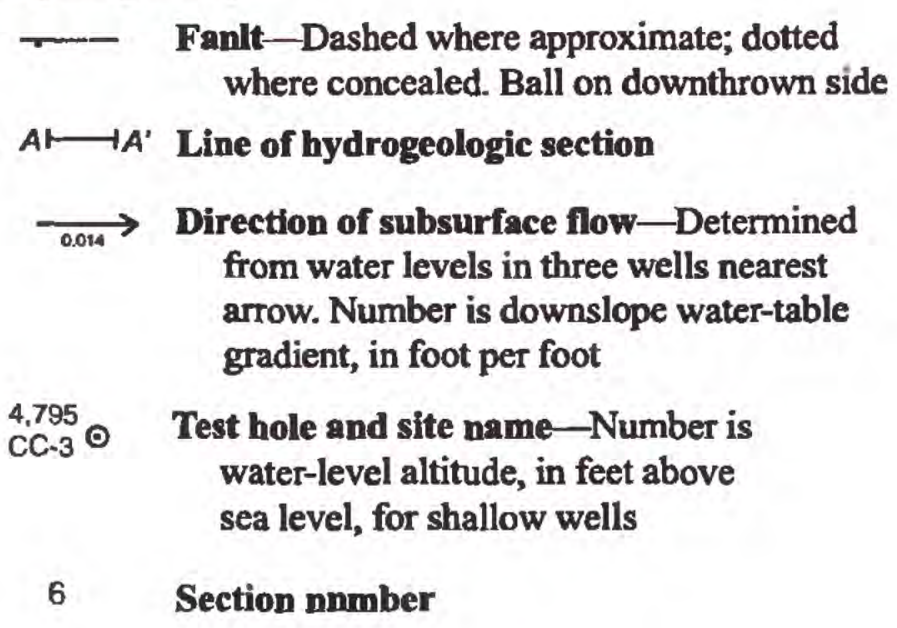

For hydrogeologic section:
-?.-- - Water table - Queried where uncertain
$\rightarrow--$ Base of weathered and fractured zone in bedrock - Approximately located; queried where uncertain
Fault-Arrows show relative vertical movement. Depth of fault is uncertain

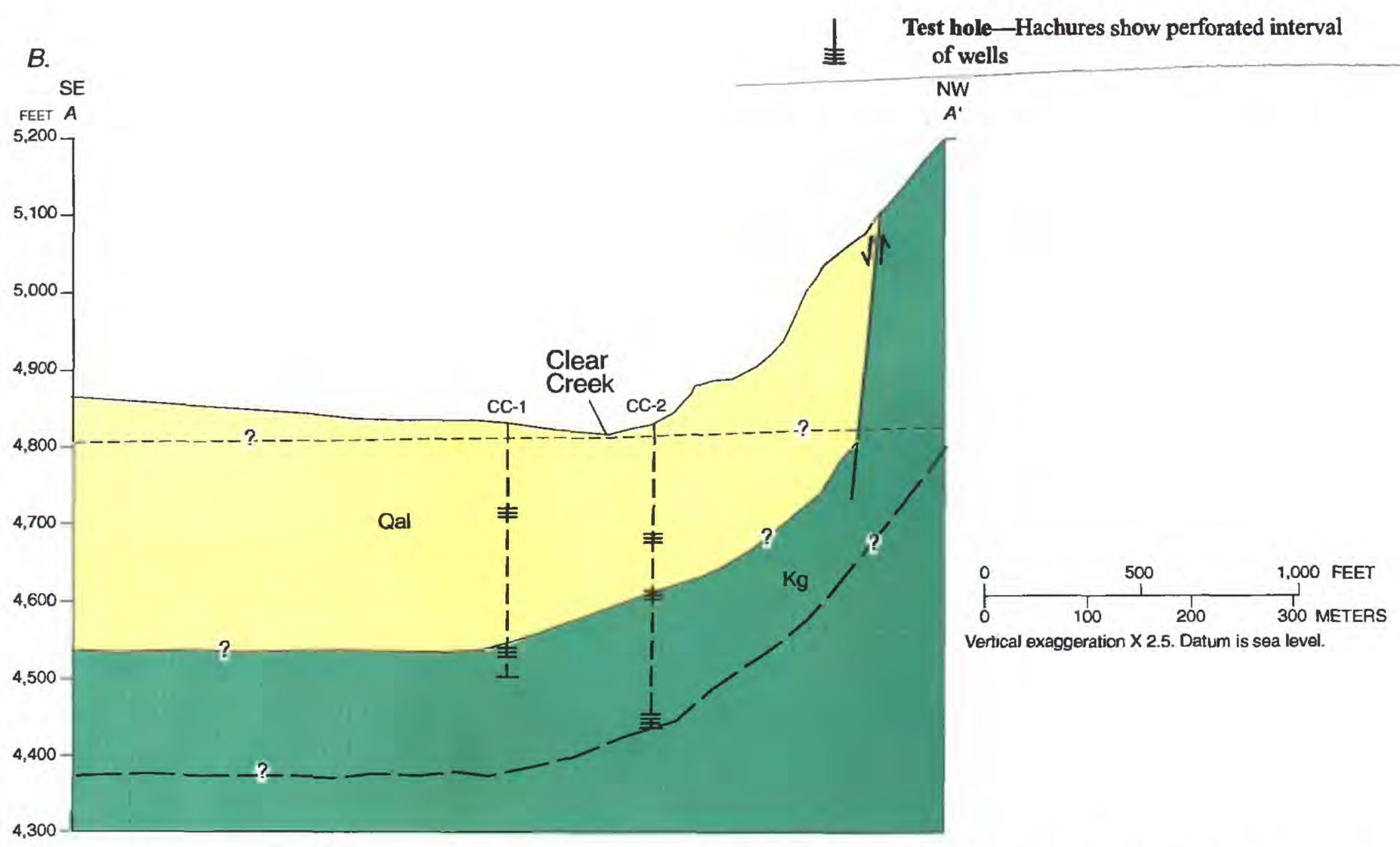

Figure 6. Surficial geology, location of wells and cross section, and direction of subsurface flow and downslope watertable gradient $(A)$, and cross section showing distribution of saturated and unsaturated basin-fill sediments and bedrock $(B)$ for Clear Creek watershed, Eagle Valley, Nevada. Location shown on figure 3. 
Subsurface flow through basin-fill sediments was estimated to be about 920 acre- $\mathrm{ft} / \mathrm{yr}$ and through bedrock about 260 acre-ft/yr, for a total estimate of 1,200 acre-ft/yr (table 5). Because permeable granitic bedrock could extend to depths greater than that penetrated by test hole CC-2, the estimate of subsurface flow through bedrock may be a minimum value. In addition, if granitic bedrock beneath the southern watershed boundary west of watershed 1 is permeable (fig. 3), ground water could flow beneath the boundary toward Carson Valley. Additional wells along the hydrographic-area boundary in this area would confirm this possibility.

Annual precipitation within the watershed is 23,000 acre-ft and surface runoff is 4,000 acre- $\mathrm{ft}$ (table 8 ). However, because an unknown amount of chloride is added to the watershed by road salt applied to U.S. Highway 50 during the winter, the chloride-balance method was not used to estimate subsurface flow from this watershed. As described earlier, concentrations of dissolved chloride sampled in the streamflow varied from 7 to $37 \mathrm{mg} / \mathrm{L}$ (James L. Wood, U.S. Geological Survey, written commun., 1996). Ground-water sampled near Clear Creek was variable also in dissolved chloride $-4.2 \mathrm{mg} / \mathrm{L}$ in the deep well at CC-2, $3.1 \mathrm{mg} / \mathrm{L}$ in the shallow and middle wells at CC-2, and $1.5 \mathrm{mg} / \mathrm{L}$ in the shallow well at CC-1 (Carl E. Thodal, U.S. Geological Survey, written commun., 1996). Test hole CC2 is close to U.S. Highway 50 and infiltration of runoff from the highway may cause the concentrations of chloride in ground water to be higher than in CC-1. Dissolved-chloride concentrations for streamflow or ground water not influenced by runoff from the highway cannot be determined with any degree of certainty.

\section{C-Hill Watershed}

The C-Hill watershed (6) is underlain by metamorphic rocks (fig. 3). They are exposed on both ends of the cross section and were penetrated at depths of $150 \mathrm{ft}$ and $46 \mathrm{ft}$ in test holes $\mathrm{CH}-1$ and $\mathrm{CH}-2$, respectively (fig. $7 A$ and $B$ ). About $60 \mathrm{ft}$ of saturated basin-fill sediments overlie the metamorphic rocks at $\mathrm{CH}-1$, and basin-fill sediments are unsaturated at $\mathrm{CH}-2$. Metamorphic rocks in both test holes had zones of clay-filled fractures, 5-20 ft thick, alternating with zones with little clay, 3-14 ft thick. The lower $70 \mathrm{ft}$ of basin-fill sediments overlying the metamorphic rocks at $\mathrm{CH}-1$ were mostly clay. The Borst well (fig. $7 A$ ) is an unused domestic well of unknown depth and lithology.
The water-table gradient calculated from water levels at the shallow CH-1, CH-2, and Borst wells (appendix 2) is $0.004 \mathrm{ft} / \mathrm{ft}$ in a direction about $100^{\circ}$ from true north (fig. 7A). The vertical gradient calculated from water levels in the shallow and deep wells at $\mathrm{CH}-1$ was $0.155 \mathrm{ft} / \mathrm{ft}$ in an upward direction. The water level in the deep well was about $13.7 \mathrm{ft}$ higher than in the shallow well. The estimated hydraulic conductivity for metamorphic rocks overlying the gravel-packed interval of the deep well at CH-1 (fig. 5C) is as low as $0.01 \mathrm{ft} / \mathrm{d}$, possibly confining ground water in the deep well.

From the scaled cross section (fig. 7A), the area of saturated basin-fill sediments beneath the section $B-B^{\prime}$ is $18,000 \mathrm{ft}^{2}$ (table 5). The metamorphic rocks were assumed to be permeable to ground-water flow through the same thickness as penetrated by $\mathrm{CH}-2$ (about $130 \mathrm{ft}$; fig. 7B). The cross-sectional area of metamorphic rocks is about $119,000 \mathrm{ft}^{2}$ (table 5).

The slug tests in the shallow and deep wells at $\mathrm{CH}-1$ resulted in hydraulic conductivities of 0.08 and $0.4 \mathrm{ft} / \mathrm{d}$ for basin-fill sediments and metamorphic rocks, respectively (table 1 ). The hydraulic conductivity obtained for metamorphic rocks at $\mathrm{CH}-2$, however, was $5 \mathrm{ft} / \mathrm{d}$, indicating that the hydraulic conductivity of the metamorphic rocks can be highly variable.

The geometric-mean hydraulic conductivity estimated for basin-fill sediments ranged from 0.07 to 0.13 $\mathrm{ft} / \mathrm{d}$ (table 3 ). The range was much greater for the metamorphic bedrock, ranging from 0.07 to $22 \mathrm{ft} / \mathrm{d}$ for a thickness of about $40 \mathrm{ft}$ (table 4). Subsurface flow estimated using Darcy's law was about 20 acre-ft/yr (table 5) with only a minor amount moving through basin-fill sediments.

Annual precipitation within the watershed is about 1,000 acre- $\mathrm{ft}$ and average annual surface runoff from the watershed is estimated to be $39 \mathrm{acre}-\mathrm{ft} / \mathrm{yr}$. Using dissolved-chloride concentrations of $5.4 \mathrm{mg} / \mathrm{L}$ for ground water and $0.4 \mathrm{mg} / \mathrm{L}$ for surface runoff, subsurface flow from the watershed is estimated to be about 70 acre-ft/yr (table 6).

\section{Northwestern Kings Canyon Watershed}

The northwestern Kings Canyon watershed (11) is underlain by metamorphic rocks (fig. 3). They are exposed at both ends of the cross section and about 130 $\mathrm{ft}$ of metamorphic rocks were penetrated at Kings- 3 beneath $70 \mathrm{ft}$ of basin-fill sediments. About $60 \mathrm{ft}$ of the basin-fill sediments were saturated (fig. $8 A$ and $B$ ). Metamorphic rocks penetrated by Kings- 3 had numer- 

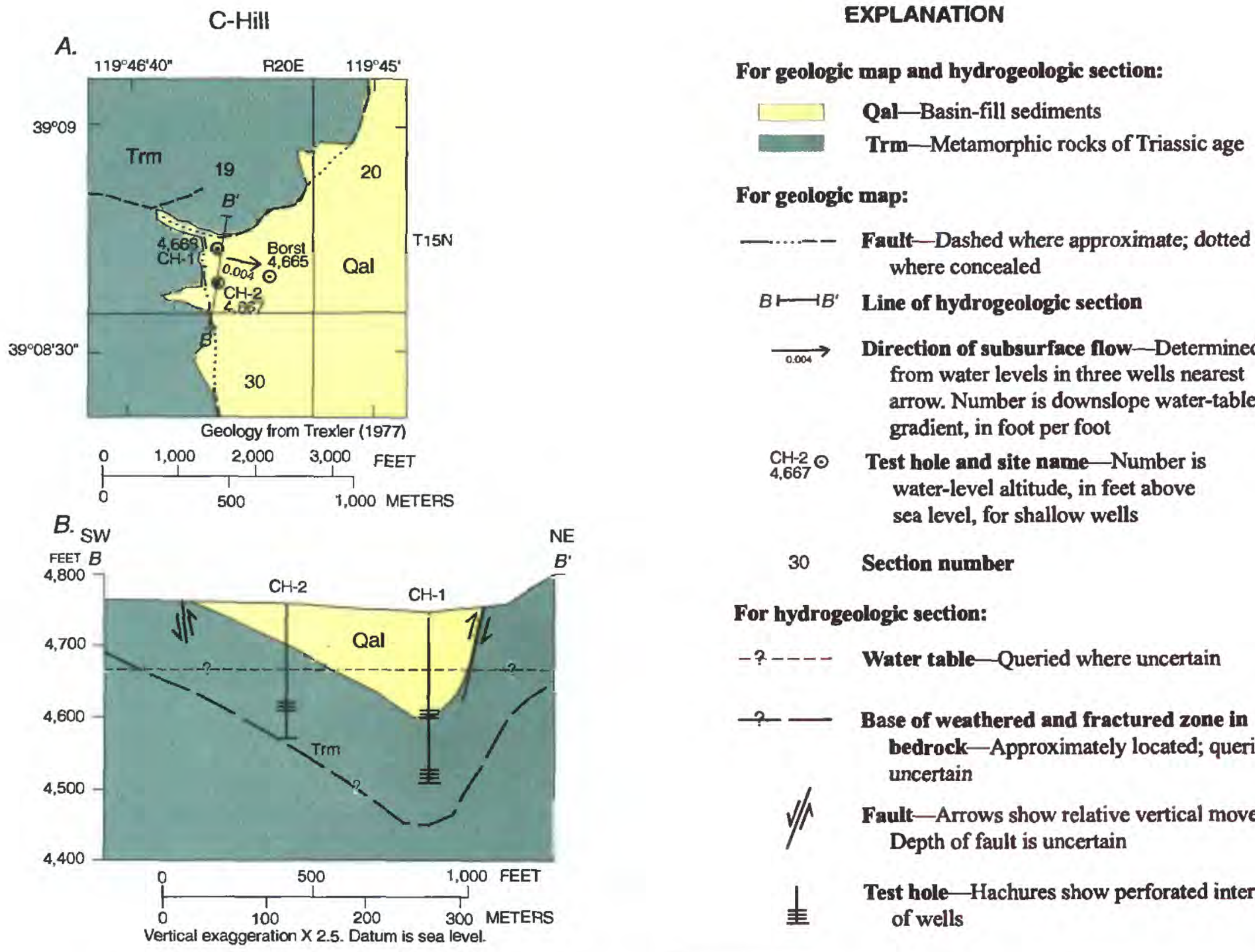

For geologic map:

\begin{tabular}{|c|c|}
\hline -.....- & $\begin{array}{l}\text { Fault-Dashed where approximate; dotted } \\
\text { where concealed }\end{array}$ \\
\hline$B \longmapsto B^{\prime}$ & Line of hydrogeologic section \\
\hline $\overrightarrow{0.004}$ & $\begin{array}{l}\text { Direction of subsurface flow-Determined } \\
\text { from water levels in three wells nearest } \\
\text { arrow. Number is downslope water-table } \\
\text { gradient, in foot per foot }\end{array}$ \\
\hline${ }_{4,667}^{\mathrm{CH}-2} \odot$ & $\begin{array}{l}\text { Test hole and site name-Number is } \\
\text { water-level altitude, in feet above } \\
\text { sea level, for shallow wells }\end{array}$ \\
\hline
\end{tabular}

30

Section number

For hydrogeologic section:

Water table-Queried where uncertain
$\begin{aligned} & \text { Base of weathered and fractured zone in } \\ & \text { bedrock-Approximately located; queried where } \\ & \text { uncertain }\end{aligned}$
Fault-Arrows show relative vertical movement.
Depth of fault is uncertain

Figure 7. Surficial geology, location of wells and cross section, and direction of subsurface flow and downslope watertable gradient (A), and cross section showing distribution of saturated and unsaturated basin-fill sediments and bedrock (B) for C-Hill watershed, Eagle Valley, Nevada. Location shown on figure 3.

ous zones of clay-filled fractures, 5-34 ft thick, alternating with zones with little clay, 2-11 ft thick. The Quill well (fig. 8A), installed prior to this study, was drilled near exposed metamorphic rock and close to a major valley-bounding fault. The total depth is $340 \mathrm{ft}$ and the well did not penetrate metamorphic rock. The drill bit may have grazed the surface of the metamorphic rock and followed a nearly vertical fault zone. The City well (fig. 8A) is an unused well drilled in 1948 for the Carson Water Company, which penetrated $217 \mathrm{ft}$ of basin-fill sediments. The Kings- 2 well (fig. $8 A$ ) was drilled for the initial phase of this study and penetrated about $160 \mathrm{ft}$ of basin-fill sediments and about $15 \mathrm{ft}$ of fractured metamorphic rocks.

The water-table gradient calculated from water levels at the shallow Kings-3, Quill, and City wells (appendix 2) was $0.050 \mathrm{ft} / \mathrm{ft}$ in a direction $57^{\circ}$ from true north (fig. 8A). A similar gradient and flow direction $\left(0.056 \mathrm{ft} / \mathrm{ft}\right.$ in a direction $51^{\circ}$ from true north) was obtained using water levels from the shallow Kings-3 and Kings- 2 wells, and the City well.

Using the mid-point of the gravel-packed intervals and water levels measured in the shallow and deep wells at Kings-3, a downward vertical gradient of 0.083 $\mathrm{ft} / \mathrm{ft}$ was obtained. The water level in the deep well was about $9.6 \mathrm{ft}$ lower than in the shallow well. This difference is greater than would be expected from the watertable gradient $(0.2 \mathrm{ft})$, as described previously. Metamorphic rocks from 130 to $140 \mathrm{ft}$ below land surface with estimated hydraulic conductivities less than 0.02 $\mathrm{ft} / \mathrm{d}$ (fig. $5 E$ ) probably impede downward flow.

From the scaled cross section (fig. $8 B$ ), the area of saturated basin-fill sediments beneath section $C-C$ ' is $59,000 \mathrm{ft}^{2}$ (table 5). If the metamorphic rocks are permeable to ground-water flow through the same thickness as penetrated by Kings- 3 (about $130 \mathrm{ft}$; fig. 8B), 


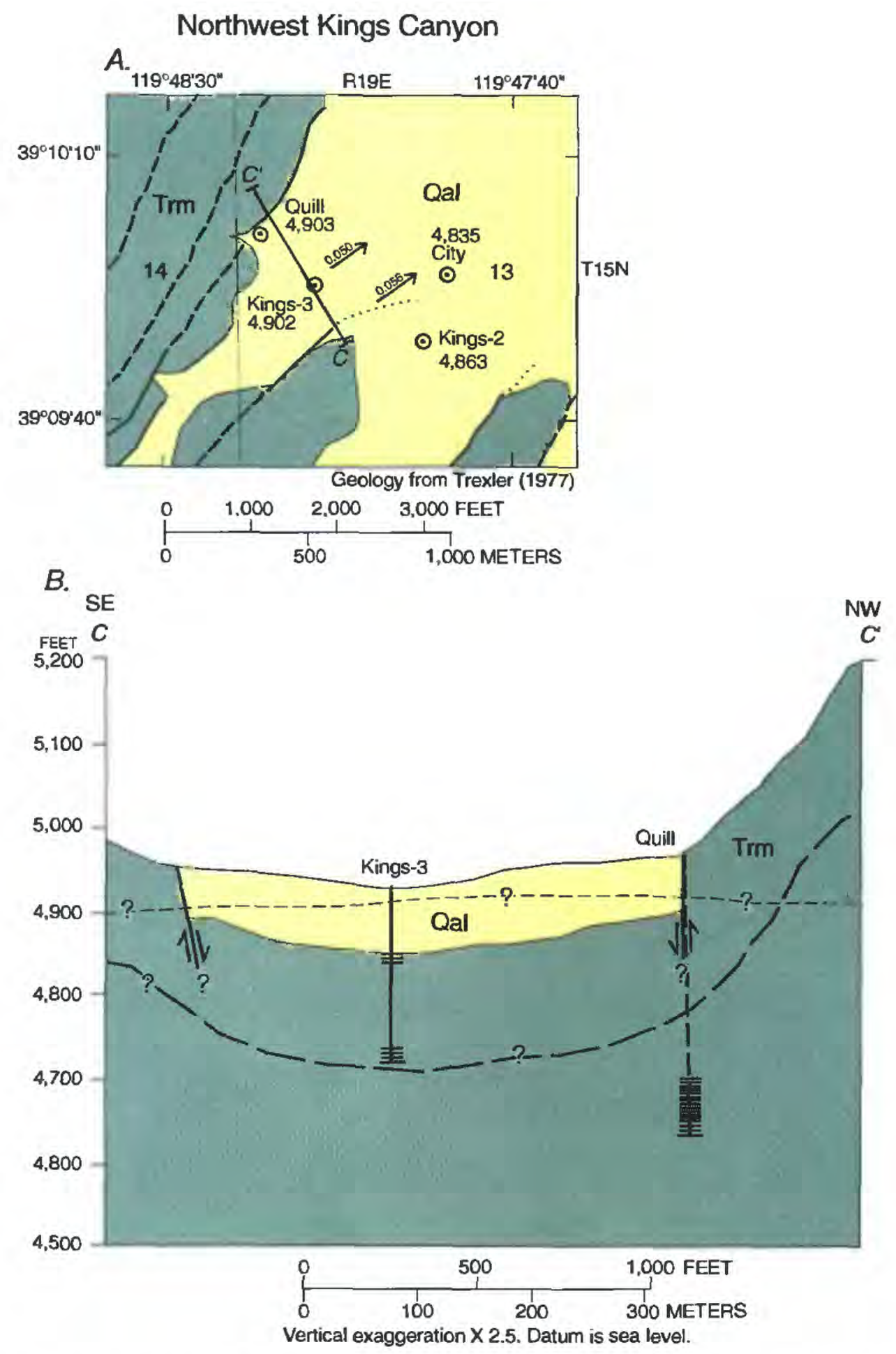

EXPLANATION

For geologic map and hydrogeologic section:

Qal-Basin-fill sediments

Trm-Metamorphic rocks of Triassic age

For geologic map:

-.....- Fault-Dashed where approximate; dotted where concealed

$C \longmapsto C^{\prime} \quad$ Line of hydrogeologic section

$\longrightarrow$ Direction of subsurface flow-Determined from water levels in three wells nearest arrow. Number is downslope water-table gradient, in foot per foot

City $\odot$ Test hole and site name- Number is water-level altitude, in feet above sea level, for shallow wells

13

Section number

For hydrogeologic section:

- ?-_-- Water table-Queried where uncertain

- B Base of weathered and fractured zone in bedrock-Approximately located; queried where uncertain

I/ Fault-Arrows show relative vertical movement. Depth of fault is uncertain

| Test hole - Hachures show perforated interval of wells

Figure 8. Surficial geology, location of wells and cross section, and direction of subsurface flow and downslope water-table gradient ( $A$ ), and cross section showing distribution of saturated and unsaturated basin-fill sediments and bedrock (B) for northwestern Kings Canyon watershed, Eagle Valley, Nevada. Location shown on figure 3.

the cross-sectional area of the metamorphic rocks with clay-filled fractures is about $222,000 \mathrm{ft}^{2}$.

Although metamorphic rocks with a hydraulic conductivity of $30 \mathrm{ft} / \mathrm{d}$ were penetrated by test hole Kings-2 (Maurer and others, 1996, p. 23), analysis of the slug tests in the shallow and deep wells at Kings-3 resulted in the same hydraulic conductivity $(0.2 \mathrm{ft} / \mathrm{d}$; table 1). This suggests that highly permeable zones in metamorphic rocks are limited in extent.

Geometric-mean hydraulic conductivities calculated for hydrogeologic units in basin-fill sediments ranged from $0.04 \mathrm{ft} / \mathrm{d}$ for clay to $3.6 \mathrm{ft} / \mathrm{d}$ for fine sand (table 3 ). The geometric-mean hydraulic conductivity for bedrock weathered to clay is $0.11 \mathrm{ft} / \mathrm{d}$ (table 4).
Estimated subsurface flow beneath northwestern Kings Canyon is small-15 acre- $\mathrm{ft} / \mathrm{yr}$ through basinfill sediments and 10 acre-ft/yr through bedrock (table 5). If metamorphic rocks along a fault mapped south of test hole Kings-3 (fig. $8 A$ ) have a higher hydraulic conductivity than that measured at Kings-3, the estimate of subsurface flow may be a minimum value.

Annual precipitation within the watershed is 740 acre-ft and average annual surface runoff is estimated to be 56 acre-ft/yr. Using the value of dissolvedchloride concentration of $1.8 \mathrm{mg} / \mathrm{L}$ for ground water and $0.4 \mathrm{mg} / \mathrm{L}$ for surface runoff, subsurface flow from the watershed is estimated to be about 150 acre-ft/yr 
(table 6). Subsurface flow estimated using the chloridebalance method is considerably larger than that estimated using Darcy's law (table 7).

Table 7. Summary of subsurface-flow estimates for instrumented watersheds, Eagle Valley, Nevada

\begin{tabular}{|c|c|c|}
\hline \multirow{2}{*}{$\begin{array}{l}\text { Watershed name, number } \\
\text { (fig. 1) }\end{array}$} & \multicolumn{2}{|c|}{$\begin{array}{l}\text { Estimated subsurface flow } \\
\text { (acre-feet per year) }\end{array}$} \\
\hline & Darcy's law & $\begin{array}{l}\text { Chloride- } \\
\text { balance } \\
\text { method }\end{array}$ \\
\hline Clear Creek, 2 & 1,200 & (2) \\
\hline C-Hill, 6 & 20 & 70 \\
\hline Kings Canyon, 9 and $10^{l}$ & 2,300 & $600-1,000$ \\
\hline Northwest Kings Canyon, 11 & 20 & 150 \\
\hline Ash Canyon, $12^{1}$ & $200-400$ & $200-500$ \\
\hline Vicee Canyon, 13 and $14^{1}$ & 300 & 400 \\
\hline Goni, 20 and 21 & 400 & $70-180$ \\
\hline Centennial Park, 24 & 30 & 20 \\
\hline
\end{tabular}

\section{Goni Watershed}

The Goni watersheds ( 20 and 21 ) are underlain by a mixture of metamorphic, basaltic, and Tertiary volcanic rocks, although basaltic rocks make up the bulk of the outcrop (fig. 3). Metamorphic rocks are found beneath the southeastern and northwestern ends of the cross section and basaltic rocks are exposed about $2,000 \mathrm{ft}$ from the southeastern end of the section (fig. 9A).

At Goni-1, about $265 \mathrm{ft}$ of basaltic rocks were penetrated beneath $37 \mathrm{ft}$ of basin-fill sediments. The basaltic rocks included zones of fractured black basalt; zones of soft red cinders; and an intervening zone of rounded, vesicular cobbles and gravel about $60 \mathrm{ft}$ thick (fig. 9B). This sequence is similar to that described by Bingler (1977) who mapped two separate Quaternary basalt formations in the watershed with a formation of cobbles underlying the uppermost basalt flow. During drilling and well installation, the test hole repeatedly collapsed, making it impossible to obtain borehole geophysical data, but a 2 -in. steel screen and casing were jetted into the zone of cobbles and gravel.

At Goni-2, $114 \mathrm{ft}$ of basin-fill sediments and about $145 \mathrm{ft}$ of metamorphic rock were penetrated. The metamorphic rock had numerous clay-filled fractures and drill cuttings often were a mixture of clay and angular metamorphic rock chips. Sections of metamorphic rock with little clay ranged from 3 to $12 \mathrm{ft}$ thick, and a 2-ft core taken from the bottom of the hole was mostly solid metamorphic rock with 1/4- to 1-in. clayfilled fractures. At Goni-3, $140 \mathrm{ft}$ of basin-fill sediments were penetrated, $60 \mathrm{ft}$ of which were saturated.

The water-table gradient calculated using water levels at the Goni-1, Goni-2, and Goni-3 wells was $0.014 \mathrm{ft} / \mathrm{ft}$ in a direction about $220^{\circ}$ from true north (fig. 9A). Using wells Goni-1 and Goni-2, which are screened in bedrock, and Goni-3, which is screened in basin-fill sediments, may cause some inaccuracy when used to estimate the gradient in basaltic rocks. However, the three wells are the only wells available to estimate flow direction and gradient near the mouth of the watershed.

Using the mid-point of the gravel-packed intervals and water levels measured in the shallow and deep wells at Goni-2 (appendix 2), a downward vertical gradient of $0.017 \mathrm{ft} / \mathrm{ft}$ was measured. The water level in the deep well was about $1.9 \mathrm{ft}$ lower than in the shallow well. This difference is greater than would be expected from the water-table gradient $(0.03 \mathrm{ft})$. This implies downward flow within the metamorphic rocks near Goni-2.

The cross section $D-D^{\prime}$ was drawn perpendicular to the direction of ground-water flow, as described below, and includes flow through the basaltic rocks that cover most of watershed 20 and the western part of watershed 21 (fig. 3). The lithologic distribution for section $D-D^{\prime}$ was drawn assuming that the cobble zone penetrated in Goni-1 is lenticular; pinching out to the southeast and present only near the test hole (fig. $9 B$ ). Also, a fault north of the cross section that is downthrown to the east with its southern extent concealed by basin-fill sediments (fig. 9A) was assumed to continue south and intersect the section between Goni-1 and Goni-2, offsetting the metamorphic rocks.

Basin-fill sediments beneath the section $D-D^{\prime}$ are entirely unsaturated. From the scaled cross section (fig. 9B), the cobble zone beneath the section has an assumed area of about $27,000 \mathrm{ft}^{2}$, and saturated basalt beneath the section has an assumed maximum thickness of about $220 \mathrm{ft}$ and an area of about $294,000 \mathrm{ft}^{2}$ (table 5). Metamorphic rocks beneath the section appear to be largely weathered to clay where fractured. Small hydraulic conductivities were measured at Goni2 , ranging from 0.009 to $0.03 \mathrm{ft} / \mathrm{d}$ for the slug tests (table 1), and a geometric-mean hydraulic conductivity of $0.02 \mathrm{ft} / \mathrm{d}$ was calculated for the entire thickness of 


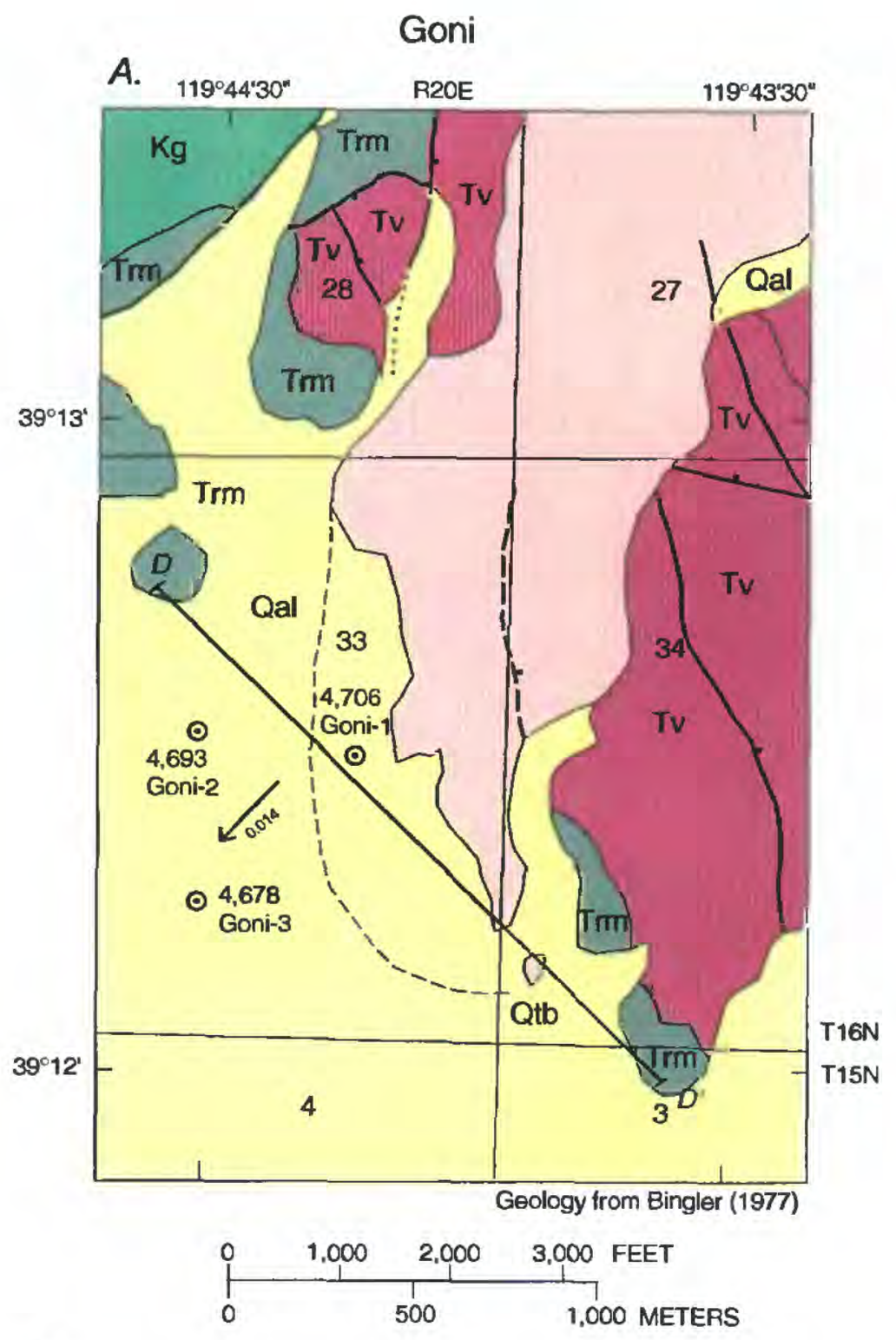

\section{EXPLANATION}

For geologic map and hydrogeologic section:

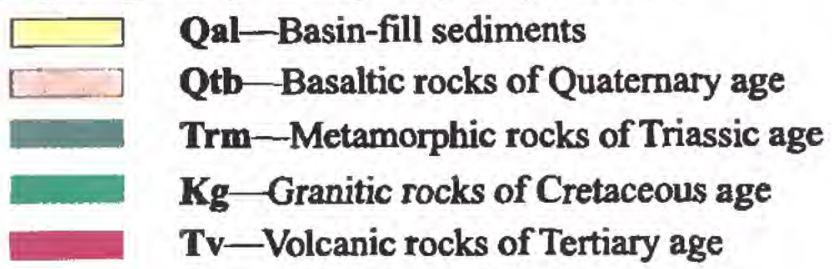

For geologic map:

-....-- Fault-Dashed where approximate; dotted where concealed. Ball on downthrown side

$D \longmapsto D^{\prime}$ Line of hydrogeologic section

- Shows prohable extent of Basaltic rocks

$\longrightarrow$ Direction of subsurface flow-Determined from water levels in three wells nearest arrow. Number is downslope water-table gradient, in foot per foot

$4,678 \odot$ Test hole and site name-Number is water-level altitude, in feet above sea level, for shallow wells

34 Section nnmber

For hydrogeologic section:

-? - - - Water table- Queried where uncertain

?- Base of weathered and fractured zone in bedrock-Approximately located; queried where uncertain

I/A Fault-Arrows show relative vertical movement. Depth of fault is uncertain

B.

NW

I Test hole- Hachures show perforated

圭 interval of wells

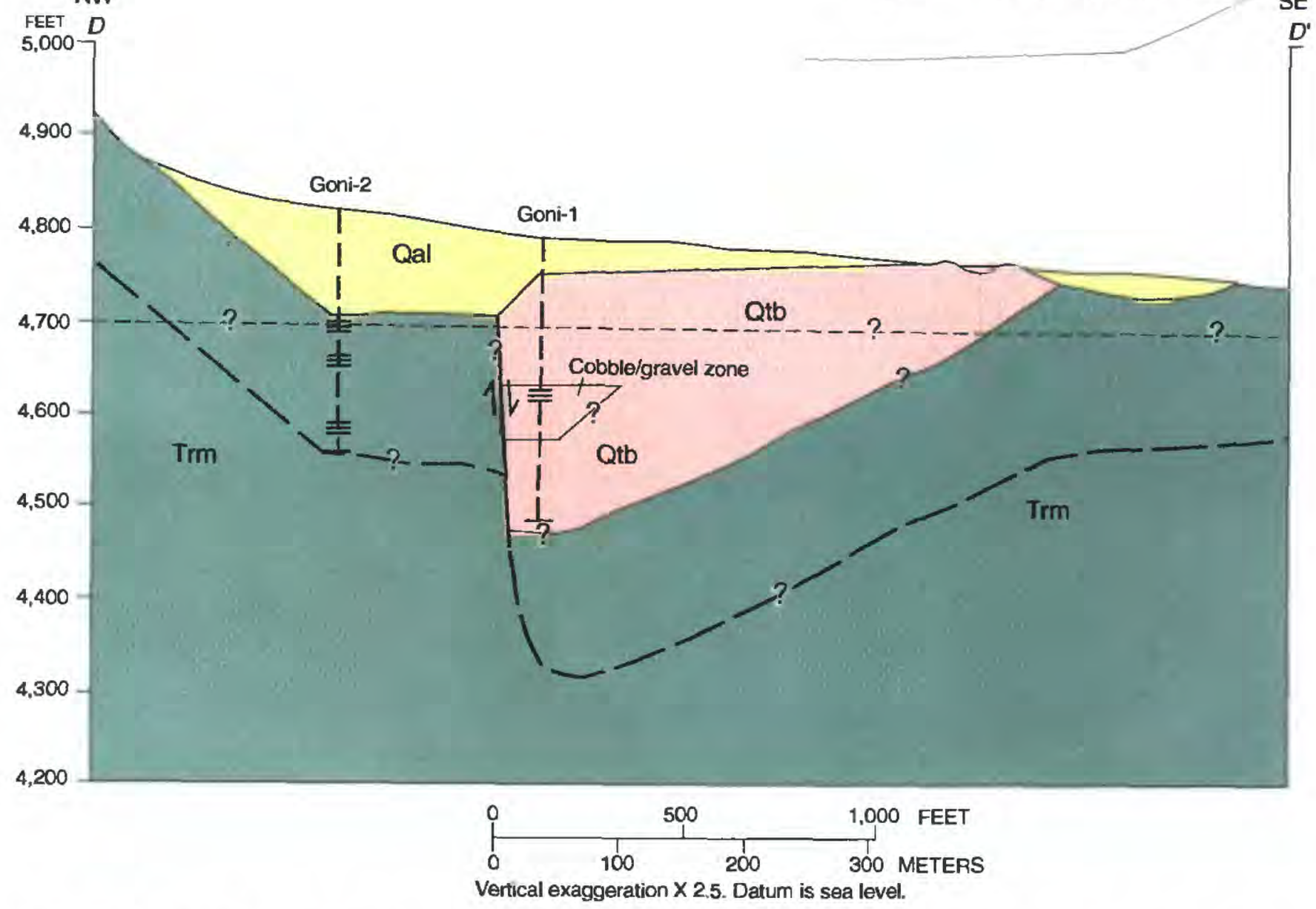

Figure 9. Surficial geology, location of wells and cross section, and direction of subsurface flow and downslope water-table gradient $(A)$, and cross section showing distribution of saturated and unsaturated basin-fill sediments and bedrock (B) for Goni watershed, Eagle Valley, Nevada. Location shown on figure 3. 
metamorphic rocks (table 4). If flow takes place through the same thickness of metamorphic rocks penetrated at Goni-2 (145 ft), the area is about $780,000 \mathrm{ft}^{2}$ (table 5).

Because no borehole resistivity data were obtained from Goni-1, geometric-mean hydraulic conductivities could not be calculated for the basaltic rocks or the cobble zone beneath the section. Also, both the cobble zone and basaltic rocks probably do not extend a great distance downgradient from section $D-D^{\prime}$ and do abut basin-fill sediments penetrated at Goni-3 (fig. 9A). Flow through the cross section would be overestimated using the hydraulic conductivities estimated for the cobble zone (300-500 ft/d; table 1), because flow through the cobble zone is limited by the lower hydraulic conductivity of the basin-fill sediments ( $30 \mathrm{ft} / \mathrm{d})$. An equivalent hydraulic conductivity was calculated for all aquifer materials between Goni- 1 and Goni-3 using the following equation modified from Freeze and Cherry (1979, p. 34):

$$
K_{e}=X_{1}+X_{2} /\left[\left(X_{1} / K_{1}\right)+\left(X_{2} / K_{2}\right)\right]
$$

where $K_{e}$ is the equivalent hydraulic conductivity beneath the cross section, in feet per day;

$X_{1}$ is the horizontal distance from Goni-1 to the edge of the basalt or cobble zone, in feet;

$X_{2}$ is the horizontal distance from the edge of the basalt or cobble zone to Goni-3, in feet;

$K_{l}$ is the hydraulic conductivity of the basalt or cobble zone, in feet per day; and

$K_{2}$ is the hydraulic conductivity of the basin-fill sediments, in feet per day.

On the basis of lithologic units penetrated at Goni2 and Goni-3 and the outcrop pattern of the basaltic rocks, both basaltic rocks and the cobble zone are assumed to extend about $500 \mathrm{ft}$ from Goni-1, with basinfill sediments present for about $1,500 \mathrm{ft}$ between the two wells (fig. 9A). The hydraulic conductivities estimated from the slug tests of the cobble zone at Goni- 1 and basaltic rocks at CP-1 (300-500 ft/d and $3 \mathrm{ft} / \mathrm{d}$, respectively), were used for $K_{1}$ in equation 8 , with $X_{1}$ equal to $500 \mathrm{ft}$. The hydraulic conductivity estimated from the slug test of basin-fill sediments at Goni-3 (30 ft/d), was used for $K_{2}$, with $\mathrm{X}_{2}$ equal to $1,500 \mathrm{ft}$. The resulting equivalent hydraulic conductivities were about $40 \mathrm{ft} / \mathrm{d}$ for the cobble zone and about $10 \mathrm{ft} / \mathrm{d}$ for the basaltic rocks (table 5). About 120 acre-ft/yr is estimated for flow through the cobble zone, and about 300 acre- $\mathrm{ft} / \mathrm{yr}$ is estimated for flow through the basaltic rock.

Flow through the metamorphic rock weathered to clay can be reasonably estimated from their geometricmean hydraulic conductivity because they probably extend well beyond the cross section. Flow estimated through the metamorphic rocks is 1 acre- $\mathrm{ft} / \mathrm{yr}$, for a total of about 400 acre- $\mathrm{ft} / \mathrm{yr}$ beneath the section. This could be a minimum value if basaltic rocks extend to depths greater than that penetrated by Goni-1.

Annual precipitation in the two Goni watersheds is 3,300 acre- $\mathrm{ft}$ and average annual surface runoff is estimated to be 155 acre-ft (table 6). A range of estimated subsurface flow was calculated using the chloride-balance method, because of uncertainties in the actual dissolved-chloride concentration of ground water near the cross section. Ground water sampled at Goni- 1 had $17 \mathrm{mg} / \mathrm{L}$ dissolved-chloride concentration, which seems anomalously high compared to other sampled watersheds. This anomaly could be caused by infiltration from a nearby septic tank, or upflow of geothermal water from Carson Hot Springs about $1 \mathrm{mi}$ to the southwest. Using the value of $17 \mathrm{mg} / \mathrm{L}$ for the dissolved-chloride concentration in ground water and $0.4 \mathrm{mg} / \mathrm{L}$ for the dissolved-chloride concentration in runoff, subsurface flow is calculated to be 70 acre-ft/yr (table 6). If the dissolved-chloride concentration in ground water sampled in the Centennial Park well $(7.2 \mathrm{mg} / \mathrm{L})$ is assumed to be more representative of subsurface flow through the basaltic rocks, an estimate of about 180 acre-ft/yr was determined for subsurface flow from the Goni watershed (table 6). Both values are less than that estimated using Darcy's law (table 7). As discussed in the following section, ground water sampled in the Centennial Park well also could be affected by treated effluent applied for irrigation. Thus, 180 acre-ft/yr should be considered a minimum value.

\section{Centennial Park Watershed}

The Centennial Park watershed (24) also is underlain by a mixture of metamorphic rocks, Quaternary basaltic rocks, and Tertiary volcanic rocks (fig. 3). Basaltic rocks crop out on the eastern side of the cross section, and about $70 \mathrm{ft}$ of basalt was penetrated in the Centennial Park test hole (CP-1) beneath about $60 \mathrm{ft}$ of basin-fill sediments (fig. 10A and $B$ ). The test hole also penetrated about $10 \mathrm{ft}$ of metamorphic rocks, which underlie the basaltic rocks and crop out on the western side of the section.

The water-table gradient calculated from water levels at shallow wells GC-8 and GC-10 (fig. 10A) at the Eagle Valley Golf Course, and the Centennial Park well (appendix 2) was $0.011 \mathrm{ft} / \mathrm{ft}$ in a direction about $180^{\circ}$ from true north (fig. $6 A$ ). These values are approximate because the Centennial Park well is screened in 


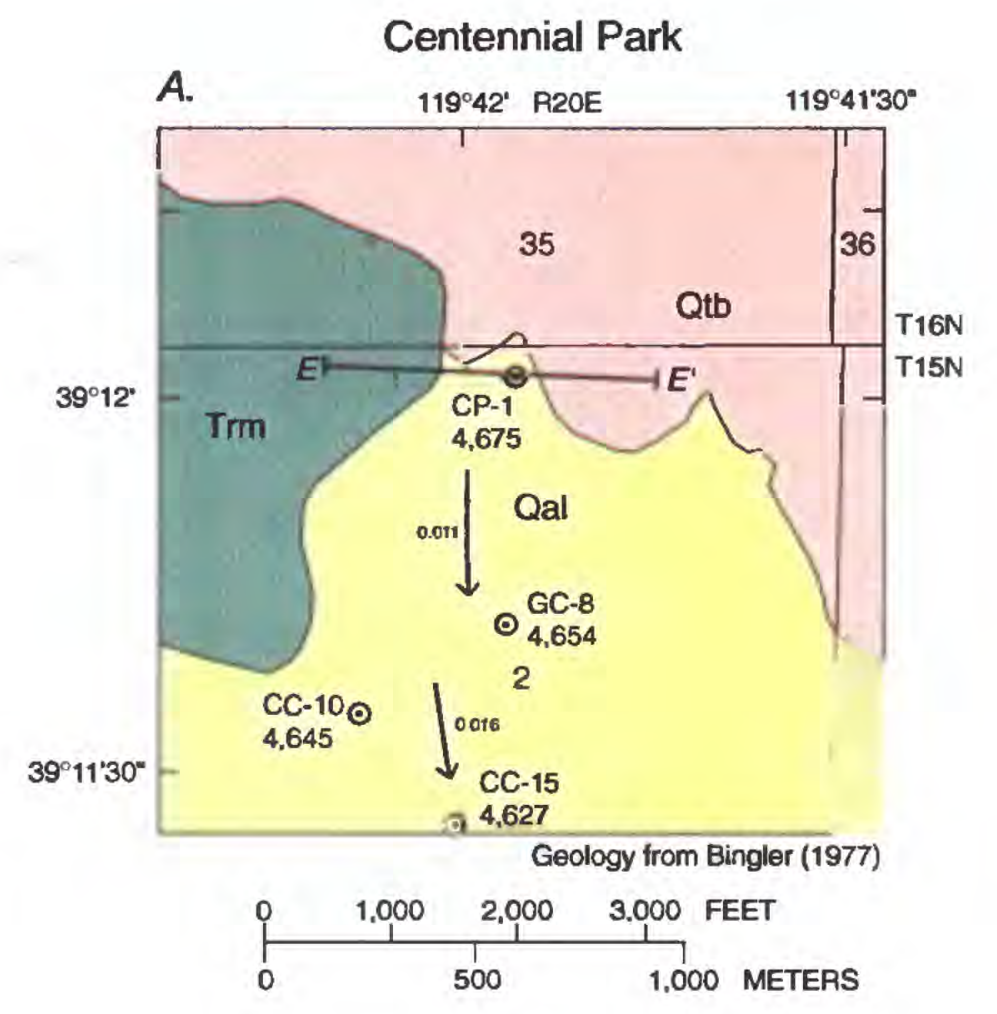

EXPLANATION

For geologic map and hydrogeologic section:

Qal-Basin-fill sediments

Qtb-Basaltic rocks of Quaternary age

Trm-Metamorphic rocks of Triassic age

For geologic map:

$E \longmapsto E$ Line of hydrogeologic section

$\longrightarrow$ Direction of subsurface flow-Determined from water levels in three wells nearest arrow. Number is downslope water-table gradient, in foot per foot

Test hole and site name - Number is water-level altitude, in feet above sea level, for shallow wells

${ }_{4,654} \mathrm{O}$ Section number

For hydrogeologic section:

$-?----$ Water table-Queried where uncertain

$\rightarrow-$ Base of weathered and fractured zone in bedrock-Approximately located; queried where uncertain

| Test hole-Hachures show perforated 圭 interval of wells

B.

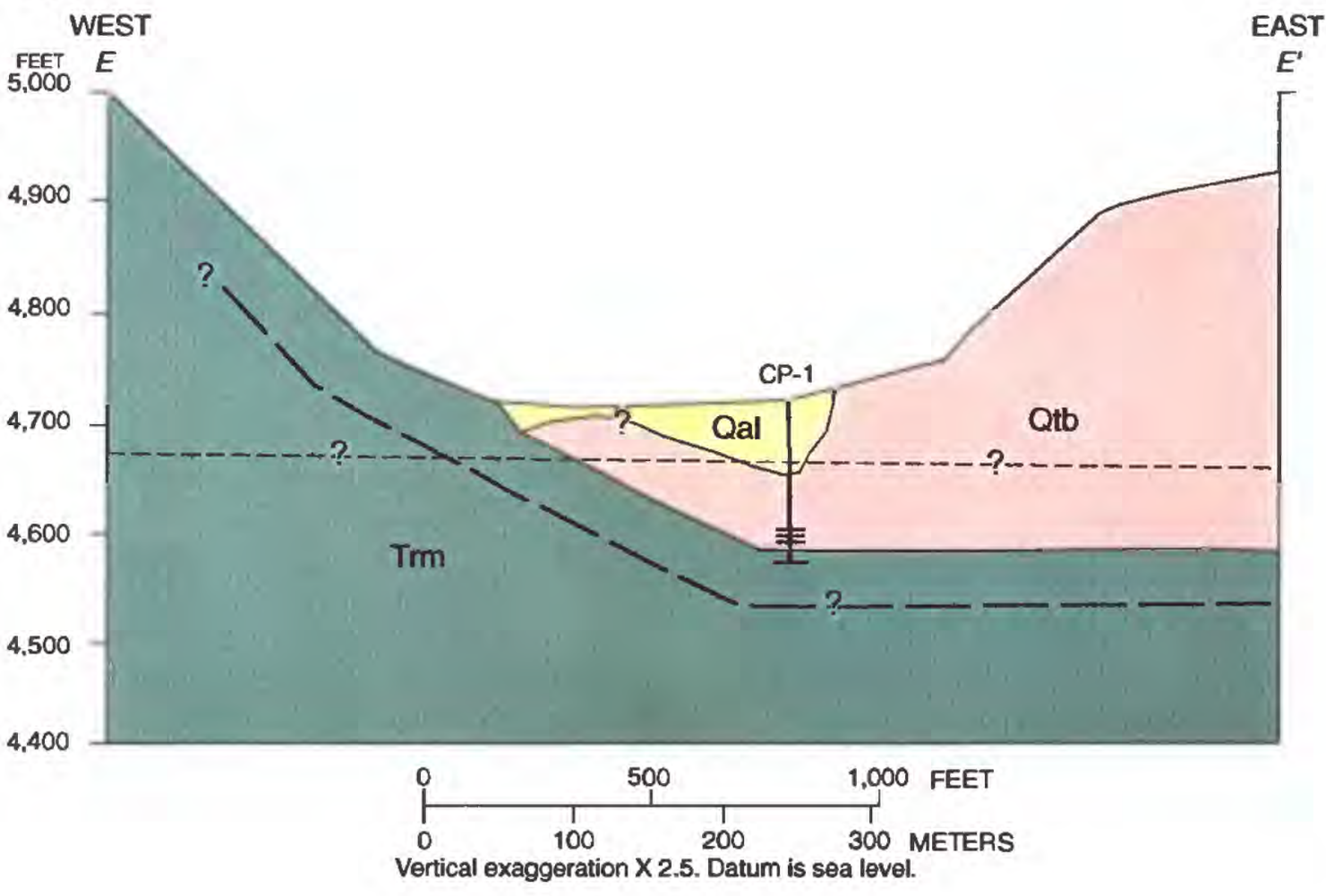

Figure 10. Surficial geology, location of wells and cross section, and direction of subsurface flow and downslope water-table gradient $(A)$, and cross section showing distribution of saturated and unsaturated basin-fill sediments and bedrock $(B)$ for Centennial Park watershed, Eagle Valley, Nevada. Location shown on figure 3. 
bedrock, whereas GC-8 and GC-10 are screened in basin-fill sediments. Using water levels in wells GC-8, GC-10, and CC-15 (fig. 10A), an unused test hole installed by Carson City, a gradient of $0.016 \mathrm{ft} / \mathrm{ft}$ in a direction of about $170^{\circ}$ from true north was calculated. This suggests that the value calculated using the Centennial Park well is reasonable.

Only a small area of basin-fill sediments beneath the cross section $E-E^{\prime}$ is saturated (fig. $10 B$ ). Flow through these sediments is considered to be insignificant. As determined from the scaled cross section, saturated basalt beneath the section has an area of about $108,000 \mathrm{ft}^{2}$ (table 5). The 6-in. diameter Odex casing used to drill the test hole allowed installation of only one well casing, which was placed in the basalt. Therefore, measurements of aquifer characteristics of the metamorphic rocks could not be made. During drilling, metamorphic rocks underlying the basalt were found to be fractured with little clay content, and appeared to be producing additional water to the test hole when air lifted (Jack E. Hennagan, U.S. Geological Survey, oral commun., 1996), indicating that the metamorphic rocks could be fairly permeable. If the fractured zone near the upper surface of the metamorphic rocks is assumed to be $50 \mathrm{ft}$ thick, similar to fractured zones found on the western side of Eagle Valley (Maurer and others, 1996, p. 19), the area of saturated and fractured metamorphic rocks is about $86,000 \mathrm{ft}^{2}$ (table 5).

A hydraulic conductivity of $3 \mathrm{ft} / \mathrm{d}$ was estimated from analysis of the slug test of basaltic rocks adjacent to the gravel-packed interval in CP-1 (table 1). Because no other test holes were drilled in the Centennial Park watershed, available data are insufficient to develop a correlation between borehole resistivity and hydraulic conductivity and therefore, a geometric-mean hydraulic conductivity cannot be determined.

Using the hydraulic conductivity value of $3 \mathrm{ft} / \mathrm{d}$ for the basalt from the slug test, an estimate of 30 acre$\mathrm{ft} / \mathrm{yr}$ was determined for subsurface flow (table 5). Because the metamorphic rocks beneath the cross section could not be tested, they are assumed to have low hydraulic conductivity and flow through the unit is assumed to be minor. Thus, a total of $30 \mathrm{acre}-\mathrm{ft} / \mathrm{yr}$ is estimated beneath the cross section. This is a minimum value if the metamorphic rocks do transmit ground water.

Annual precipitation within the Centennial Park watershed is about 370 acre- $\mathrm{ft}$ and average annual surface runoff is estimated to be 10 acre- $\mathrm{ft}$ (table 6). Using a dissolved-chloride concentration of $7.2 \mathrm{mg} / \mathrm{L}$ for ground water and $0.4 \mathrm{mg} / \mathrm{L}$ for surface runoff from the watershed, subsurface flow is estimated to be about $20 \mathrm{acre}-\mathrm{ft} / \mathrm{yr}$ (table 6), which is similar to the estimate obtained using Darcy's law (table 7). However, treated effluent is used to irrigate athletic fields $400 \mathrm{ft}$ from CP1 and could be a source for chloride. Thus, 20 acre-ft/yr should be considered a minimum value. Samples from wells installed in the basalt upgradient from all potential sources of chloride would allow refinement of the estimates of subsurface flow.

\section{ESTIMATES OF SUBSURFACE FLOW FROM UNINSTRUMENTED WATERSHEDS}

To estimate subsurface flow from uninstrumented watersheds, the percentage of annual precipitation that was estimated to be subsurface flow from instrumented watersheds was applied to the annual precipitation for nearby uninstrumented watersheds of similar geology (table 8 and fig. 3). The percentage estimated for the Clear Creek watershed ( 5 percent) was used for watersheds $1-4$; the percentage range estimated for the CHill watershed (2-7 percent) was used for watersheds 5-8 and 27; the percentage range estimated for the Vicee Canyon watershed, (13-17 percent, Maurer and others, 1996, p. 34), was used for watersheds 15-19; the percentage range estimated for the Goni watershed (2-12 percent) was used for watershed 22 ; and the percentage range estimated for the Centennial Park watershed (5-8 percent) was used for watersheds 23-26.

The resulting estimate of total subsurface flow to Eagle Valley ranges from 3,200 to 6,100 acre- $\mathrm{ft} / \mathrm{yr}$ (table 8). This range is equivalent to a continuous flow of 4 to $8 \mathrm{ft}^{3} / \mathrm{s}$ at the perimeter of the valley floor, and is considered to be a reasonable range for recharge from subsurface flow to basin-fill aquifers beneath Eagle Valley.

\section{ESTIMATES OF WATER YIELD}

The range in estimates of subsurface flow from watersheds tributary to the Eagle Valley Hydrographic Area, combined with estimates of surface runoff, provide a range in estimates of water yield for the area (table 8). Runoff measured at gaging stations on Kings Canyon, Ash Canyon, Vicee Canyon, and Clear Creeks was adjusted to long-term mean annual runoff on the basis of measured runoff from the West Fork Carson River at Woodfords, Calif. The mean annual runoff for the period of record in each gaged watershed was divided by the ratio of mean annual runoff of the West Fork Carson River at Woodfords, Calif., for the period 
of record in each watershed to the long-term mean annual runoff recorded for the West Fork Carson River at Woodfords (period of record from 1900-07, 1910-11, and 1938-95). Adjusted mean annual runoff for this period of record for Kings Canyon, Ash Canyon, Vicee Canyon, and Clear Creeks is 1,200, 2,600, 200, and 4,000 acre-ft/yr, respectively (table 8).

Estimates of runoff from ungaged watersheds were made using the method developed by Moore (1968, p. 33). This method applies a runoff value for altitude zones of $1,000-\mathrm{ft}$ intervals above $5,000 \mathrm{ft}$, with varying runoff values for different regions in Nevada. The area between 1,000-ft contours was determined for each watershed. Each area was then multiplied by the corresponding runoff value given by Moore (1968, table 3 ). From the unnumbered plate of Moore (1968), region $\mathrm{D}$ was used for watersheds draining the Carson Range (watersheds 1-17, fig. 1) and region $C$ for watersheds draining the Virginia Range and Prison Hill (watersheds 18-27).

Mean annual runoff estimated using this method for Kings Canyon, Ash Canyon, Vicee Canyon, and Clear Creeks is 1,100, 2,100,300, and 3,800 acre-ft/yr, respectively (table 8 , values in parentheses). Moore's (1968) method of estimating runoff appears to provide a reasonable estimate for gaged watersheds and therefore is assumed to provide a good approximation of runoff from ungaged watersheds.

The total water yield for Eagle Valley ranges from $12,000 \mathrm{acre}-\mathrm{ft} / \mathrm{yr}$ to $15,000 \mathrm{acre}-\mathrm{ft} / \mathrm{yr}$ (table 8 ), which is greater than the water yield of $9,000 \mathrm{acre}-\mathrm{ft} / \mathrm{yr}$ estimated by Arteaga and Durbin (1979, p. 14). This difference is because Arteaga and Durbin (1979, p. 15) assumed that runoff from the perennial streams of Kings Canyon, Ash Canyon, and Clear Creeks represented the entire water yield from these watersheds because they were underlain by bedrock. As shown in table 8 and by Maurer and others (1996, p. 35), the combined subsurface flow estimated from these three watersheds is at least 2,000 acre$\mathrm{ft} / \mathrm{yr}$ (table 7). The estimate of water yield obtained by Arteaga and Durbin (1979) for each watershed and for the entire valley is similar to the estimate of surface runoff obtained using Moore's (1968) method and, on the basis of current study results and those of Maurer and others (1996), is more representative of runoff alone.

The estimates of water yield represent from 21 to 27 percent of the annual precipitation, with subsurface flow totaling from 6 to 11 percent, and surface runoff totaling 16 percent (table 8). Therefore, 73-79 percent of the precipitation on the watersheds is lost to evaporation or transpiration. This amount is much greater than the 20-30 percent lost to evaporation and transpiration as measured in an alpine watershed by Kattlemann and Elder (1991, p. 1559). The alpine watershed is covered mostly by bare rock with small patches of soil and vegetation (Marks and others, 1992, p. 3029), whereas watersheds surrounding Eagle Valley are largely covered by soils and stands of vegetation.

Of the total water yield, basin-fill aquifers beneath Eagle Valley are recharged by subsurface flow and runoff from each watershed that infiltrates to the water table as streams cross alluvial fans. Part of the total yield is lost on the valley floor to evaporation and transpiration by plants, and part leaves the hydrographic area as surface-water flow to the Carson River or subsurface ground-water flow beneath the boundary of the hydrographic area. Basin-fill aquifers also may be recharged by infiltration of precipitation on the valley floor, and infiltration of water used to irrigate fields and lawns.

To determine if a relation exists between precipitation, water yield, and surface runoff, the annual volumes of precipitation, surface runoff, and the average water yield from the range estimated in table 8 (acrefeet per year) were divided by the area (in acres) of each instrumented watershed to account for differences in area. These mean rates were converted to inches per year for comparison purposes (table 9). Relations between mean water yield and mean precipitation, and between mean surface runoff and mean precipitation were determined and developed for the eight instrumented watersheds.

Simple least-squares regressions of mean water yield and surface runoff as dependent variables and mean precipitation as the independent variable were done. The best regression model was produced when all values were transformed to $\log _{10}$ values, producing exponential relations (fig. 11).

The regression model of the $\log _{10}$ transformed values for mean water yield and precipitation has a coefficient of determination $\left(\mathrm{r}^{2}\right)$ of 0.93 (fig. 11A). The regression model of non-transformed values has an $r^{2}$ of 0.85 . The equation that best approximates the range in mean water yield to mean precipitation for the eight instrumented watersheds is:

$$
Y_{m}=0.0029 P_{m}^{2.43}
$$

where $Y_{m}$ is the mean annual water yield, in inches per year, and

$P_{m}$ is the mean annual precipitation, in inches per year. 


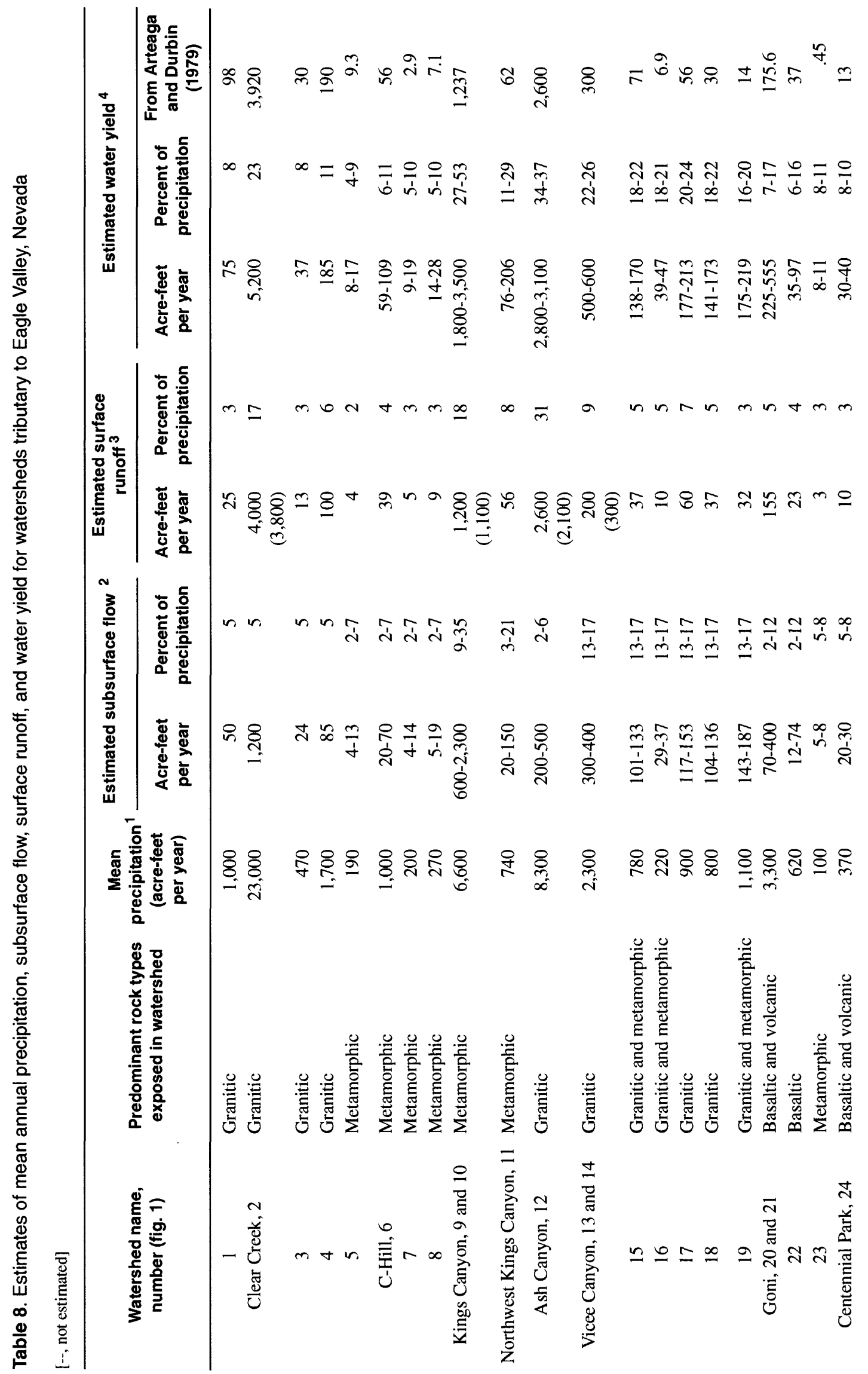




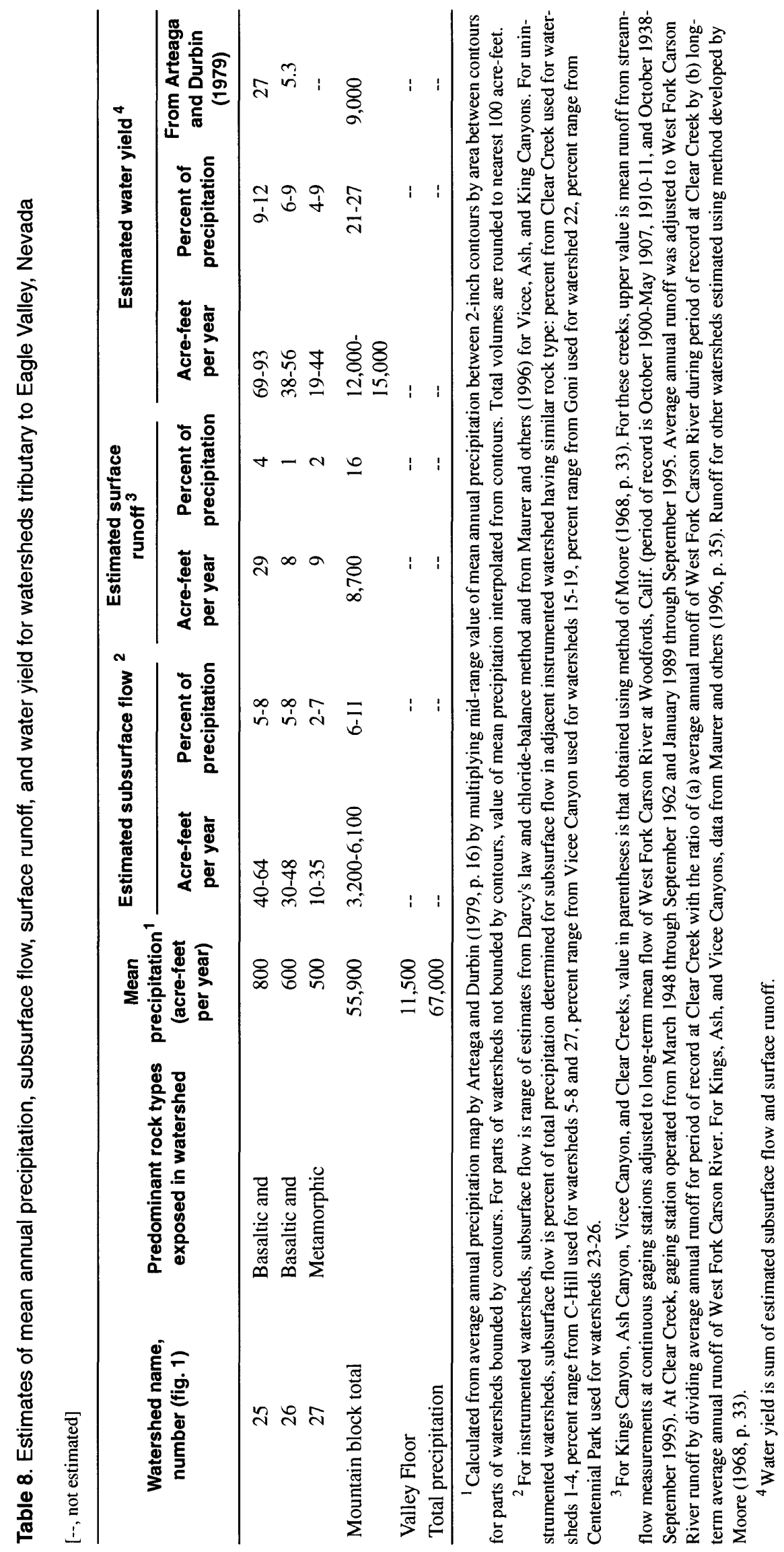


Table 9. Watershed area and mean annual precipitation, surface runoff, and water yield for instrumented watersheds, Eagle Valley, Nevada

\begin{tabular}{|c|c|c|c|c|}
\hline $\begin{array}{l}\text { Watershed name, number } \\
\text { (fig. 1) }\end{array}$ & Watershed area ${ }^{1}$ & $\begin{array}{c}P(m) \\
\text { Mean } \\
\text { precipitation } 2 \\
\text { (inches) }\end{array}$ & $\begin{array}{c}R(\mathbf{m}) \\
\text { Mean runoff }^{3} \\
\text { (inches) }^{3}\end{array}$ & $\begin{array}{c}Y(\mathbf{m}) \\
\text { Mean water } \\
\text { yield }{ }^{4} \\
\text { (inches) }\end{array}$ \\
\hline Clear Creek, 2 & 9,880 & 27.9 & 4.86 & 6.32 \\
\hline C-Hill, 6 & 940 & 12.8 & 0.50 & 1.07 \\
\hline Kings Canyon, 9 and 10 & 3,260 & 24.3 & 4.42 & 9.76 \\
\hline Northwestern Kings Canyon, 11 & 570 & 15.6 & 1.18 & 2.97 \\
\hline Ash Canyon, 12 & 3,370 & 29.6 & 9.26 & 10.5 \\
\hline Vicee Canyon, 13 and 14 & 1,300 & 21.2 & 1.85 & 5.08 \\
\hline Goni, 20 and 21 & 2,830 & 14.0 & 0.66 & 1.65 \\
\hline Centennial Park, 24 & 390 & 11.4 & 0.31 & 1.08 \\
\hline
\end{tabular}

Applying equation 9 to all watersheds tributary to Eagle Valley results in a total predicted water yield of about 15,000 acre- $\mathrm{ft} / \mathrm{yr}$. This is similar to the high estimate presented in table 8 , in large part, because yield predicted from equation 10 for Clear Creek is greater than that estimated using Darcy's law (see fig. 11A).

The greater predicted yield suggests that the estimated yield for Clear Creek is less than that expected for the mean precipitation in the watershed as compared with other watersheds. As stated previously, subsurface flow estimated for Clear Creek could be low if more ground water flows (1) across the southern watershed/hydrographic area boundary or (2) at depths greater than that assumed permeable to flow beneath the cross section. An alternative explanation might be the differing amounts of vegetation that consume precipitation. Areas covered by forest in the instrumented watersheds were determined by planimetering forested areas shown on 15-minute topographic maps. The area covered by forest in each watershed was about 60 percent for Clear Creek, about 50 percent for Vicee and Ash Canyon, and 30 and 20 percent for southeastern Kings and northwestern Kings Canyons, respectively. Thus, a greater portion of the precipitation could be consumed by evapotranspiration in the Clear Creek watershed than in the other watersheds.

In addition, figure $11 A$ shows that the low estimate of yield for Kings Canyon, when compared with yield estimated from other instrumented watersheds, could be the more reasonable value. The high estimate of yield for Kings Canyon is based on subsurface flow estimated using Darcy's law, with a substantial part of the flow estimated through metamorphic rocks with open fractures (Maurer and others, 1996, p. 30). Drilling for this study has shown that metamorphic rocks with open fractures are probably limited in extent, and their cross-sectional area may not be as great as initially estimated.

The regression model of the $\log _{10}$ transformed values for mean annual surface runoff from only the four watersheds with gaged streamflow (fig. 11B) has an $\mathrm{r}^{2}$ of 0.91 . Estimated runoff from the instrumented watersheds without gaged streamflow plots fairly close to the best-fit curve (fig. $11 B$ ). The equation that best approximates the relation of mean runoff to mean precipitation is:

$$
R_{m}=0.0000035 P_{m}^{4.34},
$$

where $R_{m}$ is mean annual surface runoff, in inches per year.

Applying equation 10 to all watersheds tributary to Eagle Valley results in a total predicted runoff of 9,300 acre- $\mathrm{ft} / \mathrm{yr}$. Estimated runoff is 8,700 acre- $\mathrm{ft} / \mathrm{yr}$ (table 8). Equation 10 overestimates runoff, again, in large part because predicted surface runoff from Clear Creek is about 1,000 acre- $\mathrm{ft} / \mathrm{yr}$ more than gaged runoff. This also suggests that, compared to other instrumented watersheds, either a greater part of the precipitation leaves as subsurface flow or a greater part is consumed by evapotranspiration. Additional wells 
A.

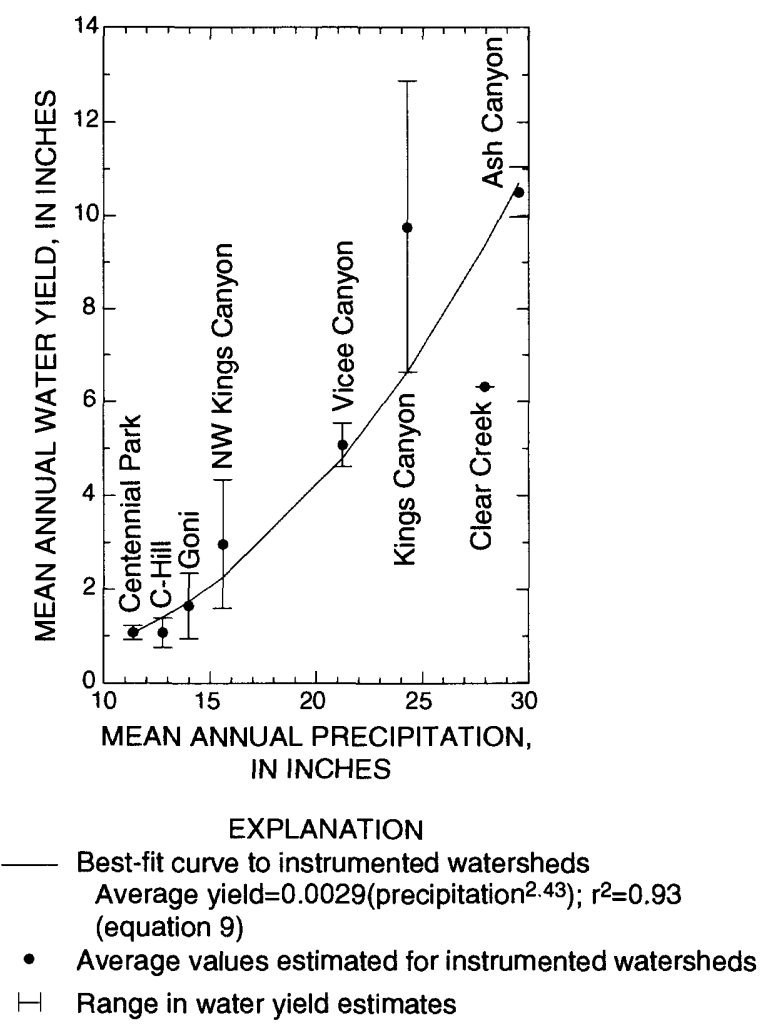

B.

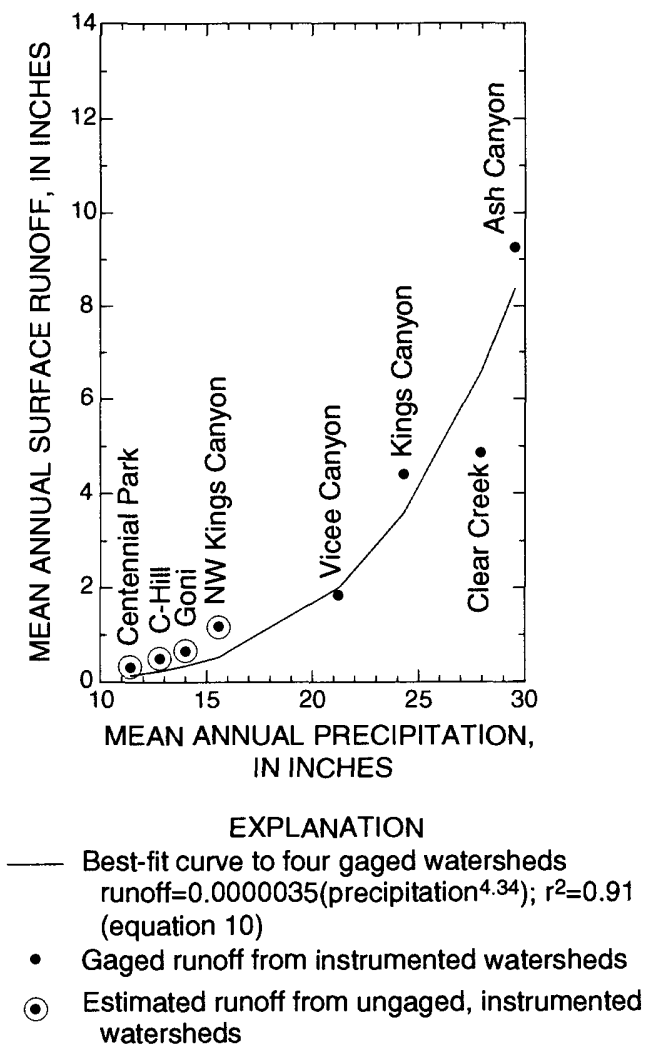

Figure 11. Relation between mean annual water yield $(A)$ and mean annual surface runoff $(B)$ to mean annual precipitation for instrumented watersheds, Eagle Valley, Nevada.

along the southern boundary of the watershed would provide information that could be used to evaluate the potential for subsurface flow.

The equations developed for water yield and surface runoff are limited in application to Eagle Valley and cannot be directly transferred to other areas of Nevada. Additional data from other hydrographic areas could be used to test and refine the coefficients of the equations. Following such testing, the equations would be useful in estimating water yield, surface runoff, and subsurface flow from watersheds tributary to other hydrographic areas along the eastern slope of the Sierra Nevada.

\section{SUMMARY AND CONCLUSIONS}

Continued population growth of Carson City, the capital of Nevada, is increasing the demand for municipal water. Carson City covers much of the valley floor in Eagle Valley, which lies along the eastern side of the Carson Range in northwest Nevada. The Virginia Range bounds the northern side of the valley.
The Carson Range is composed of granitic and metamorphic rocks, while volcanic rocks cover much of the eastern part of the Virginia Range. The basin-fill sediments beneath Eagle Valley form the principal aquifer for ground-water supply. Flow in the basin-fill aquifer is generally from the Carson Range eastward through the valley toward the Carson River.

In 1994, the U.S. Geological Survey, in cooperation with Carson City Utilities Department, studied subsurface flow from three watersheds on the western side of the valley (Vicee, Ash, and Kings Canyons). In 1996, the U.S. Geological Survey, in cooperation with Carson City Utilities Department and the Washoe Tribe of Nevada and California, began the second phase of the study to determine subsurface flow from five additional watersheds, and to estimate subsurface flow and water yield from all watersheds tributary to Eagle Valley.

Test holes were drilled along cross sections across the mouths of five watersheds, informally named Clear Creek, C-Hill, northwestern Kings Canyon, Goni, and Centennial Park. Data from the test holes and wells 
installed in them were used to estimate subsurface flow as calculated by Darcy's law from the measured hydraulic gradient across the section and the distribution, saturated thickness, and geometric-mean hydraulic conductivity of basin-fill sediments and bedrock beneath the section. The dissolved-chloride concentrations of precipitation, ground water, and surface water were used to provide an independent estimate of subsurface flow using the chloride-balance method where possible.

The basin-fill sediments and bedrock beneath each cross section were divided into hydrogeologic units on the basis of hydraulic conductivity, which was estimated for the test hole at $0.1-\mathrm{ft}$ intervals. The distribution of hydraulic conductivity in each test hole was determined from electrical resistivity logs of the hole correlated to hydraulic conductivity determined from slug tests of the wells. A geometric-mean hydraulic conductivity and thickness were then calculated for each hydrogeologic unit.

The accuracy of estimates of subsurface flow using Darcy's law is limited by the control points available from mapped geology and test holes that define the geometry and area of basin-fill sediments and bedrock beneath the cross sections. The assumptions that borehole resistivity provides a reasonable estimate of the distribution of hydraulic conductivity and that this distribution can be extrapolated across the entire cross section also limit the accuracy of the estimates. If bedrock hydrogeologic units are permeable at depths greater than that penetrated by the test holes, estimates of subsurface flow may be minimum values. The accuracy of estimates made using the chloride-balance method are limited by the assumptions that all chloride in ground water and surface water is from precipitation and dry fallout, and that the dissolved-chloride concentrations used for precipitation, ground water, and surface water are reasonably representative of average values.

Hydraulic gradients measured across the cross sections were $0.015 \mathrm{ft} / \mathrm{ft}$ at Clear Creek, $0.004 \mathrm{ft} / \mathrm{ft}$ at C-Hill, $0.05 \mathrm{ft} / \mathrm{ft}$ at northwestern Kings Canyon, 0.014 $\mathrm{ft} / \mathrm{ft}$ at Goni, and $0.011 \mathrm{ft} / \mathrm{ft}$ at Centennial Park. Geometric-mean hydraulic conductivities estimated for basin-fill sediments range from less than $0.04 \mathrm{ft} / \mathrm{d}$ for clay in the Goni, northwestern Kings Canyon, and $\mathrm{C}$-Hill watersheds to $26 \mathrm{ft} / \mathrm{d}$ for sand and gravel in the Clear Creek watershed. Metamorphic bedrock beneath the watersheds commonly had clay-filled fractures or was largely weathered to clay with estimated geometric-mean hydraulic conductivities ranging from 0.02 to
$3.7 \mathrm{ft} / \mathrm{d}$. However, metamorphic rock about $40 \mathrm{ft}$ thick at the C-Hill watershed had a geometric-mean conductivity of $22 \mathrm{ft} / \mathrm{d}$. Geometric-mean hydraulic conductivities estimated for highly weathered granitic bedrock in the Clear Creek watershed were as low as $0.44 \mathrm{ft} / \mathrm{d}$ for a 20-ft thickness, but ranged from 3.1 to $20 \mathrm{ft} / \mathrm{d}$ for the remainder of the rock penetrated by test holes.

At the Clear Creek watershed, saturated basin-fill sediments, possibly more than $250 \mathrm{ft}$ thick, overlie weathered granitic bedrock that is friable and difficult to distinguish from the basin-fill sediments. At the C-Hill and northwestern Kings Canyon watersheds, about $60 \mathrm{ft}$ of saturated basin-fill sediments overlie metamorphic rocks having clay-filled fractures. At the Goni watershed, basin-fill sediments are unsaturated and saturated basaltic rocks about $220 \mathrm{ft}$ thick, including a cobble zone about $60 \mathrm{ft}$ thick with large conductivity, overlie metamorphic rock largely weathered to clay where fractured. At the Centennial Park watershed, basin-fill sediments beneath the cross section are mostly unsaturated, and about $70 \mathrm{ft}$ of saturated basaltic rocks overlie metamorphic rocks.

Subsurface flow estimated for the Clear Creek watershed using Darcy's law was 1,200 acre-ft/yr. This value may be low if more ground water flows (1) across the southern watershed/hydrographic area boundary or (2) at depths greater than that assumed permeable to flow beneath the cross section. The chloride-balance method was not used for the Clear Creek watershed where road salt is applied during winter months on U.S. Highway 50. Estimates of subsurface flow using Darcy's law and the chloride-balance method range from 20 to $70 \mathrm{acre}-\mathrm{ft} / \mathrm{yr}$ for the C-Hill watershed, from 600 to 2,300 acre- $\mathrm{ft} / \mathrm{yr}$ for the southeastern Kings Canyon watershed, from 20 to $150 \mathrm{acre}-\mathrm{ft} / \mathrm{yr}$ for the northwestern Kings Canyon watershed, from 200 to 500 acre-ft/yr for the Ash Canyon watershed, from 300 to $400 \mathrm{acre}-\mathrm{ft} / \mathrm{yr}$ for the Vicee Canyon watershed, from 70 to $400 \mathrm{acre}-\mathrm{ft} / \mathrm{yr}$ for the Goni watershed, and 20 to 30 acre-ft/yr for the Centennial Park watershed. Regressions of water yield show that the low estimate of subsurface flow for southeastern Kings Canyon may be the most reasonable value. The high estimate is based on Darcy's law, with a large amount of flow estimated through metamorphic rocks with open fractures. However, drilling for this study has shown that metamorphic rocks with open fractures are probably limited in extent.

Subsurface flow from uninstrumented watersheds was estimated by applying the percentage of annual precipitation represented by the range in subsurface 
flow for instrumented watersheds to nearby watersheds of similar geology. The estimate of subsurface flow from all watersheds tributary to Eagle Valley ranges from 3,200 to $6,100 \mathrm{acre}-\mathrm{ft} / \mathrm{yr}$, equivalent to a continuous flow of 4 to $8 \mathrm{ft}^{3} / \mathrm{s}$ at the perimeter of the valley floor.

Runoff measured by gaging stations for four watersheds and estimated runoff from other watersheds was combined with estimates of subsurface flow to obtain estimates of water yield. The estimate of water yield ranges from 12,000 to $15,000 \mathrm{acre}-\mathrm{ft} / \mathrm{yr}$; greater than a previous estimate of $9,000 \mathrm{acre}-\mathrm{ft} / \mathrm{yr}$. The previous estimate considered subsurface flow to be minimal, and is more representative of runoff alone.

The estimates of water yield represent 21-27 percent of the mean annual precipitation, with subsurface flow totaling 6-11 percent, and runoff totaling 16 percent. Therefore, 73-79 percent of the precipitation that falls on the watersheds is lost to evaporation or transpiration.

Of the total water yield, basin-fill aquifers beneath Eagle Valley are recharged by subsurface flow and surface runoff from each watershed that infiltrates to the water table as streams cross alluvial fans. Part of the total water yield is lost on the valley floor to evaporation and transpiration by plants, and part leaves the hydrographic area as surface-water flow to the Carson River or subsurface ground-water flow beneath the boundary of the hydrographic area.

The annual volume of precipitation and surface runoff, and average water yield estimated for each instrumented watershed was divided by the area to obtain mean rates in inches per year. Mean water yield and runoff for each watershed were regressed against mean precipitation to develop equations predicting water yield and surface runoff for watersheds tributary to Eagle Valley. The equations predicting water yield and runoff have $\mathrm{r}^{2}$ values of 0.93 and 0.91 , respectively. Additional estimates of water yield and runoff from nearby hydrographic areas would allow refinement of these equations, which might then be applied to other areas along the eastern slope of the Sierra Nevada.

\section{REFERENCES CITED}

Alger, R.P., 1966, Interpretation of electric logs in fresh water wells in unconsolidated formations: Seventh Annual Logging Symposium, Society of Professional Well Log Analysts, Tulsa, Okla., Transactions, p. CClCC25.
Archie, G.E., 1942, The electrical resistivity $\log$ as an aid in determining some reservoir characteristics: Transactions of the Society of Petroleum Engineers of the American Institute of Mining, Metallurgical and Petroleum Engineers, v. 146, p. 54-62.

Arteaga, F.E., 1986, Mathematical model analysis of the Eagle Valley ground-water basin, west-central Nevada: Nevada Division of Water Resources Bulletin 45, 53 p.

Arteaga, F.E., and Durbin, T.J., 1979, Development of a relation for steady-state pumping rate for Eagle Valley ground-water basin, Nevada: U.S. Geological Survey Open-File Report 79-261, 44 p.

Berger, D.L., Ross, W.C., Thodal, C.E., and Robledo, A.R., 1997, Hydrogeology and simulated effects of urban development on water resources of Spanish Springs Valley, Washoe County, west-central Nevada: U.S. Geological Survey Water-Resources Investigations Report 96-4297, 80 p.

Bingler, E.C., 1977, Geologic map, New Empire quadrangle: Nevada Bureau of Mines and Geology, Map 59, scale 1:24,000.

Bouwer, Herman, and Rice, R.C., 1976, A slug test for determining the hydraulic conductivity of unconfined aquifers with completely or partially penetrating wells: Water Resources Research, v. 12, no. 3, p. 423-428.

Cardinalli, J.L., Roach, L.M., Rush, F.E., and Vasey, B.J., comps., 1968, State of Nevada hydrographic areas: Nevada Division of Water Resources map, scale 1:500,000.

Croft, M.G., 1971, A method of calculating permeability from electric logs, in Geological Survey Research 1971: U.S. Geological Survey Professional Paper 750B, p. B265-B269.

Dettinger, M.D., 1989, Reconnaissance estimates of natural recharge to desert basins in Nevada, U.S.A., by using chloride-balance calculations: Journal of Hydrology, v. 106 , no. $1 / 2$, p. $55-78$.

Freeze, R.A., and Cherry, J.A., 1979, Groundwater: Englewood Cliffs, N.J., Prentice-Hall, 604 p.

Hardy, M.A., Leahy, P.P., and Alley, W.M., 1989, Well installation and documentation, and ground-water sampling protocols for the pilot National Water-Quality Assessment Program: U.S. Geological Survey OpenFile Report 89-396, 36 p.

Heath, R.C., 1989, Basic ground-water hydrology: U.S. Geological Survey Water-Supply Paper 2220, 84 p.

Kattleman, Richard, and Elder, Kelly, 1991, Hydrologic characteristics and water balance of an alpine basin in the Sierra Nevada: Water Resources Research, v. 27, no. 7, p. 1553-1562.

Kipp, K.L., Jr., 1985, Type curve analysis of intertial effects in the response of a well to a slug test: Water Resources Research, v. 21, no. 9, p. 1397-1408. 
Kwader, T.K., 1985, Estimating aquifer permeability from formation resistivity factors: Groundwater, v. 23 , no. 6 , p. $762-766$.

Marks, Danny, Dozier, Jeff, and Davis, R.E., 1992, Climate and energy exchange at the snow surface in the alpine region of the Sierra Nevada 1. Meteorological measurements and monitoring: Water Resources Research, v. 28 , no. 211 , p. $3029-3042$.

Maurer, D.K., Berger, D.L., and Prudic, D.E., 1996, Subsurface flow to Eagle Valley from Vicee, Ash, and Kings Canyons, Carson City, Nevada, estimated from Darcy's Law and the chloride-balance method: U.S. Geological Survey Water-Resources Investigations Report 964088, $74 \mathrm{p}$.

Moore, D.O., 1968, Estimating mean runoff in ungaged semiarid areas: Nevada Department of Conservation and Natural Resources, Water Resources Bulletin 36, $11 \mathrm{p}$.

Moore, J.G., 1969, Geology and mineral deposits of Lyon, Douglas, and Ormsby Counties, Nevada: Nevada Bureau of Mines Bulletin 75, 45 p.

Neuman, S.P., 1982, Statistical characterization of aquifer heterogeneities-An overview, in Narasimhan, T.N., ed., Recent trends in hydrogeology: Geological Society of America Special Paper 189, p. 81-102.
Owenby, J.R., and Ezell, D.S., 1992, Monthly station normals of temperature, precipitation, and heating and cooling degree days 1961-1990, Nevada: National Climatic Data Center, Climatography of the United States, no. $81,20 \mathrm{p}$.

Pease, R.C., 1980, Geologic map, Genoa quadrangle: Nevada Bureau of Mines and Geology, Urban Map Series Genoa Folio, Map 1Cg, scale 1:24,000.

Rush, F.E., 1968, Index of hydrographic areas in Nevada: Nevada Division of Water Resources, Information Report 6, $38 \mathrm{p}$.

Shelton, L.R., 1994, Field guide for collecting and processing stream-water samples for the National Water-Quality Assessment Program: U.S. Geological Survey Open-File Report 94-455, 42 p.

Trexler, D.T., 1977, Geologic map, Carson City quadrangle: Nevada Bureau of Mines and Geology Urban Map Series, Carson City Folio, Map 1Ag, scale 1:24,000.

Trexler, D.T., Koenig, B.A., Flynn, Thomas, and Bruce, J.L., 1980, Assessment of the geothermal resources of Carson-Eagle Valleys and Big Smoky Valley, Nevada First annual report: Nevada Bureau of Mines and Geology report DOE/NV/10039-2, $162 \mathrm{p}$.

Worts, G.F., Jr., and Malmberg, G.T., 1966, Hydrologic appraisal of Eagle Valley, Ormsby County, Nevada: Nevada Department of Conservation and Natural Resources, Water Resources Reconnaissance Report $39,55 \mathrm{p}$. 


\section{Appendix 1. \\ Borehole Geophysical and Lithologic Data}




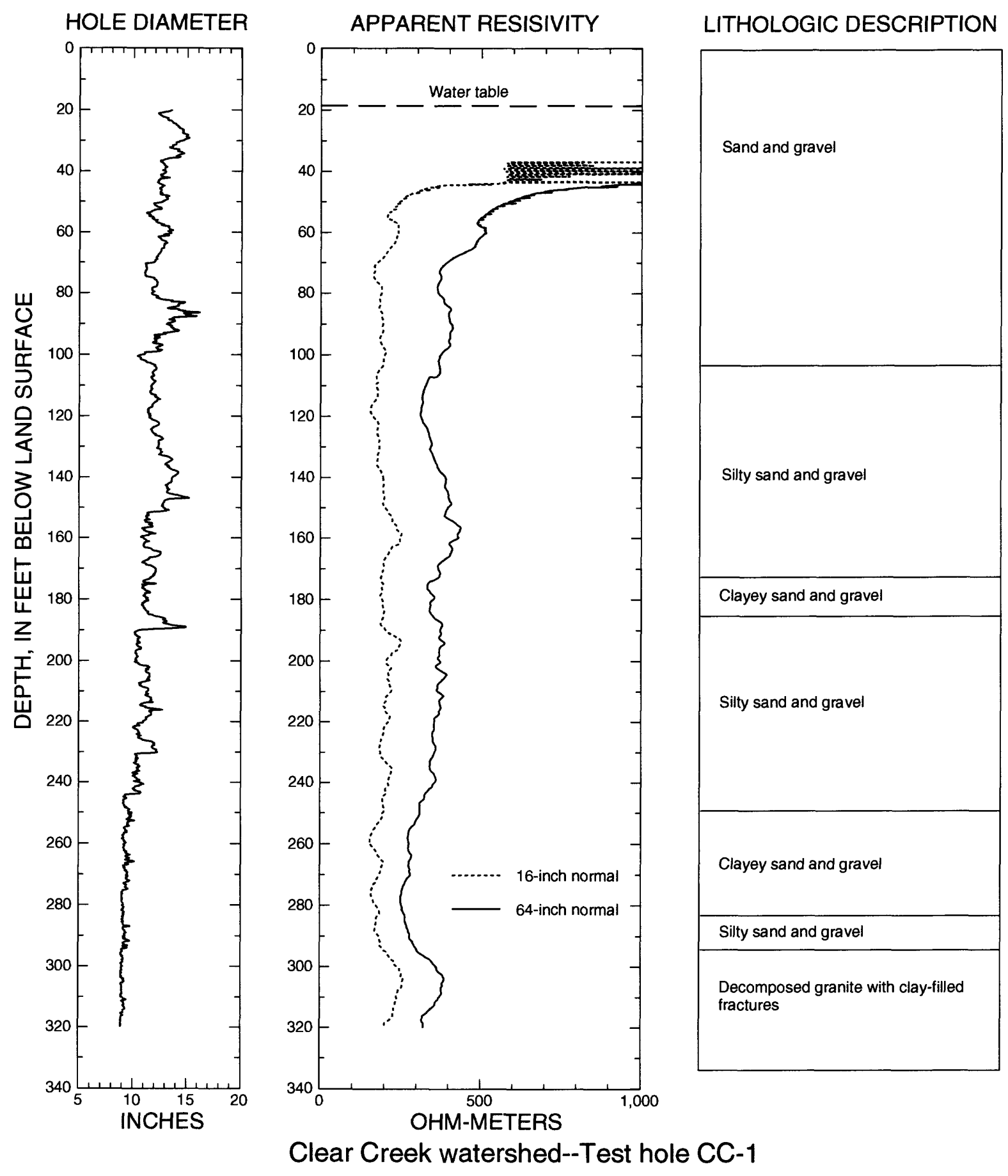




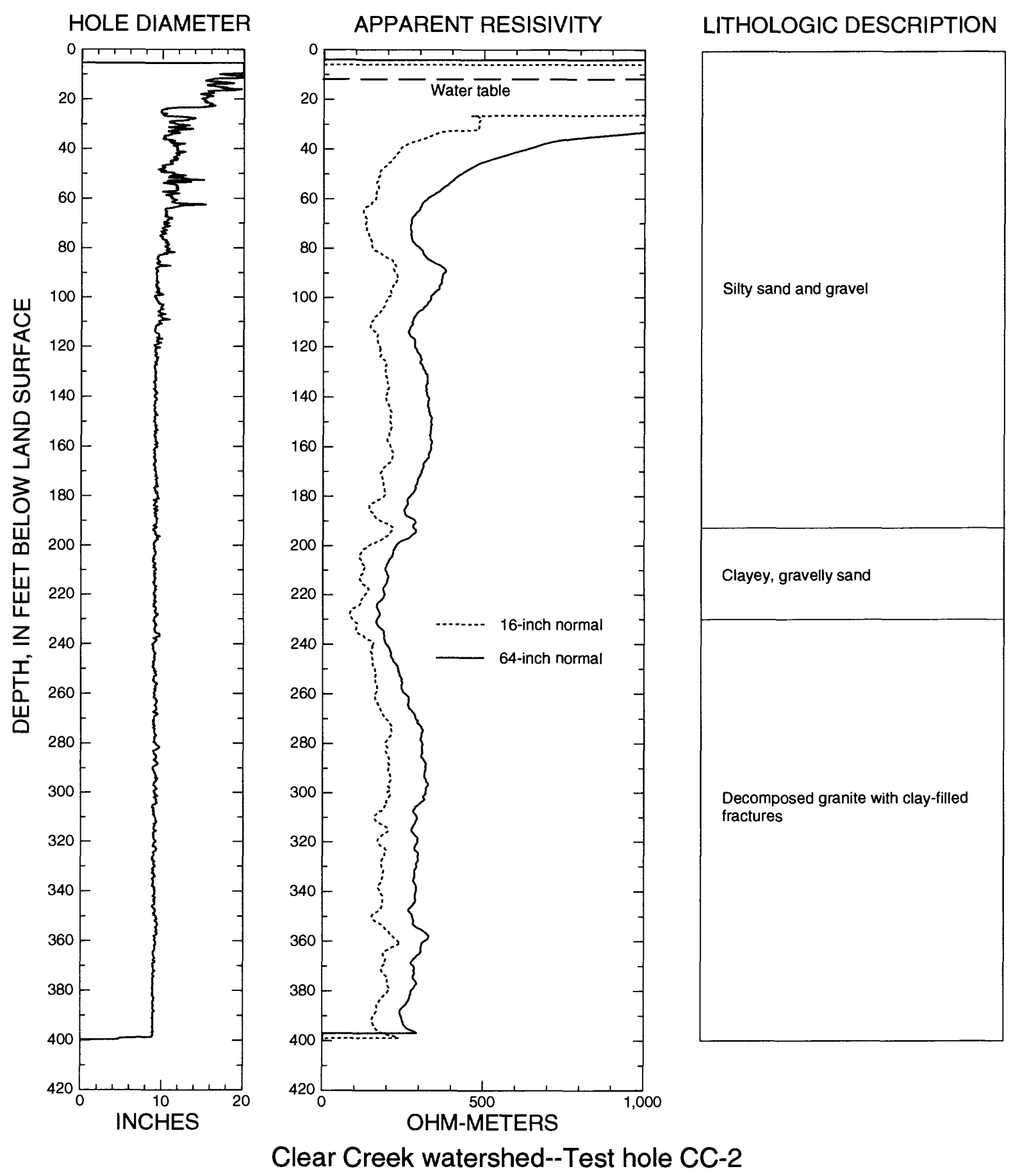



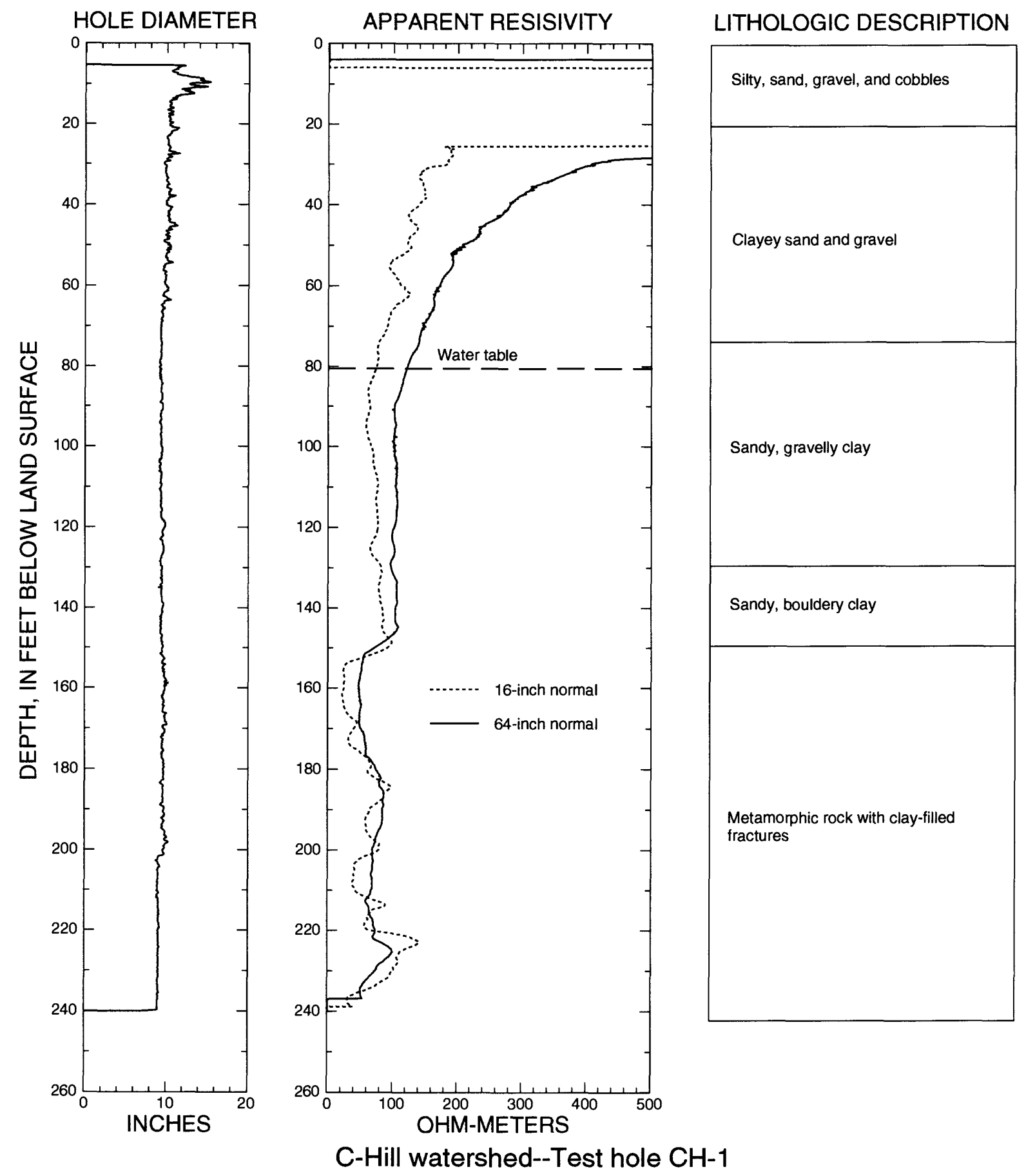

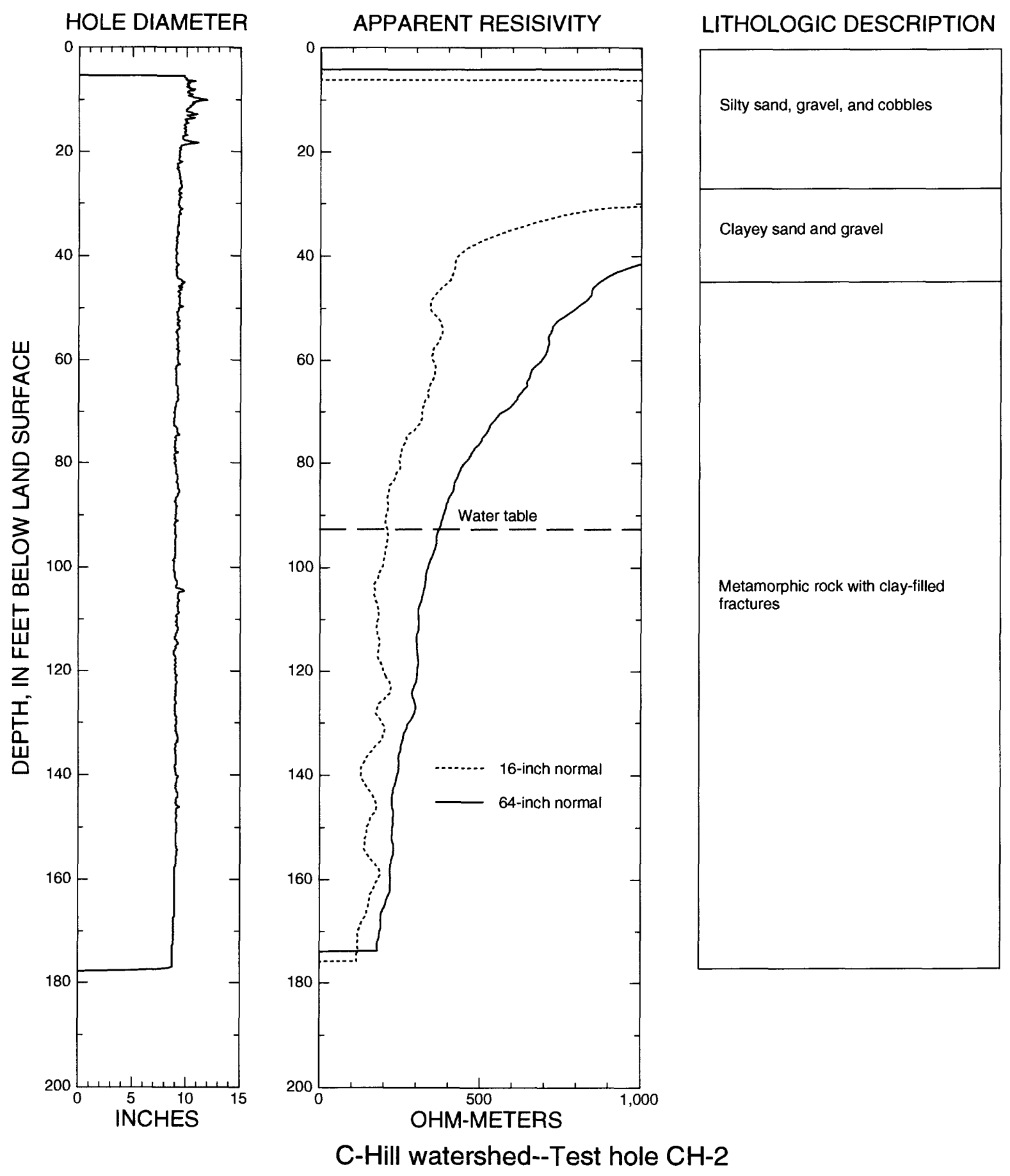


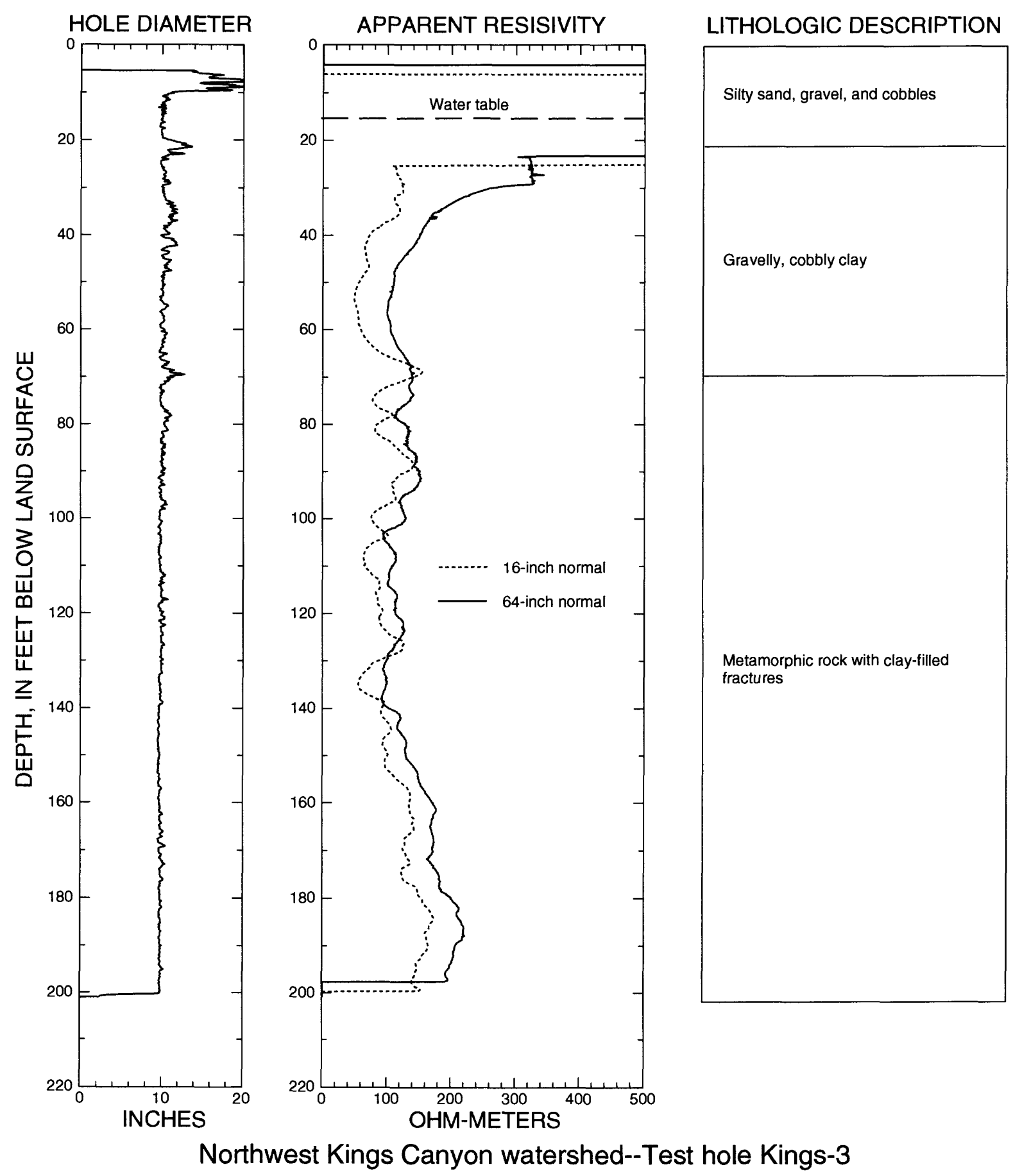



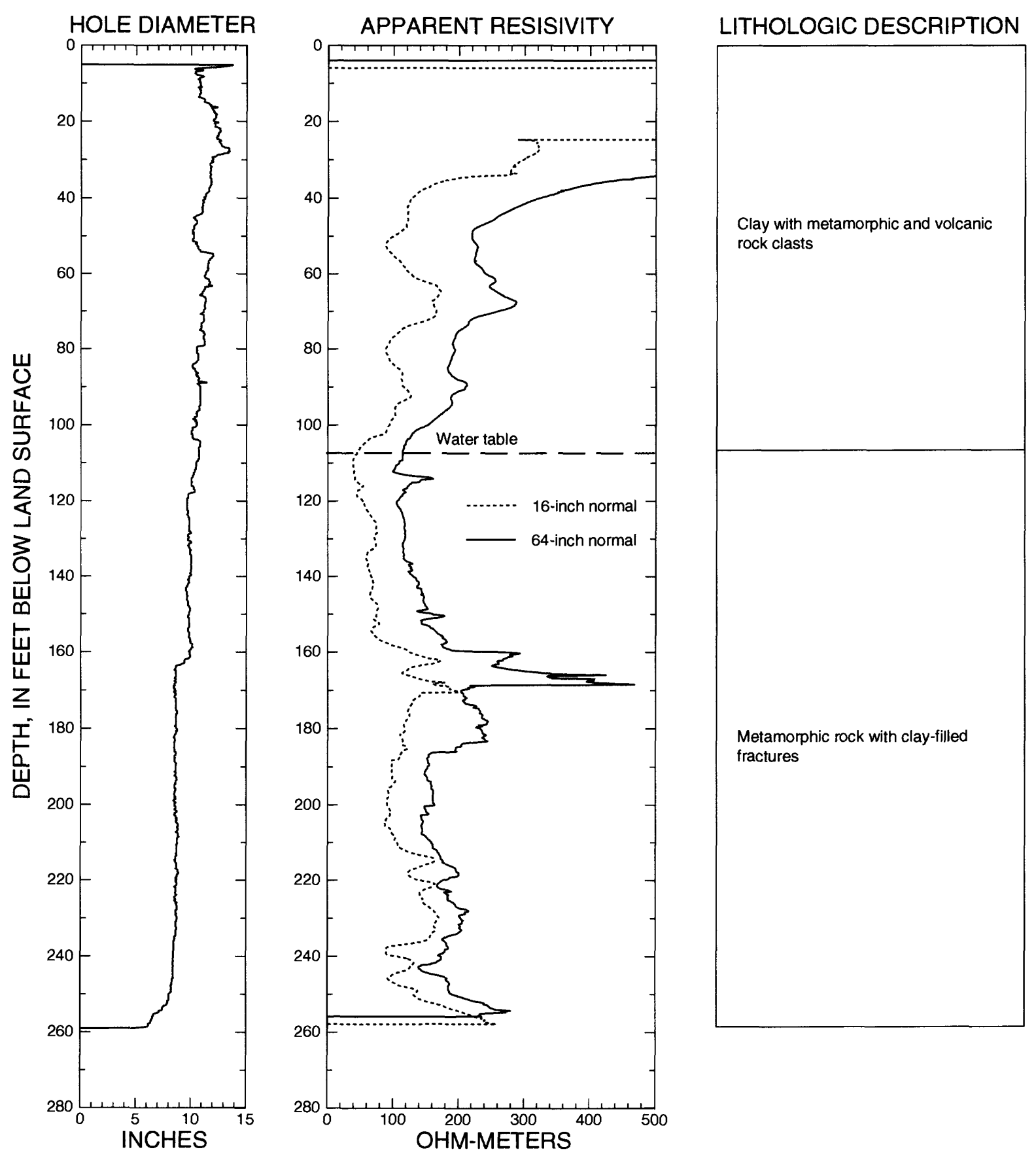

Goni watershed--Test hole Goni-2 

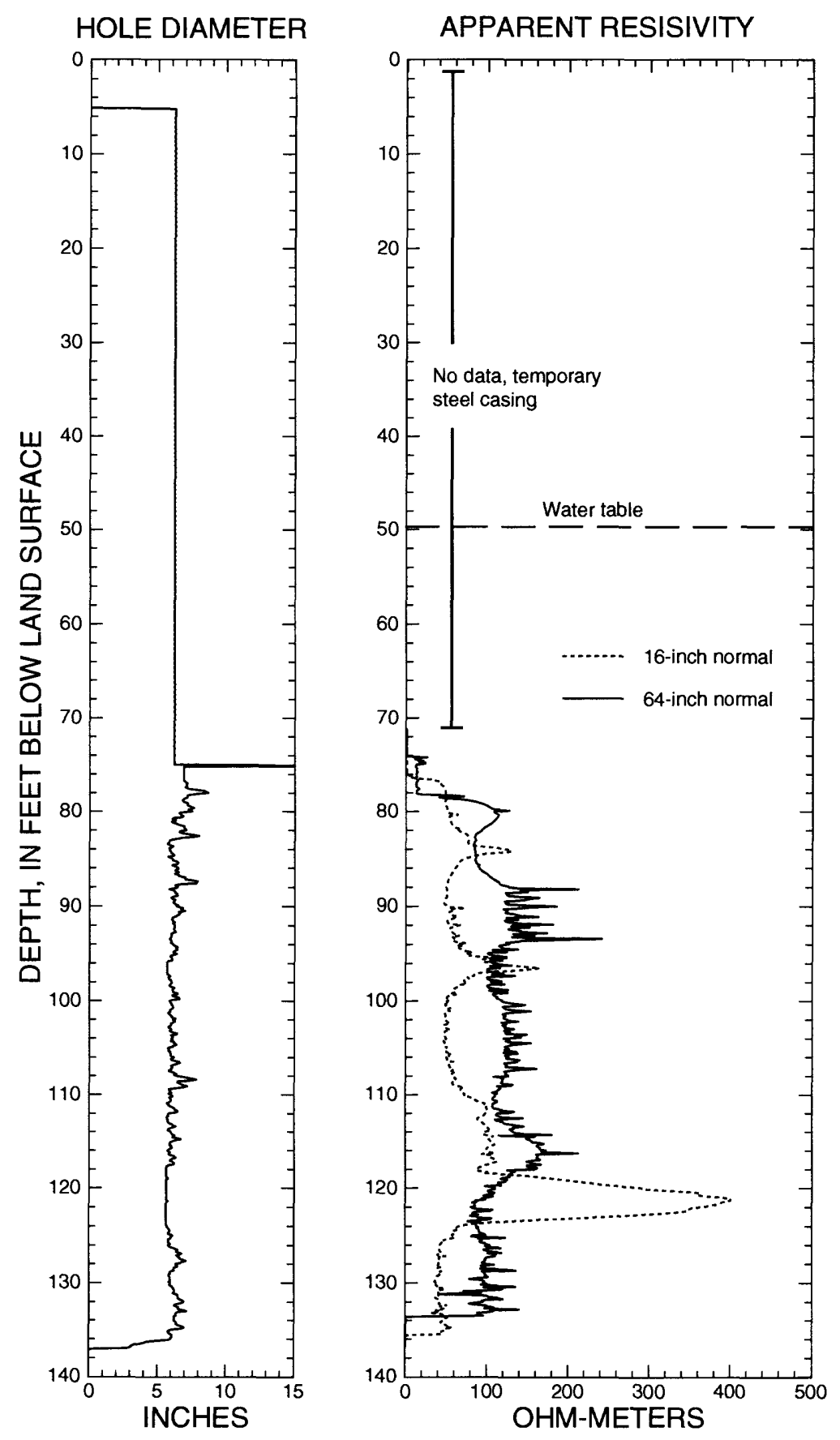

LITHOLOGIC DESCRIPTION

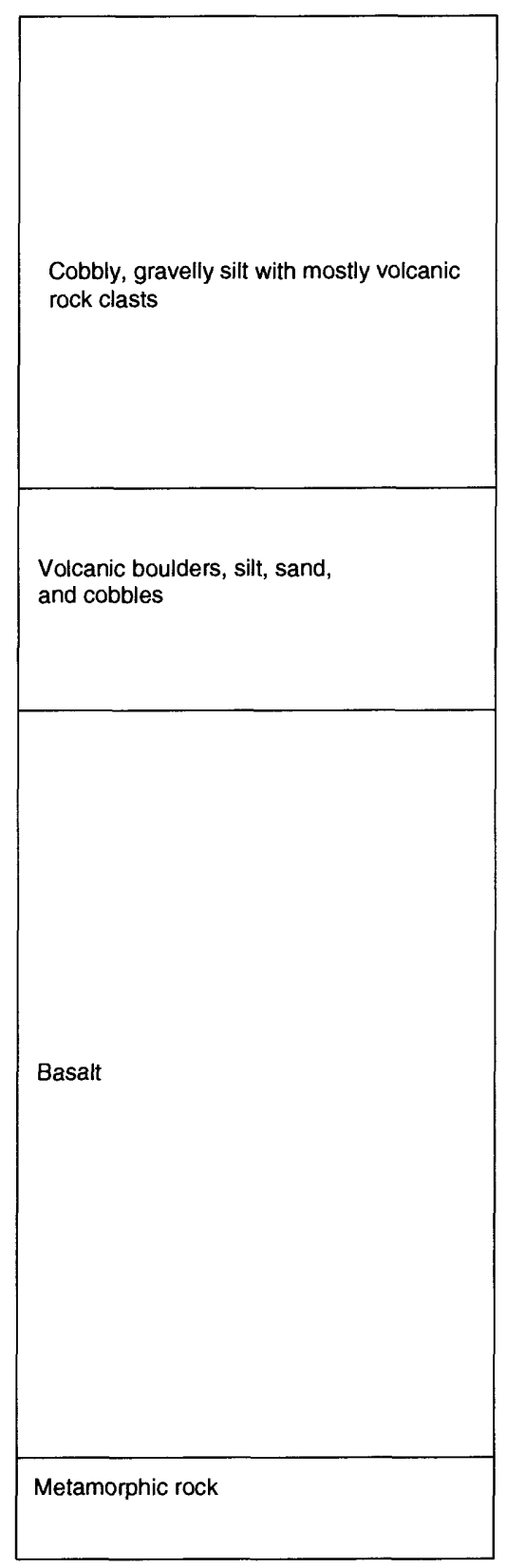

Centennial Park test well 


\section{Appendix 2. \\ Well Location, Construction, and Water-Level Data}




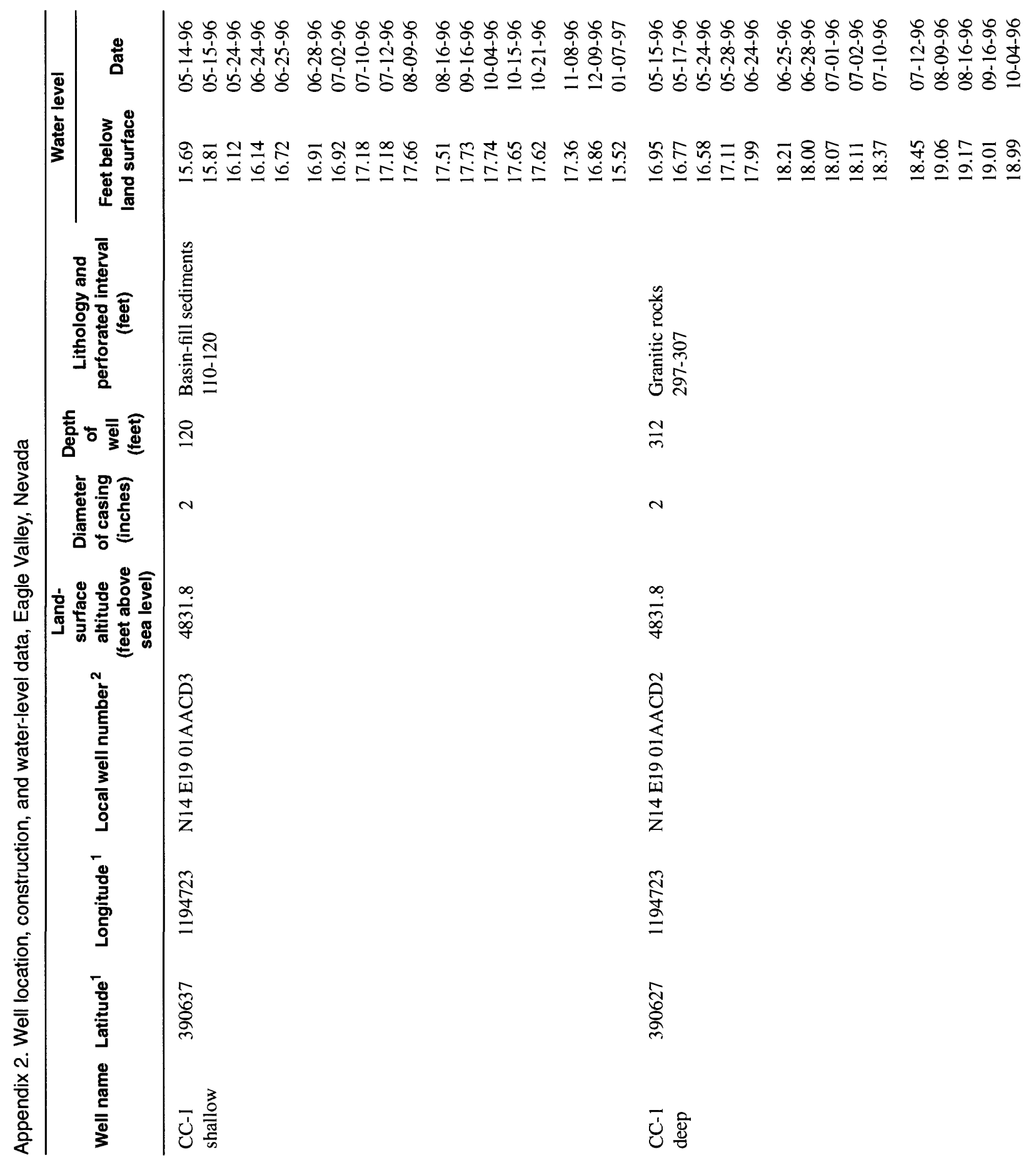




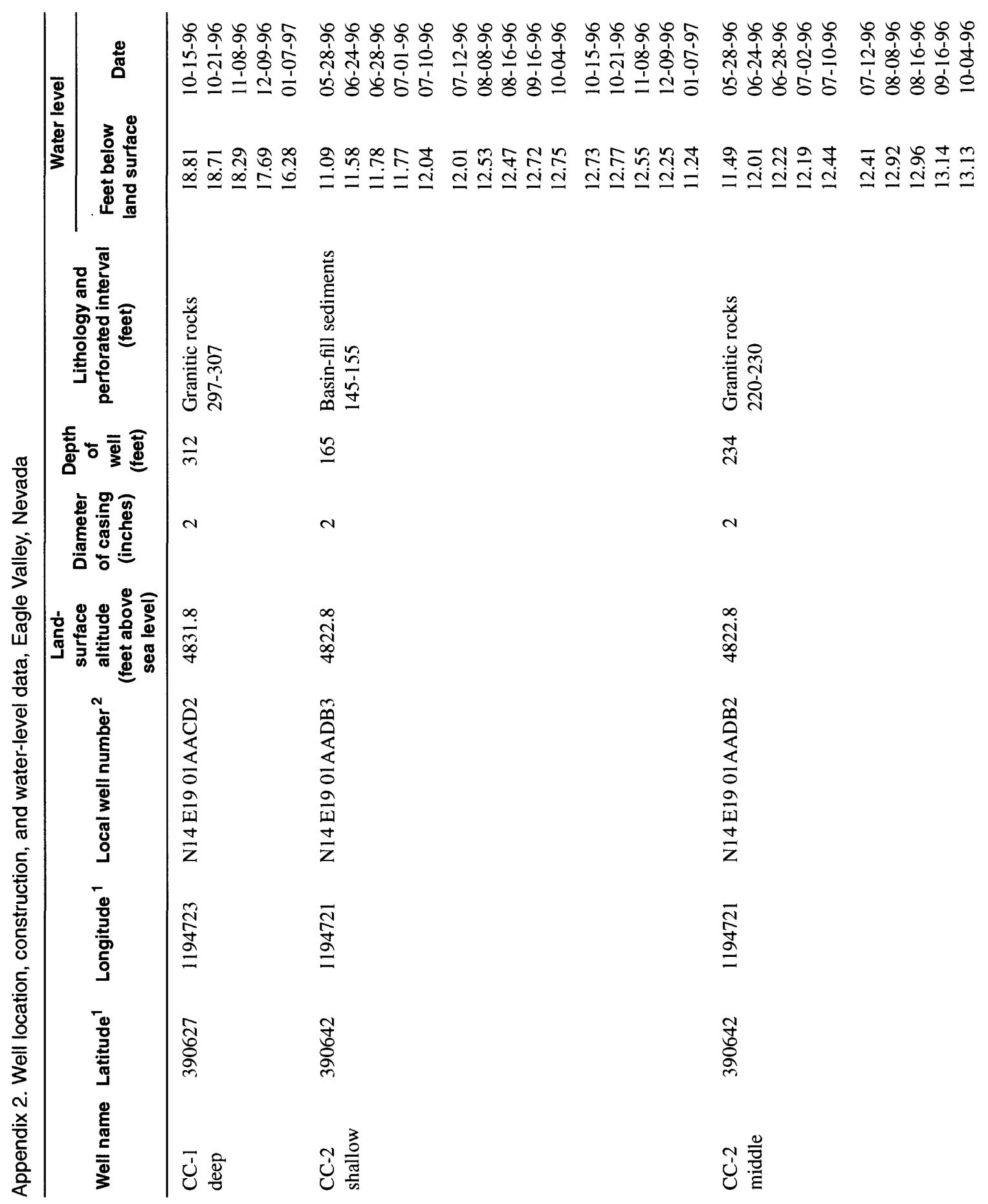




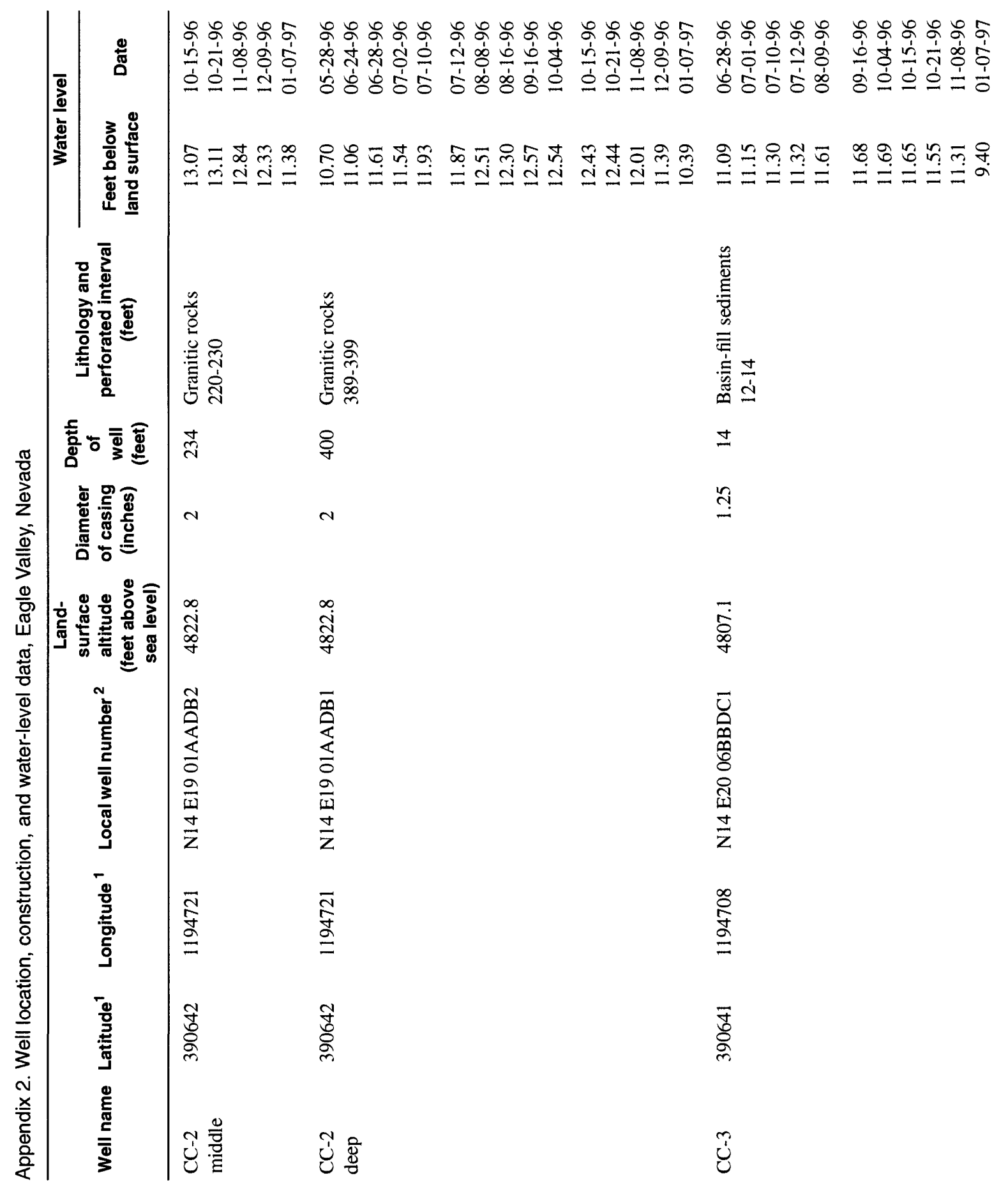




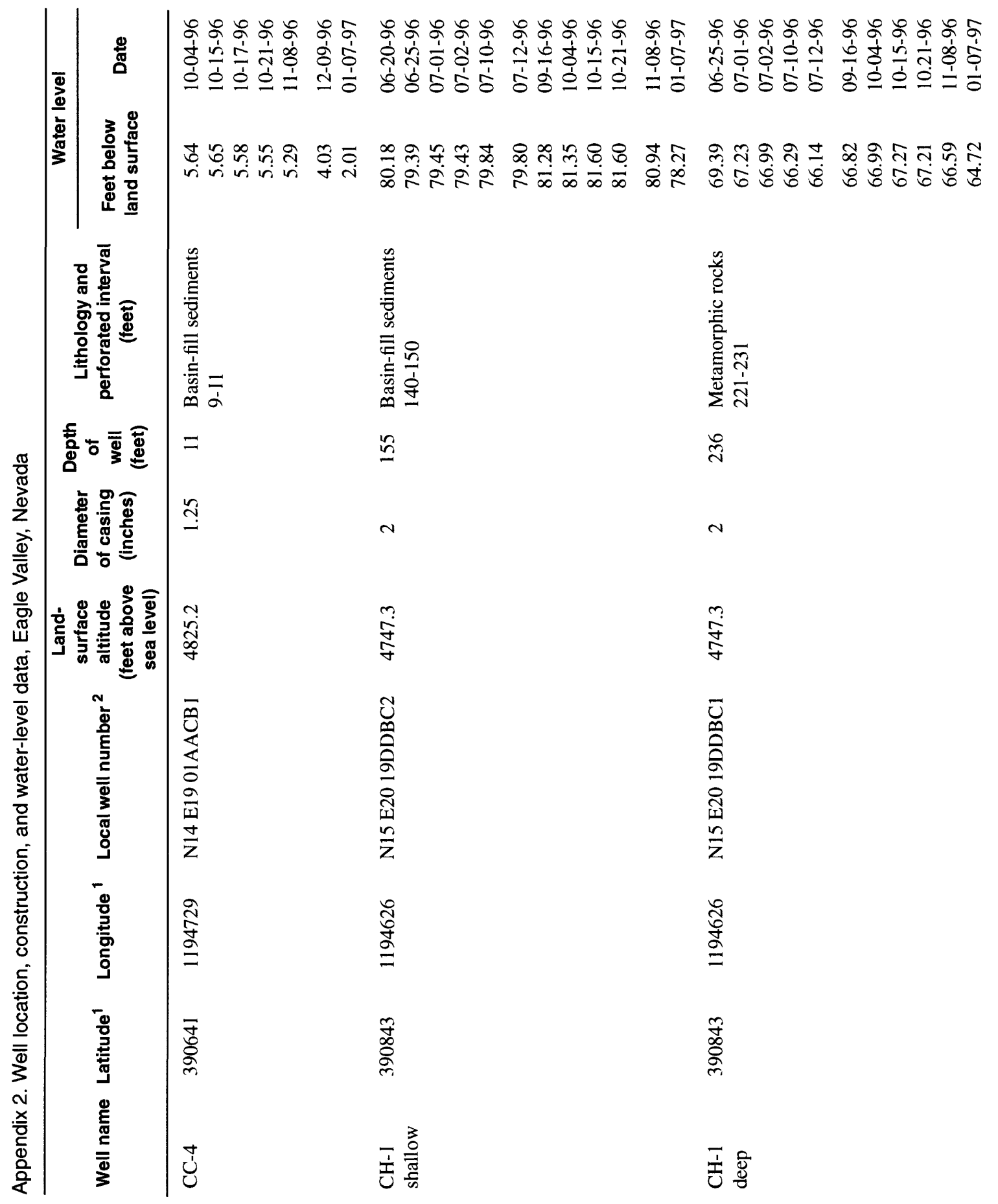




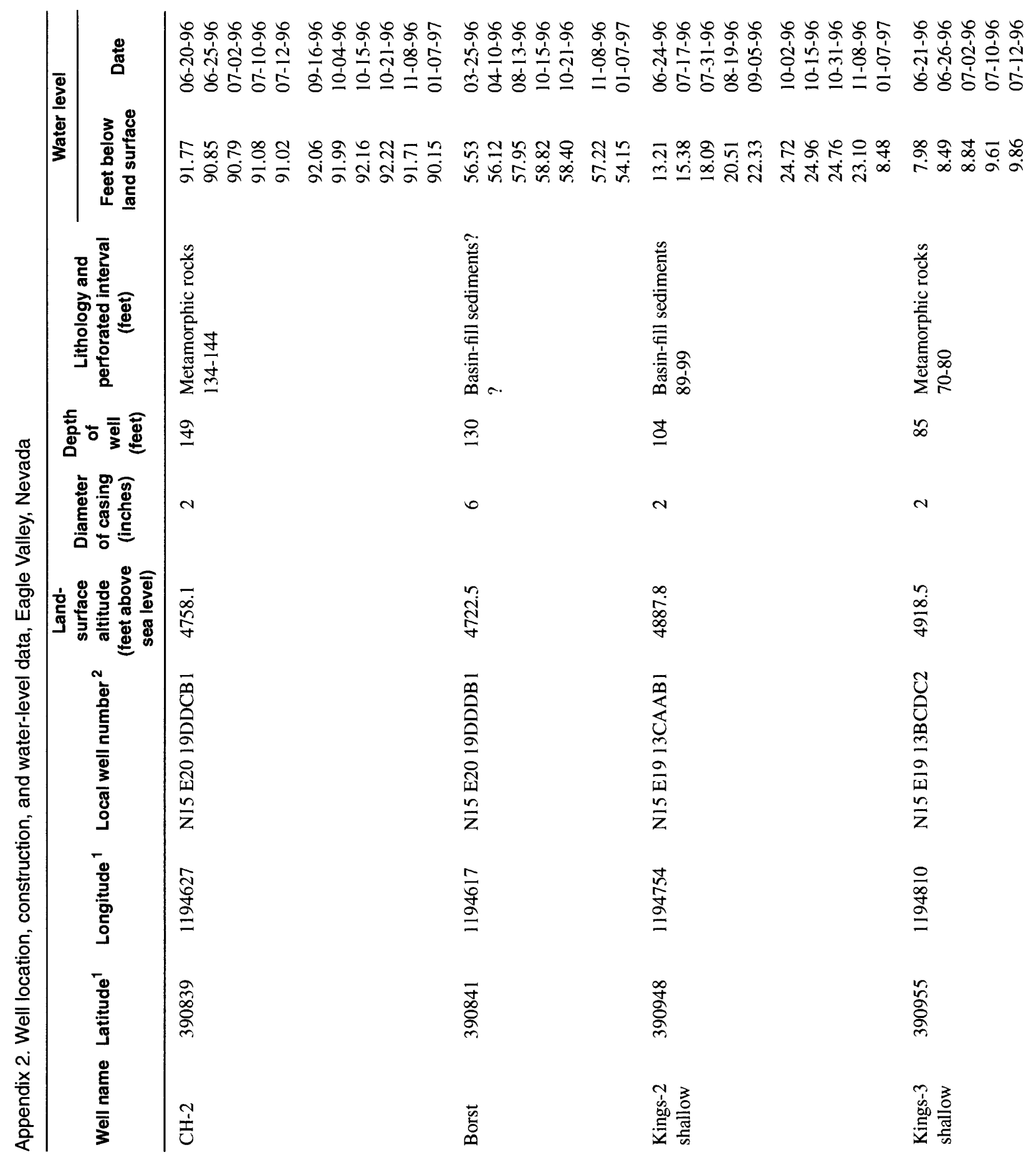




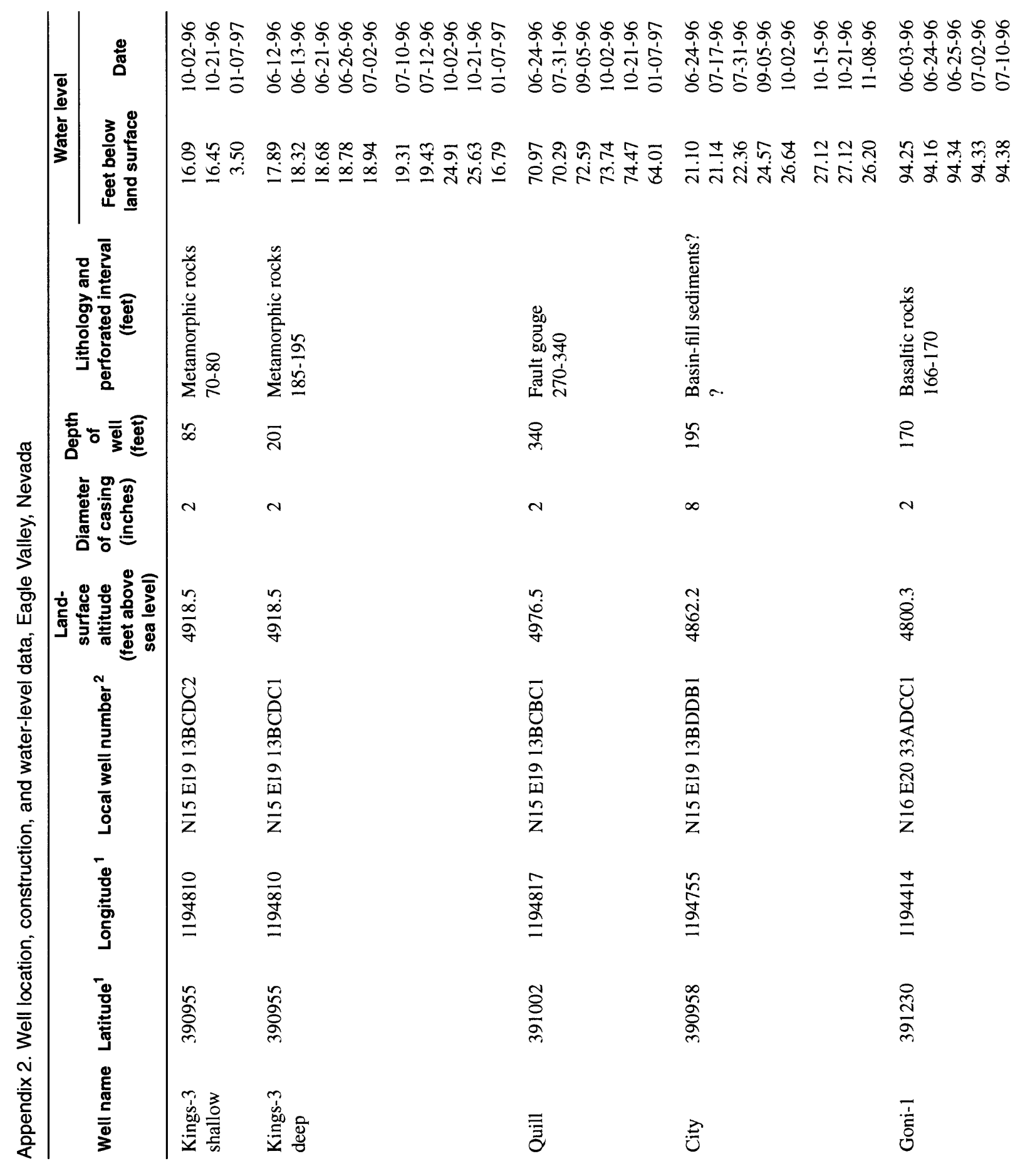




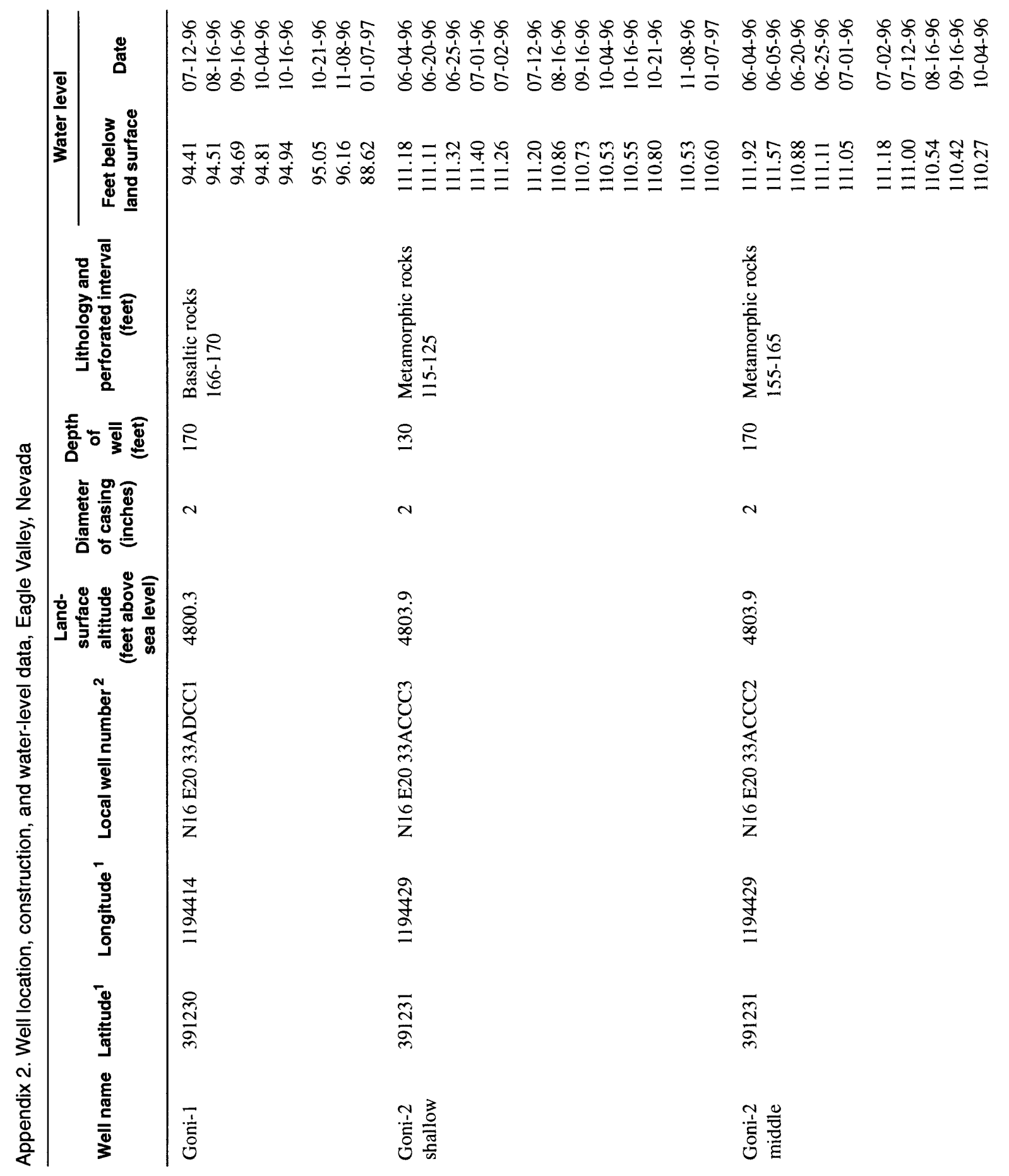




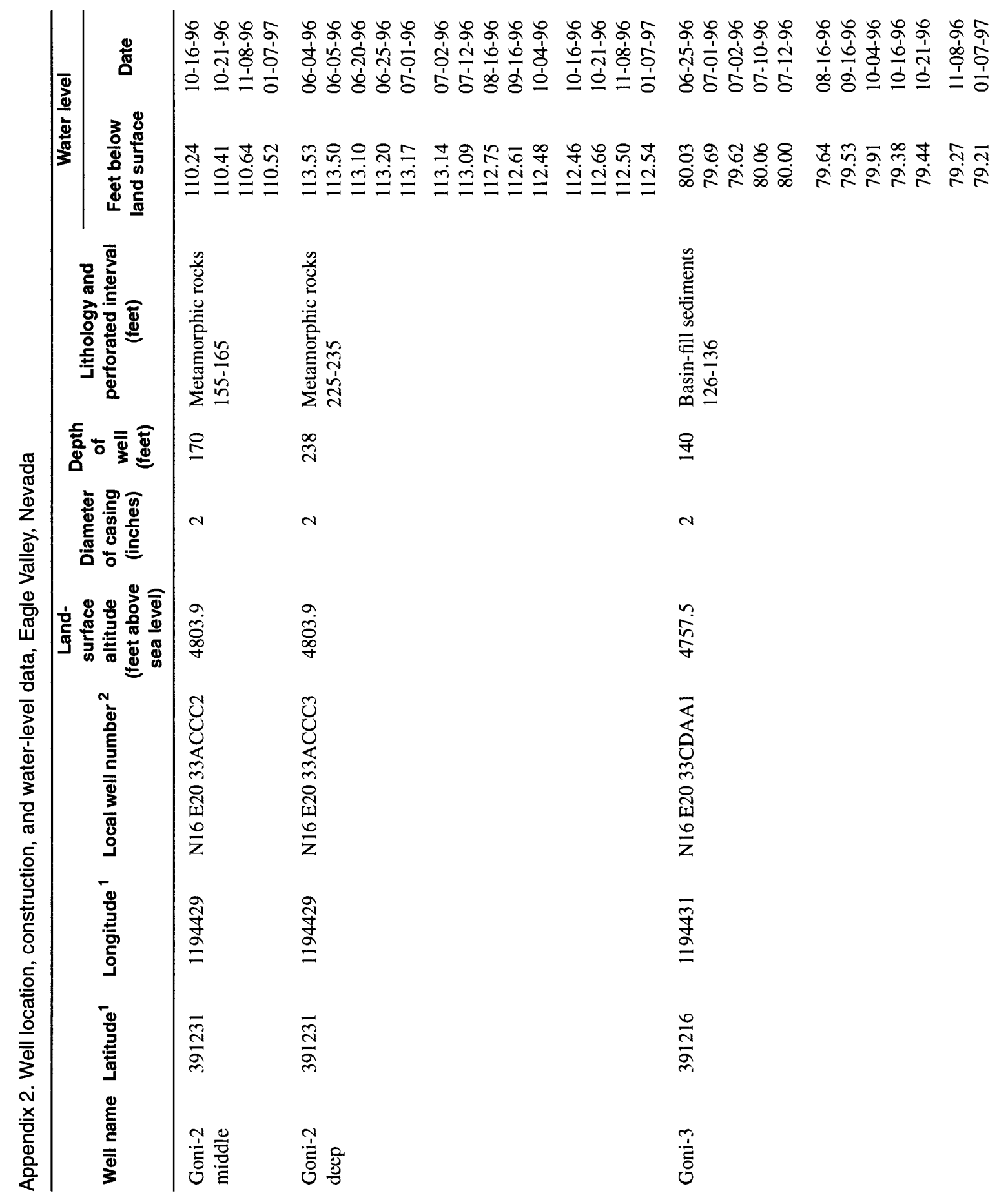




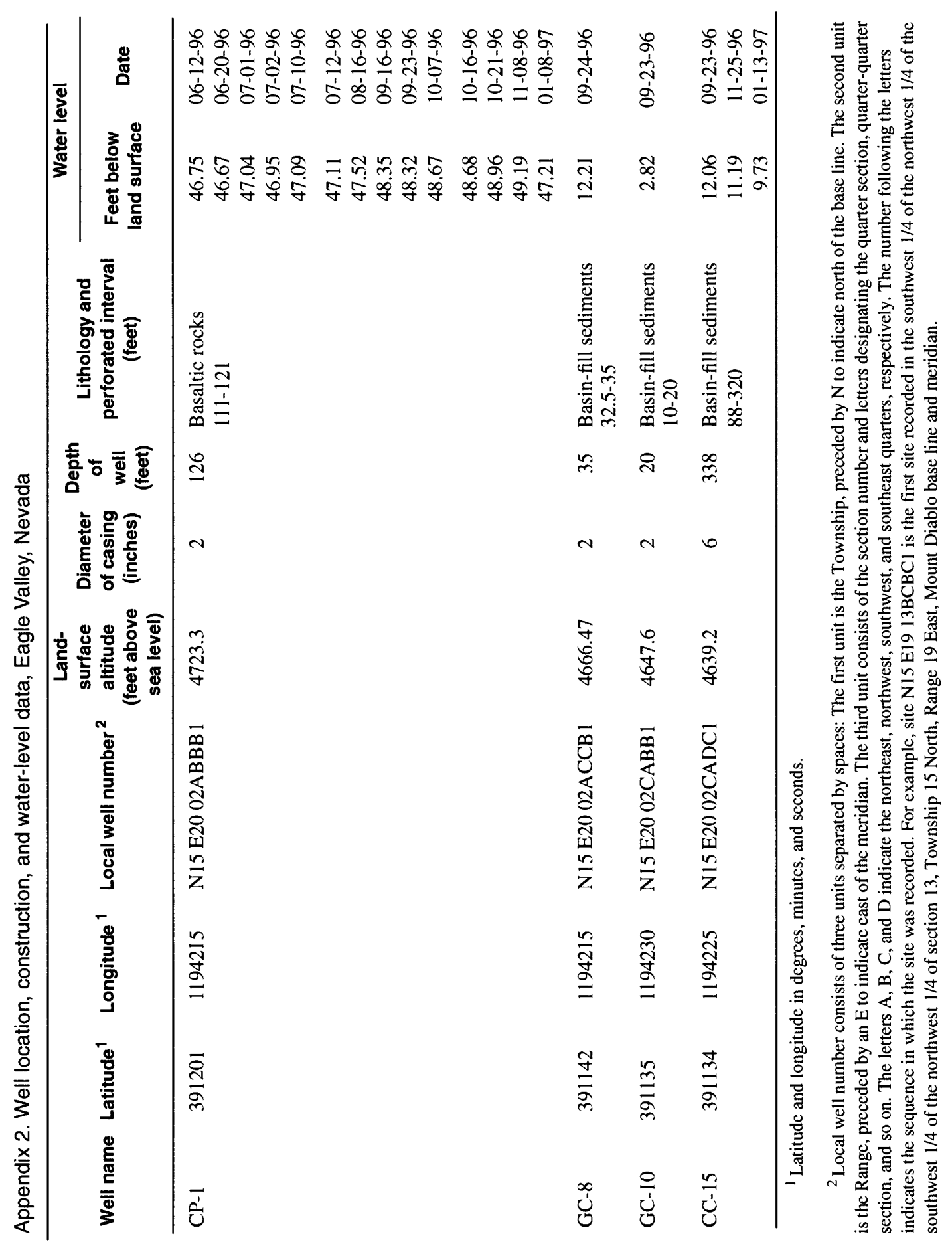




\section{CONTRIBUTING U.S. GEOLOGICAL SURVEY STAFF}

\section{TECHNICAL REVIEWERS}

Carol J. Boughton, Hydrologist

Glen W. Hess, Hydrologist

Ray J. Hoffman, Hydrologist

William D. Nichols, Hydrologist

David E. Prudic, Hydrologist

Patrick Tucci, Hydrologist

DATA-COLLECTION SUPPORT

Carl E. Thodal, Hydrologist

James L. Wood, Hydrologic Technician

\section{PUBLICATIONS SUPPORT}

Shannon C. DeMeo, Editorial Assistant James M. Lamoreux, Scientific Illustrator Rose L. Medina, Physical Scientist

Robin L. Sweet, Technical Editor

Albert S. VanDenburgh, Reports Specialist

WESTERN REGION DRILL RIG SUPPORT

Jack E. Hennagan, Drill Rig Operator James L. Huckaby, Drill Rig Operator Raymond M. McKean, Drill Rig Operator 